DENICAR LINA NASCIMENTO FABRIS

EFEITOS ADJUVANTES DE DERIVADOS DA TOXINA TERMO-

LÁBIL DE ESCHERICHIA COLI (LT1) NA RESPOSTA DE

ANTICORPOS ESPECÍFICOS VOLTADOS PARA O DOMÍNIO III DA

GLICOPROTEÍNA E DO VÍRUS DENGUE TIPO 2 (DENV2)

Dissertação apresentada ao Programa de PósGraduação em Biologia da Relação PatógenoHospedeiro do Instituto de Ciências Biomédicas da Universidade de São Paulo, para obtenção do título de Mestre em Ciências.

São Paulo

2014 
DENICAR LINA NASCIMENTO FABRIS

\section{EFEITOS ADJUVANTES DE DERIVADOS DA TOXINA TERMO- LÁBIL DE ESCHERICHIA COLI (LT1) NA RESPOSTA DE ANTICORPOS ESPECÍFICOS VOLTADOS PARA O DOMÍNIO III DA GLICOPROTEÍNA E DO VÍRUS DENGUE TIPO 2 (DENV2)}

Dissertação apresentada ao Departamento de Parasitologia do Instituto de Ciências Biomédicas da Universidade de São Paulo, para obtenção do título de Mestre em ciências.

Área de concentração: Biologia da Relação Patógeno-Hospedeiro.

Orientador: Prof. Dr. Luís Carlos de Souza Ferreira

Versão corrigida. A versão original eletrônica encontra-se disponível tanto na Biblioteca do ICB quanto na Biblioteca Digital de Teses e Dissertações da USP (BDTD). 
DADOS DE CATALOGAÇÃO NA PUBLICAÇÃO (CIP)

Serviço de Biblioteca e Informação Biomédica do

Instituto de Ciências Biomédicas da Universidade de São Paulo

reprodução não autorizada pelo autor

Fabris, Denicar Lina Nascimento.

Efeitos adjuvantes de derivados da toxina termo-lábil de Escherichia coli (LT1) na resposta de anticorpos específicos voltados para o domínio III da glicoproteína E do vírus dengue tipo 2 (DENV2) / Denicar Lina Nascimento Fabris. -- São Paulo, 2014.

Orientador: Prof. Dr. Luis Carlos de Souza Ferreira.

Dissertação (Mestrado) - Universidade de São Paulo. Instituto de Ciências Biomédicas. Departamento de Parasitologia. Área de concentração: Biologia da Relação Patógeno-Hospedeiro. Linha de pesquisa: Imunidade adaptativa a infecções e desenvolvimento de vacinas.

Versão do título para o inglês: Adjuvant effects of Escherichia coli thermo-labile toxin (LT1) derivatives in the specific antibody response directed to the $\mathrm{E}$ glycoprotein domain III of type 2 dengue virus (DENV2).

1. Toxina termo-lábil 2. Adjuvante 3. Vacina 4. Resposta humoral 5. Vírus dengue 6. Glicosilação de anticorpo I. Ferreira, Prof. Dr.Luis Carlos de Souza II. Universidade de São Paulo. Instituto de Ciências Biomédicas. Programa de Pós-Graduação em Biologia da Relação Patógeno-Hospedeiro III. Título. 
Candidato(a):

Título da Dissertação:

Orientador(a):
Denicar Lina Nascimento Fabris.

Efeitos adjuvantes de derivados da toxina termo-lábil de Escherichia coli (LT1) na resposta de anticorpos específicos voltados para o domínio III da glicoproteína $\mathrm{E}$ do vírus dengue tipo 2 (DENV2).

Prof. Dr. Luís Carlos de Souza Ferreira.

A Comissão Julgadora dos trabalhos de Defesa da Dissertação de Mestrado, em sessão pública realizada a ......... considerou
( ) Aprovado(a)
( ) Reprovado(a)

Examinador(a): Assinatura:

Nome:

Instituição:

Examinador(a): Assinatura:

Nome:

Instituição:

Presidente: Assinatura:

Nome:

Instituição: 


\section{Certificado}

Certificamos que o protocolo registrado sob n 198 nas fls. 116 do livro 02 para uso de animais em experimentação, sob a responsabilidade do Prof(a) Dr(a)) Luis Carlos de Souza Ferreira, Coordenador (a) da Linha de pesquisa "Efeitos adjuvantes de derivados da toxina termo-lábil de Escherichia coli (LT1) na resposta de anticorpos específicos voltados para o domínio III da glicoproteína $E$ do Vírus dengue tipo 2 (DENV2)" do qual participam o(s) aluno(s) Denicar Lina Nascimento Fabris, Jaime Henrique Amorim e os pesquisadores Juliana Falcão Rodrigues, Sandriana R. da Silva, Eliana Faquim de Lima Mauro,, está de acordo com os Princípios Éticos de Experimentação Animal adotado pela Sociedade Brasileira de Ciência de Animais de Laboratório (SBCAL) e foi aprovado pela COMISSÃO DE ÉTICA NO USO DE ANIMAIS (CEUA) em 08.12.2011, com validade de 4 anos.

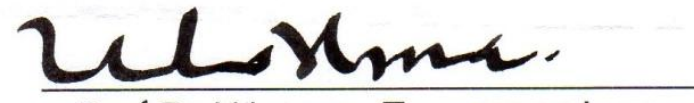

Prof.Dr.WOTHAN TAVARES DE LIMA

Coordenador

CEUA - ICB/USP

São Paulo, 09 de dezembro de 2011.

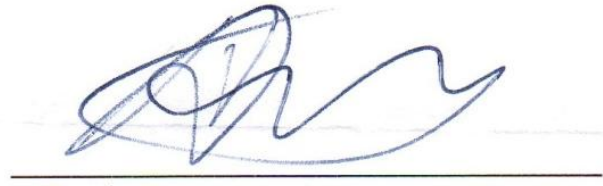

Prof. Dr. ARIEL MARIANO SILBER Secretário CEUA - ICB/USP 
Dedico este trabalho

À minha família, Por todo o apoio, dedicação e carinho. Ao Vitor, minha vida que amo muito, Pelo companheirismo e compreensão.

E a Deus, meu Senhor e guia, Proporcionando muitas conquistas, Tornando os meus sonhos possíveis. 


\section{AGRADECIMENTOS}

Essa dissertação é resultado de muito esforço e dedicação não apenas por mim, mas também pela união de diversas colaborações e parcerias. Meus sinceros agradecimentos:

Ao prof. Luís, pela orientação, confiança e ensinamentos no caminho da ciência, possibilitando a realização deste trabalho.

À co-orientação da pesquisadora Dra. Juliana Falcão Rodrigues, por sua paciência, amizade, dedicação e por incentivar a prosseguir nos momentos difíceis. Ju muito obrigada!

À colaboração da pesquisadora Dra. Sandriana Ramos, pela determinação, dedicação e amizade, animação, e por sempre estar disposta a ajudar. San muito obrigada!

À colaboração do pesquisador Dr. Jaime Amorim, pelos seus ensinamentos, ajuda nos momentos difíceis e sempre estar disposto a ensinar. Muito Obrigada!

À colaboração da profa. Eliana Faquim, pelos ensinamentos e por disponibilizar seu laboratório para a realização de parte deste trabalho.

Ao prof. José Osvaldo Previato, por me receber de braços abertos em seu laboratório, por toda a compreensão e ensinamentos.

À Mariana Cintra, Naomi Nakao, por me fazer companhia, pelos ensinamentos, amizade, dedicação, compromisso e por sempre estarem disposta a ajudar.

À colaboração da Ms. Camila Santos, por toda a ajuda, disposição e dedicação.

À minha amiga Raíza, pela compreensão, dedicação, preocupação e por disponibilizar momentos de muita alegria.

À profa. Rita por me aceitar no laboratório e sempre confiar no meu trabalho. 
Aos colegas, Bruna, Marcinha, Cariri, Mari Diniz, Renatinha, Natiely, Jamile, Milene, Rafael, Aline, Carol, Wilson, por todas as sugestões, conselhos e por estarem sempre prontos a ajudar.

Aos colegas Naína, Mônica, Luana, Sara, Éwerton, Rúbens, Lennon, Robert, Roberto, Débora, Priscila, Amanda e André, pela dedicação e por disponibilizar vários momentos de descontração.

Aos técnicos Eduardo Gimenes, Carolina Bertelli e Loren da Silva, por sempre auxiliarem no que for preciso e da melhor forma possível. Obrigada pessoal!

Ao apoio financeiro da Fundação de Amparo a Pesquisa do estado de São Paulo (FAPESP).

Ao pessoal do biotério do Departamento de Parasitologia, Sandra, Juliane, Daniele, Luís e Anderson, pelo zelo e dedicação com os animais.

Aos meus pais, Derci e Carlito, por todo o incentivo, carinho, confiança, compreensão e alegrias. Amo muito vocês!

À minha irmã, Denise sempre determinada, companheira, minha grande amiga e sempre cuidando de mim. Obrigada Mana!

Ao meu amor, Vitor, sempre presente, dedicado, carinhoso, compreensivo em todos os momentos, sempre me proporcionando momentos felizes, pelos seus conselhos e por ser meu grande amigo. Muito obrigada por me deixar fazer parte da sua vida e muito obrigada por me fazer muito feliz!

À minha segunda família, meus sogros Elza e Alfredo, minha cunhada Quel e Marcel, por me receberem, me acolherem nesta cidade imensa, por todo o carinho, confiança e respeito. Muito Obrigada! 
Deus, por me ajudar a realizar meus sonhos, sempre abençoando o meu caminho e ajudando a conquistar meus objetivos! 
Este trabalho foi realizado sob orientação do Prof. Dr. Luís Carlos de Souza Ferreira, no Centro de Vacinas e Terapia Gênica (CEVAT - GENE 4), no Departamento de Parasitologia do Instituto de Ciências Biomédicas da Universidade de São Paulo, com o apoio financeiro da Fundação de Amparo à Pesquisa do Estado de São Paulo (FAPESP). 
"Determinação, coragem e autoconfiança são fatores decisivos para o sucesso. Não importam quais sejam os obstáculos e as dificuldades. Se estivermos possuídos de uma inabalável determinação, conseguiremos superá-los. Independente das circunstâncias devemos ser sempre humildes, recatados e despidos de orgulho." 


\section{RESUMO}

FABRIS, D. N. L. Efeitos adjuvantes de derivados da toxina termo-lábil de Escherichia coli (LT1) na resposta de anticorpos específicos voltados para o domínio III da glicoproteína e do vírus dengue tipo 2 (DENV2). 2014. 88 f. Dissertação (Mestrado em Biologia da Relação Patógeno-Hospedeiro) - Instituto de Ciências Biomédicas, Universidade de São Paulo, São Paulo, 2014.

As toxinas termo-lábeis (LT), produzidas por linhagens de Escherichia coli enterotoxigênica (ETEC), possuem a habilidade de aumentar a resposta de anticorpos contra antígenos coadministrados e modular a produção de subclasses de IgG em camundongos vacinados pela via de mucosa ou parenteral. Embora existam diversos estudos sobre as atividades imunológicas das LTs, pouco é conhecido sobre a capacidade desses adjuvantes em induzir diferentes padrões de glicosilação em anticorpos IgG. Desta forma, o objetivo do presente trabalho foi caracterizar o papel de derivados de LT (LT1, LT1-K63 e LT1-B) na modulação da resposta imune mediada por anticorpos com ênfase na determinação do padrão de glicosilação de anticorpos IgG séricos após imunização de camundongos por via parenteral com uma forma recombinante do domínio III da glicoproteína $\mathrm{E}$ do envelope do vírus do Dengue tipo 2 (DENV2). Avaliamos também a influência desses adjuvantes na afinidade e na capacidade de neutralização viral in vitro do DENV2. A LT1 induziu maior resposta de IgG sérico EIII-específico em camundongos imunizados pela via subcutânea. Por outro lado, em relação à qualidade da resposta, os anticorpos gerados em camundongos imunizados com LT1-K63 e LT1-B apresentaram maior capacidade de neutralização viral em comparação com aqueles obtidos dos demais grupos vacinais. Observamos diferentes padrões de glicosilação, principalmente com relação à presença ou ausência de resíduos de ácido siálico, galactose e fucose na estrutura dos anticorpos purificados provenientes da administração das LTs como adjuvantes. A deglicosilação dos anticorpos IgG antígeno-específicos obtidos da imunização com LT1 ou LT1-K63 resultou na maior interação desses anticorpos com a proteína EIII, enquanto que anticorpos deglicosilados obtidos de animais tratados com LT1-B como adjuvante mostraram menor reconhecimento ao antígeno em comparação com os anticorpos glicosilados do mesmo grupo. Nossos resultados indicam a importância dos adjuvantes no perfil de glicosilação de anticorpos específicos e apontam para a influência da glicosilação na funcionalidade desses anticorpos. Esses resultados podem ter relevância para o desenvolvimento de vacinas contra a dengue.

Palavras-chave: Adjuvantes. Glicosilação. Toxina termo-lábil. Resposta humoral. 


\begin{abstract}
FABRIS, D. N. L. Adjuvant effects of Escherichia coli thermo-labile toxin (LT1) derivatives in the specific antibody response directed to the E glycoprotein domain III of type 2 dengue virus (DENV2). 2014. 88 p. Masters thesis (Biology of Host-Pathogen) Instituto de Ciências Biomédicas, Universidade de São Paulo, São Paulo, 2014.

The heat-labile toxins (LT) produced by enterotoxigenic Escherichia coli (ETEC) strains have been intensively investigated as potential vaccine adjuvants. LT toxins show ability to augment antibody responses against co-administered antigens and modulate IgG subclass production in mice vaccinated by mucosal or parenteral routes. Despite several studies dealing with the immunological activities of LT derivatives, little is known about the ability of these adjuvants induce different glycosylation patterns of IgG antibodies. Thus, the objective of the present study was to characterize the role of LT derivatives (LT1, LT1-K63 and LT1-B) in modulating the immune responses mediated by antibodies in mice with emphasis on the glycosylation pattern of serum IgG antibodies after parenteral immunization with a recombinant domain III from the envelope glycoprotein of dengue type 2 (DENV2). We also evaluated the influence of these adjuvants in affinity and of virus neutralization effects with a DENV2 strain. LT1 induced higher EIII-specific serum IgG responses in mice immunized subcutaneously. On the other hand, the antibodies elicited in mice immunized with LT1-K63 or LT1-B showed better virus neutralization effect than those derived from the other immunization groups. We observed different antibody glycosylation patterns, particularly with respect to the presence or absence of sialic acid, galactose and fucose, after administration of different LTs as adjuvants. The deglycosylation of antigen-specific IgG antibodies obtained from immunization with LT1 or LT1-K63 resulted in a greater interaction with the EIII protein, while deglycosylated antibodies harvested from LT1-B-treated animals showed lower antigen recognition than glycosylated antibodies obtained from the same group. Our results emphasize the relevance of the adjuvants in the antibody glycosylation patterns and a possible impact in the function of these antibodies. These findings may be relevant for the development of vaccines against dengue.
\end{abstract}

Keywords: Adjuvant. Heat-labile Toxin. Glycosylation. Humoral response. 


\section{LISTA DE FIGURAS}

Figura 1. Representação esquemática da estrutura da toxina termo-lábil de Escherichia coli

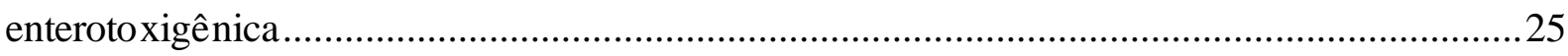

Figura 2. Representação esquemática da estrutura dos anticorpos........................................30

Figura 3. Representação esquemática dos sítios de glicosilação na estrutura de anticorpos $\operatorname{IgM}, \operatorname{IgD}, \operatorname{IgG} 1, \operatorname{IgA} 1, \operatorname{IgA} 2 \mathrm{~m}$ e IgE.. 31

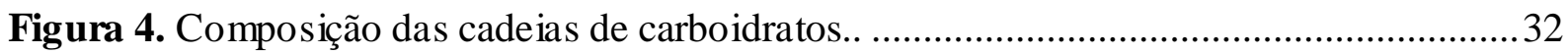

Figura 5. Clonagem do gene eltB em vetor pET22b e análise de expressão em células Escherichia coli BL21 DE3 pLys .....

Figura 6. Purificação e caracterização da proteína LT1, LT1-K63 e LT1-B. .........................51

Figura 7. Purificação e caracterização da proteína EIII.........................................................52

Figura 8. Representação esquemática dos ensaios de imunização e análise da resposta humoral EIII-específica induzida pelos adjuvantes

Figura 9. Análise da resposta humoral EIII-específica induzida pelos adjuvantes com proteínas não tratadas e tratadas para a remoção de LPS

Figura 10. Análise da resposta humoral EIII-específica em animais C57BL/6 selvagens e nocautes para o receptor TLR4 após imunização com o adjuvante LT1

Figura 11. Purificação de anticorpos IgG EIII-específicos gerados após a imunização com EIII sozinha ou coadministrada com os adjuvantes.

Figura 12. Caracterização dos anticorpos IgG anti-EIII deglicosilados após tratamento com enzima PNGase F

Figura 13. Determinação da afinidade dos anticorpos IgG EIII-específicos glicosilados e deglicosilados em aparelho BIAcore

Figura 14. Análise dos diferentes perfis de glicosilação em anticorpos IgG EIII-específicos obtidos dos animais imunizados com proteínas não tratadas para redução do LPS por ELISA com uso de lectinas

Figura 15. Análise dos diferentes perfis de glicosilação em anticorpos IgG EIII-específicos obtidos dos animais imunizados com proteínas tratadas para redução do LPS por ELIS A com uso de lectinas

Figura 16. Análise dos diferentes perfis de glicosilação em anticorpos IgG de animais imunizados com PBS e IgG EIII-específicos dos animais imunizados com EIII sozinha por espectrometria de massa em aparelho MALDI-TOF/TOF 
Figura 17. Análise dos diferentes perfis de glicosilação em anticorpos IgG EIII-específicos dos animais imunizados com EIII coadministrada com o adjuvante LT1 ou LT1-K63 por espectrometria de massa em aparelho MALDI-TOF/TOF

Figura 18. Análise dos diferentes perfis de glicosilação em anticorpos IgG EIII-específicos dos animais imunizados com EIII coadministrada com o adjuvante LT1-B ou Alúmen por espectrometria de massa em aparelho MALDI-TOF/TOF 


\section{LISTA DE TABELAS}

Tabela 1. Adjuvantes vacinais aprovados para uso em seres humanos. ...............................25

Tabela 2. Padrões de carboidratos encontrados na porção Fc dos anticorpos IgG. .................33

Tabela 3. Efeito dos adjuvantes na afinidade e neutralização dos anticorpos anti-EIII. .........59

Tabela 4. Resumo das glicoformas encontradas atra vés da análise por MALDI-TOF/TOF...69 


\section{LISTA DE ABREVIATURAS E SIGLAS}

A

ADCC

ADP

AMPc

ANOVA

APC

$\mathrm{ASN}^{297}$

CD

$\mathrm{CD}^{+}$

$\mathrm{CD}^{+}$

CD80

CD86

CEFAP

CEUA

CMC

Con A

$\mathrm{CNBr} 4 \mathrm{~B}$

CPG

CT

CXCL13

$\mathrm{C} 1$

C-18

$\mathrm{DC}$

DENV

$\mathrm{DHB}$
Ácido siálico

Antibody Dependent Cell mediated Cytotoxicity (Citotoxidade celular media por anticorpo)

Adenosine diphosphate (adenosina difosfato)

Cyclic adenosine monophosphate (monofosfato cíclico de adenosina)

Analysis of variance (Análise de Variância simples)

Antigen presenting cells (células apresentadoras de antígeno)

Asparagine (asparagina sítio 297)

Cluster of differentiation (grupo de diferenciação)

Cluster of differentiation $4^{+}$(grupo de diferenciação)

Cluster of differentiation $8^{+}$(grupo de diferenciação)

Cluster of differentiation 80 (grupo de diferenciação)

Cluster of differentiation 86 (grupo de diferenciação)

Centro de Facilidades de Apoio á Pesquisa

Comissão de Ética no uso de animais

Carboximetilcelulose

Concanavalin A (Concanavalina A)

Cyanogen bromide activated $4 B$ resin (resina ativada com brometo de cianogenio )

Oligodeoxynucleotides Syntetic contain cytosine and guanine (Oligodeoxinucleotídeo sintético contendo Citosina e Guanina)

Cholera toxin (toxina colérica)

C-X-C motif chemokine 13 (quimiocina 13 com domínio C-X-C)

Componente 1 do sistema complemento

Solid phase extraction cartridges

Dendritic cells (células dendríticas)

Dengue vírus (vírus da dengue)

Matrix 2,5-ácido Dihidroxibenzóico 
DHF

DMSO

DNA

DSS

DTT

ELISA

EPAC

ETEC

EIII

F

Fab

Fc

GD1a

GD1b

GM1

GM2

GTP

Gs $\alpha$

IL

INF $\gamma$

Ig

$\operatorname{IgA}$

IgA1
Dengue haemorrhagic fever (febre da dengue hemorrágica)

Dimetil sulfóxido

Deoxyribonucleic acid (ácido desoxirribonucleico)

Dengue shock syndrome (síndrome do choque da dengue)

Diotreitol

Enzyme Linked Immunosorbent Assay (ensaio imunoabsorvente ligado à enzima)

Exchange protein directly activated by cAMP (proteína trocadora diretamente ativada pelo AMPc)

Enterotoxigenic Escherichia coli (Escherichia coli enterotoxigênica)

Domínio III da glicoproteína E do envelope do vírus da dengue

Fucose

Fragment antigen binding (região de ligação com os antígenos)

Fragment crystallizable (região cristalizável constante)

Disialoganglioside 1a (disialogangliosídeo 1a)

Disialoganglioside 1b (disialogangliosídeo 1b)

Monosialotetrahexosylganglioside 1 (monosialotetrahexosilgangliosídeo 1)

Monosialotetrahexosylganglioside 2 (monosialotetrahexosilgangliosídeo 2)

Guanosine triphosphate (guanosina trifosfato)

$\alpha$-subunit of the stimulatory $G$ protein (subunidade alfa da proteína $G$ estimulatória)

Interleucina

Interferon gamma (interferon gama)

Imunoglobulina

Imunoglobulina A

Subclasse tipo 1 de imunoglobulina A 
$\operatorname{IgA} 2$

$\operatorname{IgA} 2(\mathrm{~m})$

$\operatorname{IgE}$

IgG

IgG1

IgG2

IgG2a

$\mathrm{IgG} 2 \mathrm{c}$

IgG3

IgG4

$\operatorname{IgM}$

IPTG

LPS

LT

LAL

M

MHC II

$\mathrm{N}$

$\mathrm{NAD}^{+}$

Nalp3

NK

Nlrp3

NOD
Subclasse tipo 2 de imunoglobulina A

Alótipos de classe tipo 2 de imunoglobulina A

Imunoglobulina $\mathrm{E}$

Imunoglobulina $\mathrm{G}$

Subclasse tipo 1 de imunoglobulina $G$

Subclasse tipo 2 de imunoglobulina $G$

Subclasse tipo 2a de imunoglobulina G

Subclasse tipo 2c de imunoglobulina G

Subclasse tipo 3 de imunoglobulina $\mathrm{G}$

Subclasse tipo 4 de imunoglobulina $\mathrm{G}$

Imunoglobulina $\mathrm{M}$

Isopropyl $\beta$-D-1 thiogalactopyranoside (isopropil $\beta$-D-1

tiogalactopiranosideo)

Lipolis sacarídeo

Heat-labile toxin (toxina termo-lábel)

Limulus amebócyte Lysate (lisado de Limulus amebócito)

Manose

Matrix Assisted Laser Desorption Ionization time of flight mass

MALDI-TOF/TOF spectrometer (ionização/dessorção de matriz assistida por laser e espectrômetro de massa por tempo de voo)

Major histocompatibility complex class II (complexo maior de histocompatibilidade tipo II)

$N$-acetilglicosamina

Nicotinamide adenine dinucleotide (dinucleotído de nicotinamida e adenina)

PYD domains-containing protein 3 (proteína contendo 3 domínio pirina)

Cells natural killers (células matadoras profissionais)

NOD-like receptor family pyrin domain containing 3 (proteína receptora do tipo NOD contendo 3 domínios pirina

Domain oligomerization nucleotides (domínio de oligomerização de 
nucleotídeo)

NS1

Non structural protein 1 (proteína não-estrutural 1)

PBS

Phosphate buffered saline (tampão fosfato-salino)

PCR

Polymerase Chain Reaction (reação de cadeia e polimerase)

PKA

Protein kinase A (proteína quinase A)

PNGase F

Peptide N Glycosidase F

RNA

Ribonucleic acid (acido ribonucleico)

SFB

Soro fetal bovino

SPR

Surface plasmon resonance (ressonância plasmônica de superfície)

TFA

Acid trifluoro acetic (ácido trifluoroacético)

TGF $\beta$

Transforming growth factors $\beta$ (fator de crescimento transformante $\beta$ )

Th1

Cells Thelper (células $\mathrm{T}$ auxiliadoras 1)

Th2

Cells Thelper (células T auxiliadoras 2)

Th17

Cells Thelper (células T auxiliadoras 17)

TLR4

Toll-like receptor 4 (receptor do tipo toll 4 )

UFP

Unidade formadora de placa 


\section{LISTA DE SÍMBOLOS}

\begin{tabular}{|c|c|}
\hline${ }^{\circ} \mathrm{C}$ & Grau Celsius \\
\hline $\mathrm{cm}$ & Centímetro \\
\hline D. $\mathrm{O}_{600 \mathrm{~nm}}$ & Densidade ótica a 600 nanômetros \\
\hline EU & Unidade endotóxica \\
\hline $\mathrm{g}$ & Força centrifuga relativa $(\mathrm{RCF})$ ou força gravitacional \\
\hline $\mathrm{KDa}$ & Kilodalton \\
\hline $\mathrm{L}$ & Litro \\
\hline $\mathrm{M}$ & Molar \\
\hline $\mathrm{m} / \mathrm{z}$ & Massa/carga \\
\hline $\mathrm{mM}$ & Milimolar \\
\hline $\mathrm{mg}$ & Miligrama \\
\hline $\mathrm{mg} / \mathrm{mL}$ & Miligrama/mililitro \\
\hline $\min$ & Minuto \\
\hline $\mathrm{mL}$ & Mililitro \\
\hline $\mathrm{nM}$ & Nanomolar \\
\hline $\mathrm{pH}$ & Potencial de hidrogênio \\
\hline $\mathrm{pb}$ & Pares de bases \\
\hline psi & Pound force per square inch (libra força por polegada quadrada) \\
\hline rpm & Rotação por minuto \\
\hline$\mu \mathrm{L}$ & Microlitro \\
\hline$\mu \mathrm{g} / \mu \mathrm{L}$ & Micrograma/microlitro \\
\hline$\mu \mathrm{m}$ & Micrometro \\
\hline$\%$ & Porcentagem \\
\hline$\Delta \mathrm{RU}$ & Unidade de ressonância \\
\hline
\end{tabular}




\section{SUMÁRIO}

1 INTRODUÇÃ

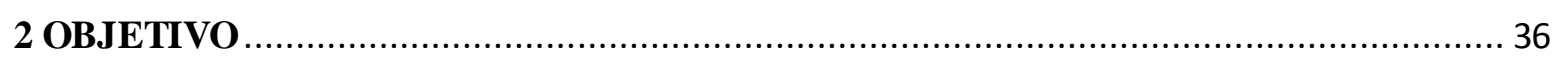

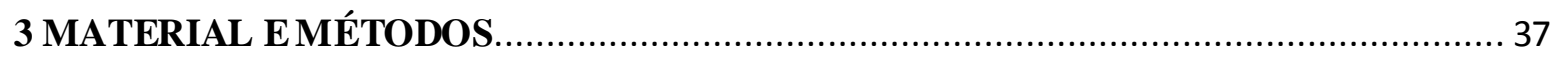

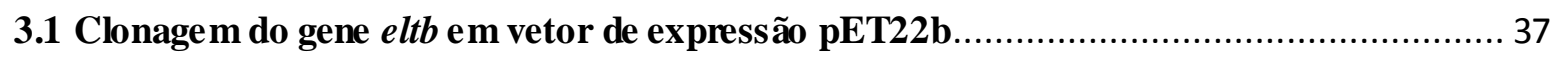

3.2 Expressão e purificação da proteína LT1-B recombinante .......................................... 38

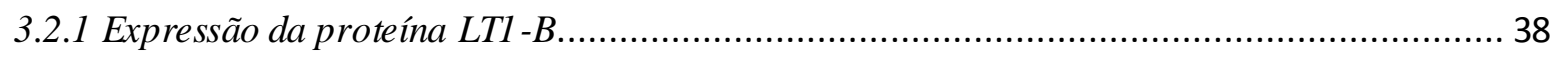

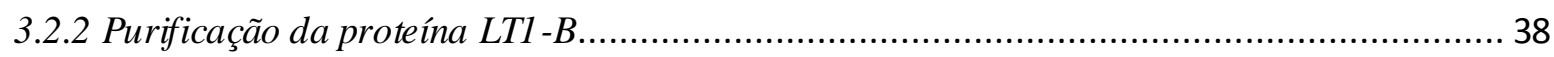

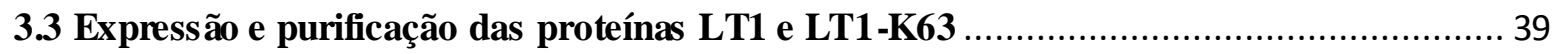

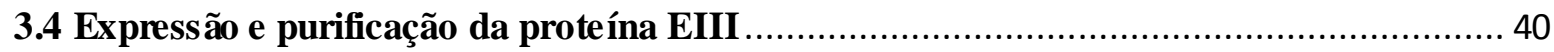

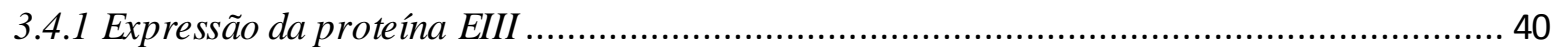

3.4.2 Renaturação da proteína EIII por diluição pulsada .................................................... 40

3.4 .3 Purificação da proteína EIII ................................................................................ 41

3.5 Remoção e quantificação de lipolissacarídeo (LPS) presente nas proteínas utilizadas na

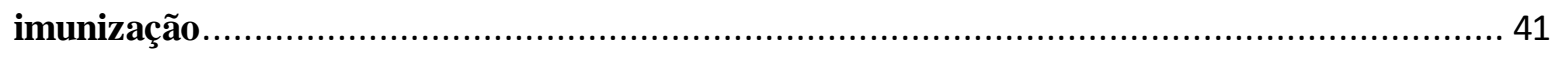

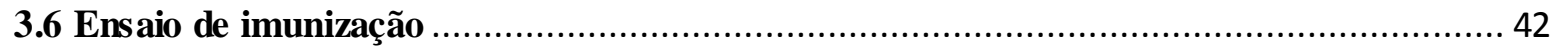

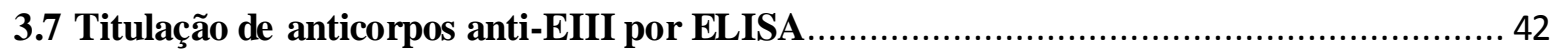

3.8 Ensaio de afinidade com os anticorpos EIII-específicos........................................... 43

3.9 Dete rminação da capacidade de ne utralização viral dos anticorpos EIII-específico ......... 43

3.10 Purificação dos anticorpos IgG EIII-es pecíficos ................................................. 44

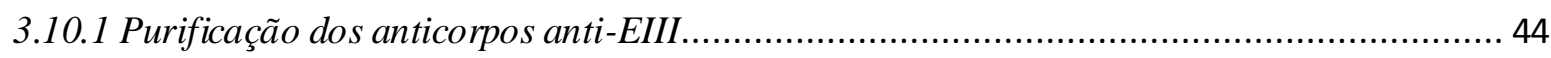

3.10.2 Purificação dos anticorpos Ig G EIII-específicos........................................................ 44

3.11 Caracte rização do padrão de glicosilação dos anticorpos IgG EIII-específicos por ELISA

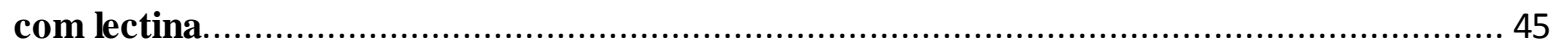

3.12 Análise de $N$-glicanos presentes na estrutura dos anticorpos IgG EIII-específicos.......... 45

3.12.1 Deglicosilação em condições desnaturantes .............................................................. 45

3.12.2 Dessalinização dos $N$-glicanos liberados por ação da enzima PNGase F ........................ 46

3.12.3 Permetilação dos $\mathrm{N}$-glicanos purificados .................................................................... 46

3.12.4 Análise das cadeias de carboidratos por espectrometria de massa MALDI-TOF/TOF........ 46

3.13 Deglicosilaçãodos oligoss acarídeos N-ligados da estrutura dos anticorpos IgG anti-EIII

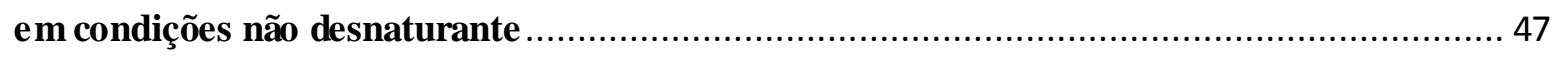

3.14 Ensaio de ligação de anticorpos IgG anti-EIII em microchip via s is tema BIAcore ........ 47

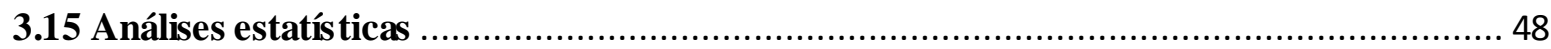


4.1 Clonagem do gene eltB em vetor de expressão pET22b e expressão da proteína

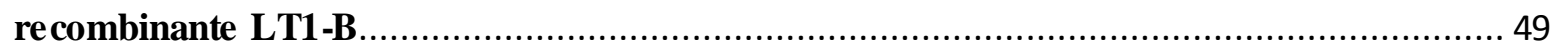

4.2 Purificações das proteínas LT1, LT1-K63, LT1-B e EIII................................................ 50

4.3 Ensaios de imunização e titulação de anticorpos anti-EIII por ELISA ........................... 52

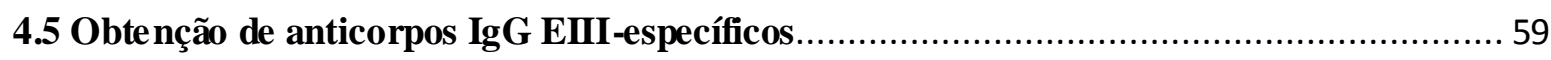

4.6 Deglicosilação dos anticorpos IgG EIII-específicos comendoglicosidase PNGase F.......... 61

4.7 Determinação da ligação dos anticorpos IgG anti-EIII via siste ma BIAcore ...................63

4.9 Análise do padrão de glicosilação dos anticorpos IgG EIII-específicos por espectrometria

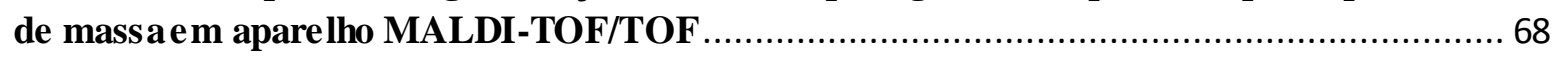

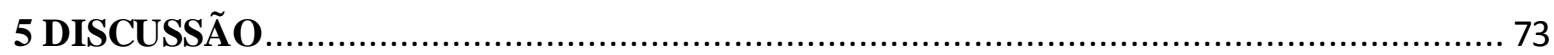

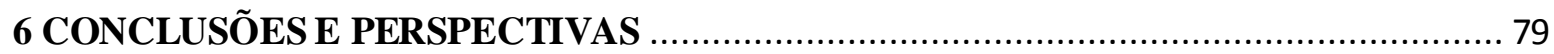

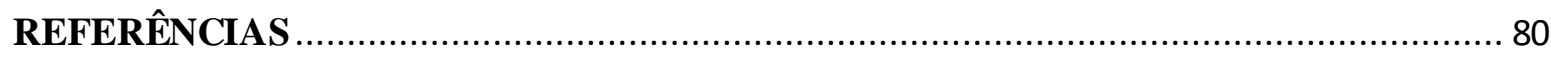

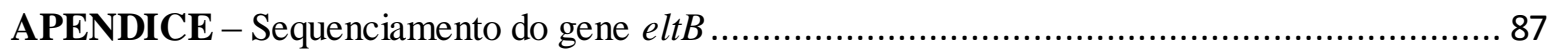




\section{INTRODUÇÃO}

Estudos relacionados à imunização ativa iniciaram-se com pesquisas de Edward Jenner e Louis Pasteur que desenvolveram vacinas contra varíola e raiva, respectivamente, com base na utilização de formas patogênicas com menor potencial infeccioso (atenuação natural ou artificial). A maioria das vacinas utilizadas atualmente baseia-se nos conceitos desenvolvidos por esses pesquisadores e no princípio da inativação do agente etiológico da doença, alterando-se apenas a metodologia empregada para a atenuação ou inativação do patógeno (PLOTKIN, 2005). Com o advento da biologia molecular, foi possível desenvolver novos conceitos vacinais como, por exemplo, as vacinas de subunidades, que envolvem a utilização de proteínas recombinantes e purificadas ou peptídeos sintéticos e, portanto, apresentam menor reatogenicidade e maior segurança clínica para o uso em seres humanos e outros animais. No entanto, essa proposta vacinal não é capaz de estimular o sistema imunológico adequadamente quando o antígeno alvo administrado apresenta baixa imunogenicidade, sendo essencial a incorporação de compostos adjuvantes na formulação vacinal (HORA et al., 2011; PASHINE et al., 2005).

Adjuvantes são substâncias capazes de estimular o sistema imunológico e de amplificar, modular ou prolongar a imunogenicidade intrínseca de antígenos alvos (coadministrados, conjugados quimicamente ou fusionados geneticamente), melhorando a eficácia das vacinas (HORA et al., 2011; MOTA; LIMA; MELO, 2006; RESENDE et al, 2004). Os adjuvantes podem auxiliar a indução de resposta de defesa do hospedeiro por diferentes formas: (i) induzindo resposta inflamatória no local da inoculação pela ativação de células do sistema imunológico inato; (ii) aumentando o contato das células imunológicas com o antígeno, como por exemplo através do depósito do antígeno no local da inoculação e de sua liberação gradual; (iii) tornando a resposta imunológica mais rápida e duradoura pela indução de células imunológicas de memória; (iv) modulando a qualidade e especificidade dessa resposta pela ativação do sistema imunológico adquirido e pelo direcionamento da resposta para Th1, Th2 e/ou Th17; e (vi) induzindo imunidade de mucosa (REZENDE et al., 2004). Apesar dessa compreensão geral sobre as atividades dos adjuvantes, existe na literatura carência de informações sobre os exatos mecanismos pelos quais esses compostos agem sobre o sistema imunológico. Poucos adjuvantes estão aprovados para uso em formulações vacinais dirigidas à seres humanos (Tabela 1). Várias formulações adjuvantes vêem sendo testadas em ensaios clínicos, e são considerados bons candidatos para o desenvolvimento de novas formulações vacinais utilizadas em grupos de indivíduos específicos, considerando a idade 
(fetos, recém-nascidos, crianças, adolescentes, adultos e idosos) e condição (viajantes, pacientes com doenças crônicas, imunossuprimidos, indivíduos em condições de pobreza) (RAPPUOLI et al., 2011; REED et al., 2013).

Em relação a seu mecanismo geral de ação os adjuvantes podem ser divididos em imunopotencializadores e em sistemas de entrega. Os imunopotencializadores atuam diretamente sobre as células imunológicas e dentre eles podemos citar os produtos bacterianos como toxinas e peptideoglicanos, citocinas e ácidos nucléicos. Enquanto os sistemas de entrega direcionam os antígenos para reconhecimento e processamento pelas células do sistema imunológico e dentro dessa categoria podemos citar os lipossomas, os sais de alumínio, os agentes sulfactantes, as emulsões e as micropartículas sintéticas. Vale ressaltar que determinados compostos possuem ambas as características, funcionando tanto como um imunopotencializador quanto como um sistema de entrega, como por exemplo, os sais de alumínio (HORA et al., 2011; PASHINE et al., 2005). O sulfato de alumínio e potássio (Alúmen) libera gradualmente o antígeno pela formação de depósito nos tecidos, prolongando sua exposição e entrega às células do sistema imunológico. Observações mais recentes apontam que a formação de complexo entre o Alúmen e o antígeno aumenta sua absorção pelas células apresentadoras de antígeno (APC - antigen presenting cells) e permite a ativação de moléculas do complexo do inflamassoma: proteína receptora do tipo domínio de oligomerização de nucleotídeo (NOD - domain oligomerization nucleotides) com três domínios pirina (Nlrp3 - NOD like receptor Family pyrin domain containing 3) ou proteína contendo 3 domínio pirina (Nalp3 - PYD domains containing protein 3). Além disso, o Alúmen também atua sobre eosinófilos e monócitos (MCKEE et al, 2009; MOTA; LIMA; MELO, 2006; PLOTKIN, 2005; REZENDE et al., 2004). Outro exemplo de molécula com duplicidade de atuação adjuvante são as toxinas bacterianas. As toxinas, embora sejam reconhecidas como potentes imunoestimuladores, podem também funcionar como sistemas de entrega quando antígenos são fusionados a estas moléculas, posto que se ligam às células eucarióticas através da interação com receptores de superfície.

Em estudos relacionados ao uso de toxinas como adjuvantes, destaca-se o interesse de alguns pesquisadores pela toxina termo-lábil (LT - heat labile toxin) da Escherichia coli enterotoxigênica (ETEC - enterotoxigenic Escherichia coli) e pela toxina colérica (CT cholera toxin) de Vibrio cholerae. As toxinas LT e CT apresentam uma subunidade A de 27 $\mathrm{kDa}$ responsável pela atividade enzimática de adenosina difosfato ribosilação (ADP adenosine diphosphate ribosylation) e uma subunidade B composta por cinco polipeptídios idênticos $(11,5 \mathrm{kDa})$ estruturados em forma de um anel pentamêrico e responsável pela 
ligação a receptores presentes na superfície das células hospedeiras (Figura 1). Ambas as toxinas interagem com alta afinidade ao monosialotetrahexosilgangliosídeo (GM1 monosialotetrahexosylganglioside), mas apenas LT apresenta capacidade de se ligar fracamente a outros glicoesfingolipídeos disialogangliosídeo ((GD1a - disialoganglioside), GD1b, GM2, dentre outros) e a receptores glicoproteicos (COX et al., 2006; FAN et al., 2000; LENCER et al., 1999). LT e CT possuem atividade citotóxica que se processa quando elas são produzidas e liberadas no lúmen intestinal.

Tabela 1. Adjuvantes vacinais aprovados para uso em seres humanos.

\begin{tabular}{|c|c|c|c|}
\hline Adjuvante & Classe do adjuvante & Composição & Vacina/doença \\
\hline $\begin{array}{l}\text { Alúmen } \\
(1929)^{*}\end{array}$ & Sal mineral & $\begin{array}{l}\text { Hidróxido de alumínio } \\
\text { ou fosfato de alumínio }\end{array}$ & $\begin{array}{l}\text { Hepatite A, Hepatite B, Difteria, Tétano, } \\
\text { Haemophilus influenzae do tipo b }\end{array}$ \\
\hline $\begin{array}{c}\text { MF59 } \\
(1997, \text { Novartis)* }\end{array}$ & $\begin{array}{l}\text { Emulsão óleo em } \\
\text { água }\end{array}$ & $\begin{array}{l}\text { Escaleno, polissorbato } \\
80 \text { (T ween } 80 \text { ), trioleato } \\
\text { de sorbitano }\end{array}$ & $\begin{array}{c}\text { Fluad® (influenza), } \\
\text { Focetria }{ }^{\circledR} \text { e Celtura } ₫(\text { influenza H1N1), } \\
\text { Aflunov® (influenza H5N1) }\end{array}$ \\
\hline $\begin{array}{c}\text { AS04 } \\
(2005, \text { GlaxoSmithKlyne) }\end{array}$ & $\begin{array}{l}\text { Agonista de TLR4 } \\
\text { adsorvido em } \\
\text { Alúmen }\end{array}$ & $\begin{array}{l}\text { Monofosforil Lipídio A } \\
\text { Hidróxido de alumínio }\end{array}$ & $\begin{array}{c}\text { Cervarix }{ }^{\mathrm{TM}} \text { (papiloma vírus humano HPV), } \\
\text { Fendrix }{ }^{\circledR} \text { (Hepatite B) }\end{array}$ \\
\hline $\begin{array}{c}\text { AS03 } \\
(2009, \text { GlaxoSmithKlyne })^{*}\end{array}$ & $\begin{array}{l}\text { Emulsão óleo em } \\
\text { água }\end{array}$ & $\begin{array}{l}\text { Escaleno, Tween } 80 \mathrm{e} \\
\alpha \text {-tocoferol }\end{array}$ & Pamdremix ${ }^{\circledR}$ e Prepandix $®($ Influenza) \\
\hline $\begin{array}{c}\text { Virossomos } \\
(2000, \text { Berna Biotech }) *\end{array}$ & Lipossomos & $\begin{array}{l}\text { Lipídeos, } \\
\text { hemaglutinina }\end{array}$ & $\begin{array}{c}\text { Inflexal®V e Invivac } ® \text { (Influenza), } \\
\text { Epaxal® (Hepatite A) }\end{array}$ \\
\hline
\end{tabular}

*Ano de licenciamento do adjuvante. Fonte: Modificado de Awate et al. (2013); Rappuoli et al. (2011).

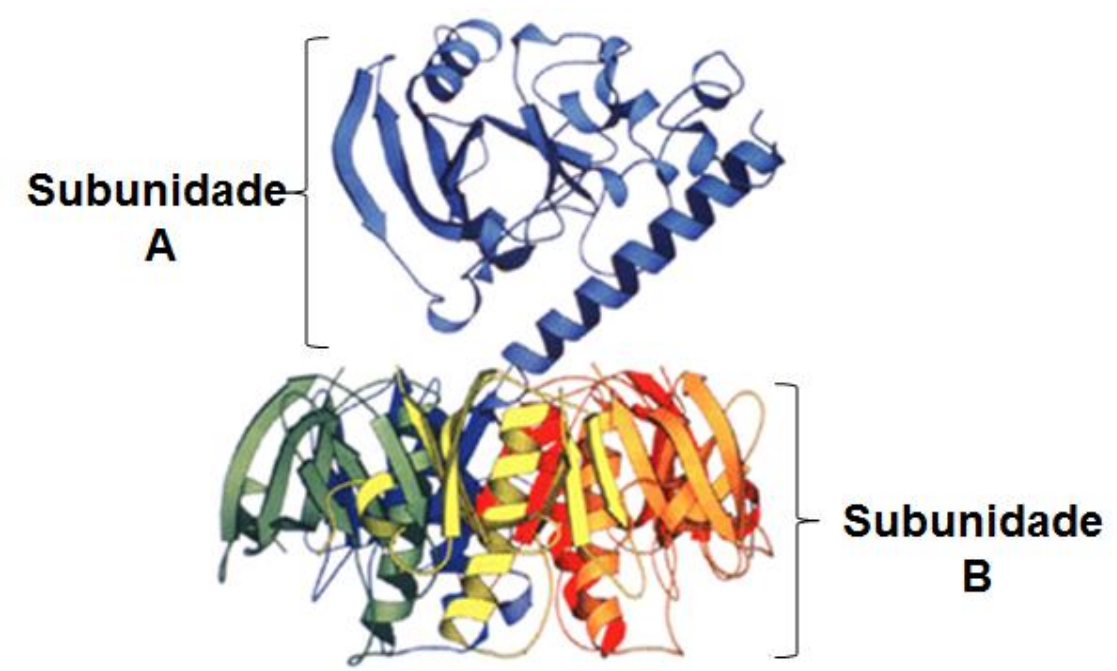

Figura 1. Representação esquemática da estrutura da toxina termo-lábil de Escherichia coli enterotoxigênica Observa-se a subunidade $\mathrm{A}$ formada pela porção A1 globular e enzimaticamente ativa ligada covalentemente à porção A2 em alfa hélice, a qual interage com a subunidade B composta por cinco anéis polipeptídicos estruturados em forma de ane] pentamêrico. Fonte: Modificado de Salmond et al. (2002). 
Inicialmente, as toxinas se ligam a receptores GM1, são endocitadas e translocadas por transporte vesicular do complexo de Golgi para o retículo endoplasmático. Durante este processo ocorre a clivagem proteolítica e a redução da ponte de dissulfeto por ação da enzima dissulfeto isomerase entre os domínios A1 e A2 das holotoxinas. O fragmento A1 enzimaticamente ativo e livre no citoplasma atua transferindo o radical ADP-ribosil do cofator dinucleotído de nicotinamida e adenina ( $\mathrm{NAD}^{+}$- nicotinamide adenine dinucleotide) para a subunidade alfa da proteína estimulatória ( $\mathrm{Gs} \alpha$ - $\alpha$-subunit of the stimulatory $G$ protein) ligante de guanosina trifosfato (GTP - guanosine triphosphate). Uma vez ativada, a proteína $\mathrm{G}$ associa-se ao complexo enzimático adenilatociclase, resultando em sua permanente estimulação e aumentando, consequentemente, os níveis de monofosfato cíclico de adenosina (AMPc - cyclic adenosine monophosphate) intracelular. Assim a proteína quinase A (PKA protein kinase A) dependente de AMPc é ativada pelo AMPc, direcionando fosforilação anormal dos canais de cloro e de sódio, o que culmina na liberação de íon de $\mathrm{Cl}^{-}$e na inibição de absorção de íons de $\mathrm{Na}^{+}$, bem como no transporte passivo de água para o lúmen intestinal. O acúmulo de íon e água no intestino caracteriza a diarreia aquosa desencadeada por LT e CT (KNUTTUN et al., 1987; NATARO; KAPER, 1998).

A ação fisiológica das LTs tem sido até o momento a base para a compreensão de sua atividade adjuvante, posto que essas toxinas induzem produção de prostaglandinas e leucotrienos, que estão envolvidos em processos pró-inflamatórios, e produção de AMPc, que é um regulador universal de função celular (NATARO; KAPER, 1998; PETERS-GOLDEN, 2009). O AMPc atua como modulador central de várias funções das células imunológicas, tais como migração, adesão, proliferação e diferenciação celular, apoptose e produção de quimiocinas e citocinas (GRANDOCH et al., 2010; KAMMER, 1988). Originalmente, AMPc foi descrito como ativador exclusivamente da proteína PKA, no entanto observações mais recentes demonstraram seu efeito regulador sobre outros sensores como proteína trocadora diretamente ativada pelo AMPc (Epac - Exchange protein directly activated by $c A M P$ ). De modo geral, PKA e Epac promovem proliferação e sobrevivência celular, aprendizagem e formação de memória imunológica. Além disso, os efeitos isolados ou combinados de PKA e Epac podem resultar em inibição ou estimulação das funções das células imunológicas e de processos inflamatórios, dependendo do estágio de diferenciação celular, do tipo de célula e dos estímulos adicionais (GRANDOCH et al., 2010; PETERS-GOLDEN, 2009). No caso da ação de LT sobre o sistema imunológico, os estímulos adicionais estão relacionados à porção não enzimática da proteína. A ligação da subunidade $\mathrm{B}$ a receptores gangliosídeo (glicoesfingolípídios) pode induzir alterações na composição dos agrupamentos de lipídios 
associados a proteínas em micro domínios da membrana externa (rafts de lipídeos), resultando em mudanças de transdução de sinais intracelulares que podem culminar em ativação celular, proliferação e diferenciação em vários tipos de células, incluindo células imunológicas (ARCE et al, 2005; HAAN; HIRST, 2004; MILJAN; BREMER, 2002). Outras regiões reguladoras presentes na LT são também associadas com o efeito adjuvante, posto que foi relatada a existência de mutantes de LT produzidos em laboratório com atividades enzimáticas e de ligação ao GM1 preservadas, mas com efeito adjuvante reduzido (FRASER et al., 2003; HAJISHENGALLIS et al., 2005; RYAN et al., 2000). O conjunto das propriedades imunomoduladoras dos domínios e subunidades de LT geram seu potencial adjuvante. Permanece ser esclarecido, no entanto, o modo pelo qual essas atividades de regulação imunológica se equilibram e se integram. Este conhecimento é essencial para a manipulação adequada e precisa desse produto bacteriano como adjuvante vacinal.

Assim, a LT possui um importante papel na patogenicidade de ETEC como também representa uma interessante molécula do ponto de vista biotecnológico, particularmente no desenvolvimento de vacinas. LT induz potente resposta imunológica humoral e celular quando administrada por vias de imunização parenteral, transcutânea e de mucosa. Apesar do mecanismo adjuvante dessa toxina não estar completamente esclarecido, sabe-se que promove a ativação de células $B$ e induz forte resposta de IgG sérico e IgA secretado ( $\mathrm{S}$-IgA) na mucosa, associados com a presença de células $\mathrm{T}$ auxiliares grupo de diferenciação (CD cluster of differentiation) $4^{+}$(resposta mista de linfócitos T auxiliares (Th - Thelper) 1/Th2) e $\mathrm{CD}^{+}$antígeno-específico e produção de interferon gama (IFN- $\gamma$ - interferon gamma), interleucina 4 (IL-4), IL-5, IL-6 e/ou IL10. Além dis so, essas toxinas promovem a maturação de células dendríticas (DCs - dendritic cells) aumentando a sua capacidade de apresentação de antígeno via expressão de moléculas do complexo principal de his tocompatibilidade (MHC major histocompatibility complex) classe II e moléculas co-estimulatórias CD80 e CD86 (BRAGA et al., 2014; FREYTAG; CLEMENTS, 2005; FUJIHASHI et al., 2002; GIULIANI et al., 1998; HAAN, 1999). Em estudos realizados por Brereton e colaboradores (2011), verificaram que a toxina LT é capaz de induzir a produção de citocina IL-17 por DCs ativadas em ensaios in vitro e in vivo quando coadministrado com o antígeno, através da indução da produção de IL-1 $\beta$ via ativação dos componentes do inflamassoma caspase 1 e Nlrp3 em DCs que promovem o desenvolvimento de células Th17.

A principal limitação no uso dessas enterotoxinas como adjuvantes em formulações vacinais dirigidas para humanos é obviamente o efeito tóxico desencadeado até mesmo quando pequenas doses são administradas por via de mucosa ou parenteral (FREYTAG; 
CLEMENTS, 2005). Por isso, vários grupos de pesquisa investiram em estudos que gerassem mutantes de LT atóxicos ou atenuados. A LTK63 é um exemplo de um desses mutantes atóxicos e apresenta a substituição de uma serina por uma lisina na posição 63 da subunidade $\mathrm{A}$, região onde o $\mathrm{NAD}^{+}$interage com a toxina para que o ADP-ribosil possa ser transferido para a proteína Gsa (DI TOMMASO et al., 1996). O uso de LTK63 como adjuvante pelas vias de mucosa ou parenteral induz aumento da migração de células dendríticas e macrófagos para o centro germinativo do baço, estas células secretam a quimiocina 13 com domínio C-XC (CXCL13 - C-X-C motif chemokine 13) que atraem células B imaturas para o baço, resultando na ativação de células $\mathrm{B}$ e, consequentemente, promovendo rápida mudança de classes de imunoglobulinas e aumento na produção de anticorpos antígeno-específicos (BJARNARSON et al., 2012; OLAFSDOTTIR et al., 2007). Adicionalmente, LTK63 ativa linfócitos T CD4 ${ }^{+}$, induzindo aumento na expressão de citocinas INF- $\gamma$, IL-4, IL-5, IL-10, IL12 (BJARNARSON et al., 2012; HORA et al., 2011; OLAFSDOTTIR et al., 2007; RYAN et al., 2000; TRITTO et al., 2007). A dose do adjuvante LTK63 pode influenciar no perfil de resposta imunológica gerada: doses altas podem gerar um padrão de resposta balanceado Th1/Th2, enquanto doses baixas induzem preferencialmente resposta Th1 (FREYTAG; CLEMENTS, 2005; RYAN et al., 2000). As diferenças de modulação de resposta imunológica de LTK63 é também observadas quanto ao padrão de subclasses de IgG induzido in vivo. A administração de LTK63 como adjuvante por vias de imunização parenteral e de mucosa também estimula a produção anticorpos $\operatorname{IgG}$ séricos e $\mathrm{S}$-IgA antígeno-específico (GIULIANI et al., 1998; RAPPUOLI et al, 1999; RYAN et al., 2000).

Outro derivado atóxico de LT que representa um promissor adjuvante, particularmente por via de administração parenteral, é a subunidade B de LT (LTB). Dentre os efeitos imunológicos gerados por LTB, podemos citar: (i) ativação de macrófagos e células dendríticas para processamento de antígeno e apresentação por MHC-II dos epítopos; (ii) indução de secreção das citocinas INF- $\gamma$, IL-2, IL-4 e IL-10, favorecendo a modulação para resposta Th1 e/ou Th2 dependendo da via de imunização e do antígeno; (iii) estimulação de proliferação e ativação de células B, promovendo produção de anticorpos séricos e de mucosa e (iv) modulação das respostas mediadas por linfócitos $\mathrm{T} \mathrm{CD8}{ }^{+}$, induzindo apoptose dessas células in vitro e ativando-as após inoculação parenteral do antígeno fusionado a molécula de LTB (FRASER et al, 2003; HAAN et al., 1998; HORA et al., 2011; NASHAR et al., 1997; TRUITT et al., 1998). As propriedades adjuvantes de LTB dependem da via de administração utilizada e da forma pelo qual o antígeno é associado (coadministração, fusão genética ou conjugação química) (HORA et al., 2011), porém com base nos trabalhos desenvolvidos até o 
momento não é possível estabelecer uma correlação muita clara. O que está bem definido em relação à imunologia de LTB é que sua capacidade de modular o sistema imunológico é resultante da interação com receptores GM1 presentes em células eucarióticas, incluindo leucócitos e linfócitos, posto que o mutante LTB-G33D (mutação na subunidade B que diminui a interação com receptor GM1) não foi capaz de induzir efeitos adjuvantes e perdeu características imunológicas expressas pela LTB selvagem (FRASER et al., 2003; HAAN et al., 1998; TRUITT et al., 1998; WILLIAMS et al., 1999). Além da capacidade de potencializar a resposta imunológica contra antígeno alvo, a LTB possui capacidade de imunomodulação. Em estudos empregando modelos animais para doenças autoimunes (artrite reumatoide induzida por colágeno e uveíte), a administração por vias de mucosa (intranasal ou oral) de LTB promove a proliferação de células $\mathrm{T} \mathrm{CD}^{+} \mathrm{CD} 25^{+} \mathrm{Foxp}^{+}$regulatórias e secreção de citocinas como TGF $\beta$ ou IL-10, modulando o perfil inflamatório da resposta celular autoimune para um perfil anti-inflamatório através da indução de resposta humoral (BASSET et al., 2010; DONALDSON et al., 2011; LUROSS et al., 2002; RAVENEY et al., 2008; WILLIAMS et al., 1997).

Os estudos das respostas imunológicas humorais induzidas por LT e seus derivados atenuados ou atóxicos se limitaram basicamente à avaliação da potência da resposta pela determinação dos títulos dos anticorpos IgG sérico e S-IgA e da modulação da resposta através da caracterização dos perfis de subclasses de IgG (de HAAN et al., 1998; GIULIANI et al., 1998; SUMMERTON et al., 2009). Além disso, em alguns trabalhos o caráter protetor da ativação do sistema imunológico pelas vacinas foi analisado, sem, no entanto, se estabelecer qual aspecto da geração de anticorpos foi importante nesse processo (RYAN et al, 1999; ZOETEWEIJ et al., 2006). Poucos pesquisadores têm explorados a funcionalidade dos anticorpos relacionada à afinidade e capacidade de neutralização quando as LTs são usadas como adjuvantes (BJARNARSON et al., 2012; KATZ et al., 1997; OLAFSDOTTIR et al., 2007). Por isso se faz necessário um aprofundamento dos aspectos imunoduladores humorais desenvolvidos pelas toxinas LTs e dos mecanismos imunológicos envolvidos.

Os anticorpos ou imunoglobulinas são glicoproteínas produzidas por linfócitos B e estruturalmente são formados por cadeias pesada e leve ligadas por pontes dissulfetos. Esta interação divide os anticorpos em duas regiões: variável - região de ligação com os antígenos (Fab - Fragment antigen binding), e constante - região de ligação com receptores específicos presentes na superfície de células do sistema imunológico (Fc - Fragment crystallizable) (Figura 2). Os anticorpos são divididos em cinco classes ou isotipos: IgM, IgD, IgG, IgA e IgE. A classe IgG é formada por quatro subclasses (IgG1, IgG2, IgG3, IgG4) e IgA por duas 
subclasses (IgA1 e IgA2) (MURPHY et al., 2008). A atuação dos anticorpos é fundamental para a proteção do hospedeiro contra patógenos extra e intracelulares ou contra produtos tóxicos liberados por esses microrganismos. A funcionalidade in vivo desses componentes da resposta humoral adquirida depende da amplitude da resposta gerada (níveis séricos e locais) e da especificidade e afinidade ao antígeno alvo, bem como da participação dessas substâncias em processos envolvendo a atividade conjunta com os componentes da resposta imunológica inata. Desta interação com outros componentes do sistema imune são desencadeados mecanismos efetores, incluindo opsonização promovendo à ativação de células fagocíticas por meio da interação da porção Fc dos anticorpos a receptores específicos presentes na superfície destas células; citotoxicidade celular dependente de anticorpos (ADCC - antibody dependent cell mediated cytotoxicity), anticorpos ligam-se em antígenos presentes na superfície de células infectadas e promove a ativação de células matadoras profissionais (NK - natural killers) que por sua vez, liberam substâncias desencadeadoras de morte da célula infectada; ativação da via clássica do sistema complemento por meio da interação com o componente C1, também são capazes de ligar e neutralizar patógenos, como por exemplo, vírus impedindo à interação destes com células do hospedeiro e substâncias estranhas produzidas por microrganismos como, por exemplo, toxinas bacterianas (ABBAS; LICHTMAN, 2005; MURPHY et al., 2008).

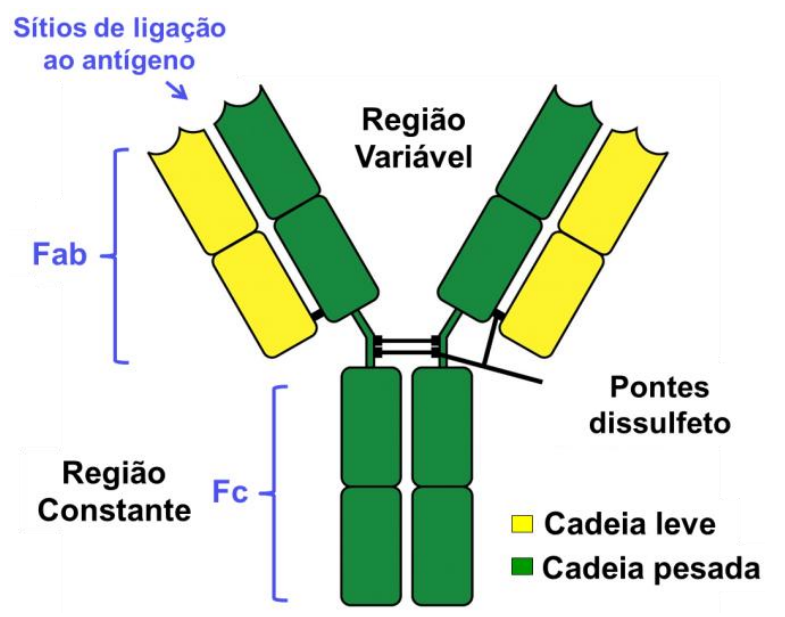

Figura 2. Representação esquemática da estrutura dos anticorpos. As moléculas de anticorpos são formadas por duas cadeias pesadas (verde) e duas cadeias leves (amarelo), ligadas por pontes dissulfeto. Os anticorpos apresentam a região variável contendo o sítio de ligação ao antígeno denominada de Fab, e região constante $\mathrm{Fc}$ responsável pela interação con receptores específicos e presentes na superfície das células do sistema imunológico. Fonte: Modificado de Murphy et al.. 2008 .

Diversos estudos ressaltaram a importância do padrão de glicosilação dos anticorpos IgG na sua estabilidade estrutural e função efetora (ARNOLD et al., 2007; JEFFERIS; LUND, 2002; JEFFERIS, 2005). A glicosilação dos anticorpos ocorre em processo pós- 
traducional por ação de enzimas da família glicosiltransferases presentes no retículo endoplasmático e complexo de Golgi. Aproximadamente $20 \%$ da glicosilação está presente na porção Fab, e $80 \%$ está presente na porção Fc dos anticorpos (Figura 3). As cadeias de carboidratos tem um importante papel na estrutura dos anticorpos, mantem a solubilidade, conformação estrutural, facilitam o transporte subcelullar, secreção, eliminação pelo organismo e particularmente influenciam nas funções efetoras dos anticorpos (ARNOLD et al., 2007). Os padrões de glicosilação geralmente encontrados na estrutura dos anticorpos apresentam um núcleo heptamérico constante contendo resíduos de manose e $\mathrm{N}$ acetilglicosamina, no qual são inseridos resíduos variáveis como, por exemplo, fucose, galactose e ácido siálico (Figura 4) (BÖHM et al., 2012).

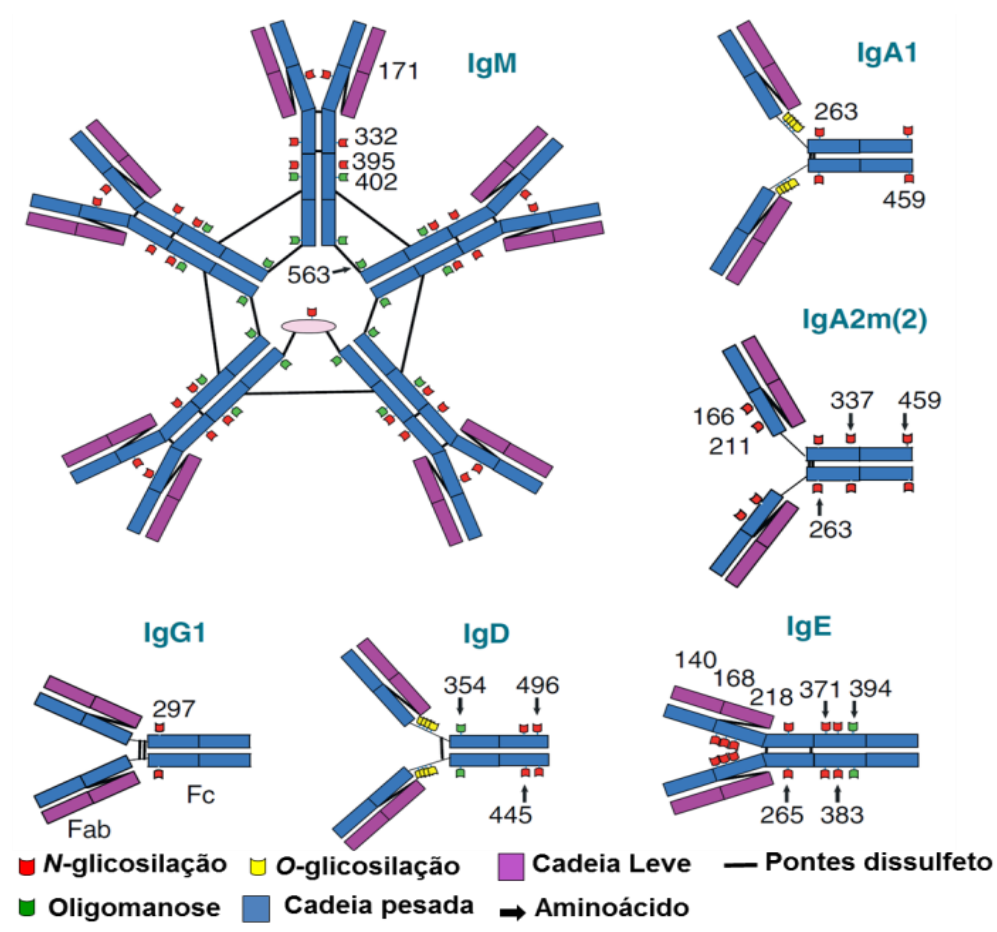

Figura 3. Representação esquemática dos sítios de glicosilação na estrutura de anticorpos IgM, IgD, IgG1, IgA1, IgA2m (2) e IgE. As cadeias de carboidratos presentes na estrutura dos anticorpos podem ser do tipo $N$-glicosiladas (cadeias de carboidratos ligad as ao aminoácido asparagina) e $O$-glicosiladas (cadeias de carboidratos ligadas ao aminoácido serina ou treonina). Cerca de $20 \%$ da glicosilação está presente na porção Fab e $80 \%$ na porção Fc. Fonte: Modificado de Arnold et al., 2007. 


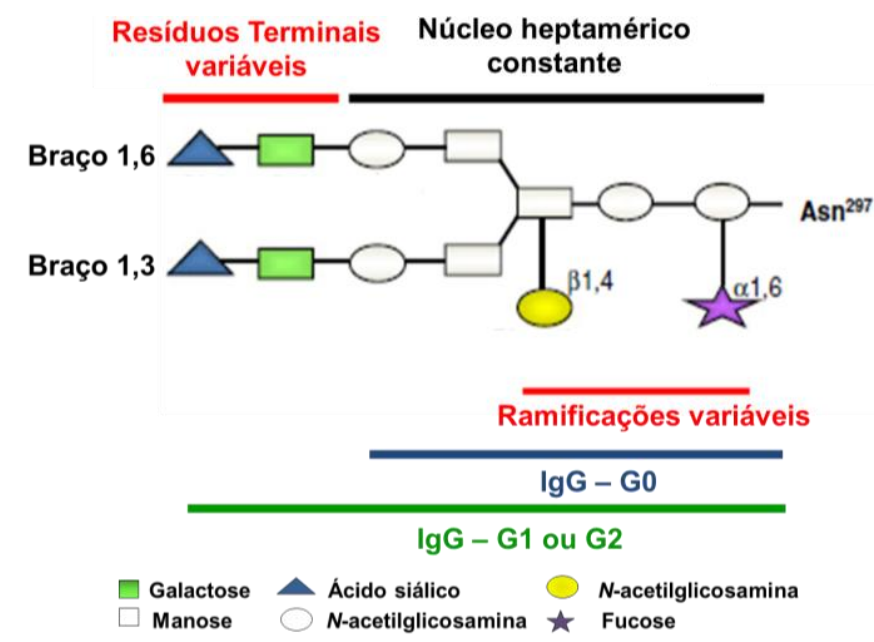

Figura 4. Composição das cadeias de carboidratos. As cadeias de carboidratos são formadas por um núcleo heptamérico biantenário constante, no qual, são inseridos resíduos de carboidratos: galactose (G0, G1 ou G2), ácido siálico, fucose, $N$ acetilglicosamina, entre outros. Fonte: Modificado de Böhm et al., 2012.

A A glicosilação de anticorpos ocorre de maneira heterogênea e é influenciada por diferentes fatores como idade, sexo e condição de saúde do indivíduo (ITOH et al., 1993; YAMADA et al., 1997), mas também pode ser modulada por processos de imunizações naturais ou artificiais. Dentro deste contexto, Guo e colaboradores (2005), com intuito de investigar a possibilidade de imunizações repetidas alterarem o perfil de glicosilação de anticorpos, analisaram a composição de oligossacarídeos $N$-ligados aos anticorpos IgG ovalbumina-específicos obtidos de camundongos previamente imunizados com diferentes quantidades de reforço antigênico. Como resultado, observaram que depois de repetidas imunizações com antígeno, os anticorpos IgG específicos apresentaram progressivamente aumento do conteúdo de resíduos de fucose $N$-ligados à molécula, sugerindo que esta alteração poderia apresentar importante significância biológica. Anticorpos IgG1 humanos defucosilados (sem resíduos de fucose) apresentaram maior afinidade aos receptor Fc $\gamma$ RIII expressos em células NK, melhorando a citotocixidade mediada pelo anticorpo (SHIELD et al., 2002; SHINKAWA et al, 2003). Recentemente, Silva e colaboradores (2008) demonstraram que anticorpos monoclonais IgG1 com maior conteúdo de ácido siálico na região Fc do anticorpo apresentam alta afinidade aos receptores FcyRIII expressos na superfície de mastócitos, o que repercutiu na capacidade dessa molécula em induzir reação anafilática. Além da fucose e do ácido siálico, outros carboidratos tem demonstrado capacidade de modulação da função efetora de anticorpos para um perfil anti-inflamatório ou pró-inflamatório, baseado na capacidade desses anticorpos reconhecerem receptores 
inibitórios ou estimulatórios na superfície de células da imunidade inata, respectivamente (Tabela 2). Tais estudos evidenciam a importância do perfil de carboidrato dos anticorpos na sua funcionalidade.

A presença ou ausência de toda a cadeia de carboidrato ligada ao anticorpo também pode afetar sua ação efetora. Anticorpos derivados de seres humanos infectados pelo vírus HIV e tratados com enzima endoglicosidase PNGase F apresentaram diminuição da interação com receptores FcyIIIA presentes em células NK em ensaio in vitro, causando impacto na atividade antiviral (ACKERMAN et al., 2013). A presença de estruturas glicosiladas em fragmentos de cadeias variáveis (VHH - chain fragmente variable) de anticorpos de lhamas conferiu uma maior capacidade desses anticorpos em neutralizar a ação da toxina LT em ensaio in vitro (HARMSEN et al., 2009). Diante do exposto, fica evidente a importância da glicosilação na função dos anticorpos e a necessidade de estudos que visam esclarecer a influência de substância adjuvante, como LTs e seus derivados, na modulação da glicosilação dos anticorpos durante a sua síntese pelas células $\mathrm{B}$ e, consequentemente, nas diversas funções efetoras desenvolvidas por essas moléculas.

Tabela 2. Influência dos carboi dratos encontrados na porção Fc de Ig G na funcionalidade desse isotipo de anticorpo.

\begin{tabular}{cccc}
$\begin{array}{c}\text { Tipo de } \\
\text { carboidrato }\end{array}$ & $\begin{array}{c}\text { Presença ou } \\
\text { ausência }\end{array}$ & $\begin{array}{c}\text { Perfil de modulação } \\
\text { em anticorpos IgG }\end{array}$ & Refe rências \\
\hline Fucose & - & Pró-inflamatório & SHIELD et al., 2002 \\
& & Anti-inflamatório & SHINKAW et al., 2003 \\
Ácido siálico & + & Pró-inflamatório & BÖHM et al., 2012 \\
Galactose & - & Pró-inflamatório & BÖHM et al., 2008 \\
Manose & + & Anti-inflamatório & GOETZ et al., 2011 \\
\hline
\end{tabular}

A dengue é uma doença causada por um arbovírus pertencente à família Flaviviridae do gênero Flavivirus e é transmitida através do vetor conhecido como Aedes aegypti. Em torno de 100 milhões de pessoas de regiões tropical e subtropical são acometidas por essa doença e destas um milhão pode desenvolver uma forma grave da doença denominada febre da dengue hemorrágica (DHF - dengue haemorrhagic fever) (CARDOSA, 1998; HOLMES, 2009). Na maioria dos casos a infecção desencadeada pelo vírus da dengue é assintomática. No entanto, a patologia pode se manifestar através de sinais de febre alta e intermitente, dores de cabeça, mialgia, artralgia, vômitos e dor abdominal aguda, podendo ser confundidos com sintomas gripais. Isso se deve ao fato do vírus inicialmente infectar células musculares 
estriadas e lisas, fribroblastos, células imatura de Langerhans (células dendríticas) e queratócitos. A progressão da doença afeta os linfonodos, permitindo que o vírus atinja a circulação linfática e sanguínea e se dissemine por todo o organismo no interior de diversas células imunológicas (monócitos, macrófagos, leucócitos, células dendríticas e mielóides) (FIGUEIREDO, 1999a; MARTINA; KORAKA; OSTERHAUS, 2009). Dessa forma, ocorrem os caso mais graves, que se caracterizam por coagulopatia, aumento da fragilidade e permeabilidade vascular, sangramentos da gengiva e aparecimento de petéquias (DHF). Com a progressão da DHF pode-se observar o desenvolvimento da Sínd rome do Choque da dengue (DSS - dengue shock syndrome), onde as manifestações clínicas mais características são encefalite, insuficiência hepática, miocardite e coagulação intravascular disseminada, o que leva aos sintomas de sangramento maciço, hipotensão, acidose metabólica, leucopenia, entre outros (MALAVIGE et al., 2004).

Atualmente se conhece 4 tipos de vírus da dengue (DEN1 a DEN4), que apresentam entre si em torno de $30 \%$ de divergência na sequência de nucleotídeos dos seus genomas. $\mathrm{O}$ vírus da dengue é envelopado e apresenta RNA de fita simples com polaridade positiva e com 10 genes. Após processos de tradução a partir do RNA viral é liberada uma poliproteína que quando clivada gera três proteínas estruturais de envelope, membrana e capsídeo (E envelope protein, $\mathrm{M}$ - membrane protein e $\mathrm{C}$ - capsid protein) e sete proteínas não estruturais (NS1-non structural proteins, NS2a, NS2b, NS3, NS4a, NS4b e NS5). A proteína E está presente no envelope viral e apresenta variação de sequência de aminoácidos entre os diferentes sorotipos, por isso é considerada um importante fator antigênico do vírus. A proteína E (53 kDa) é glicosilada e possui duas subunidades compostas cada uma por três regiões: I (presente na região central da molécula), II (maior parte do dímero) e III (porção Cterminal responsável pela virulência). É através do domínio III que a proteína E interage com os receptores de superfície das células hospedeiras, permitindo a entrada do vírus por pinocitose (FIGUEIREDO, 1999a, b; MALAVIGE et al., 2004; PEREIRA; KUNH, 2008).

Em relação às respostas imunológicas dirigidas contra o vírus da dengue, a resposta humoral apresenta papel importante tanto através dos processos de neutralização que evitariam a entrada do patógeno na célula hospedeira como por eventos de citotoxidade mediada por anticorpos que eliminaria as células já infectadas pelos vírus. Durante a infecção pelo vírus da dengue, a defesa do hospedeiro inicia-se com produção de anticorpos específicos a epítopos presentes em toda a superfície da proteína E, ocasionando neutralização das regiões I e II, o que impede a formação de trímeros, e da região III, que bloqueia a ligação do vírus a membrana celular hospedeira. São produzidos inicialmente anticorpos da classe 
IgM, que decresce após alguns dias de infecção, e anticorpos IgG que permanecem detectáveis durante alguns anos. Adicionalmente, ocorre também indução de resposta imunológica citotóxica mediada por linfócitos T com consequente lise das células infectadas pelo vírus e ativação de linfócitos T auxiliares produtores de INF- $\gamma$, IL-2 e fator estimulador de colônias de granulócitos e macrófagos (FIGUEIREDO, 1999a; MARTINA; KORAKA; OSTERHAUS, 2009). No entanto, a real influência das respostas efetoras humorais ou celulares sobre a proteção contra a doença desencadeada pelo vírus da dengue permanece ser determinada.

As ações desencadeadas pelos anticorpos podem ser moduladas pelos padrões de glicosilação presentes nestas moléculas. Estes padrões são influenciados pelas condições fisiológicas ou patológicas dos indivíduos e também podem sofrer alterações via mecanismos extrínsecos como processo de imunização (GUO et al., 2005; JOHNSON et al., 2013; RAJU, 2008). As pesquisas atuais relacionadas à análise da glicosilação dos anticorpos direcionam seus estudos na investigação do papel destes carboidratos nas terapias com imunoglobulina intravenosa ou em processos inflamatórios causados por doenças autoimunes (artrite reumatoide, trombocitopenia autoimune), ou em processos patológicos como infecções pelo vírus HIV (ACKERMAN et al., 2013; ANTHONY et al., 2012; COLLIN; EHLERS, 2013; SHADE; ANTHONY, 2013). Atualmente, não há trabalhos publicados propondo investigar a influência da LT, ou de qualquer outro adjuvante, na modulação dos perfis de glicosilação dos anticorpos gerados, que por sua vez, possam interferir na interação específica aos antígenos e na habilidade dos anticorpos em ativarem células do sistema imune inato via interação com receptores da porção Fc. Desta forma, a caracterização dos perfis diferenciados de glicosilação dos anticorpos mediada por adjuvantes precisa ser investigada, para que se tenha um entendimento preciso das potencialidades de um adjuvante e a sua capacidade de induzir uma resposta humoral protetora. 


\section{OBJETIVO}

A presente dissertação teve como principal objetivo avaliar as propriedades imunomoduladoras da enterotoxina termo-lábil de E. coli (LT1) e de seus derivados não tóxicos (LT1-B e LT1-K63), analisando a capacidade desses adjuvantes em potencializar a produção de anticorpos IgG séricos específicos, regular a produção de diferentes subclasses de IgG, influenciar na capacidade funcional dos anticorpos (afinidade e capacidade de neutralização viral) e modular os perfis de glicosilação dos anticorpos IgG antígenoespecíficos gerados. Para esse intuito, foi utilizado como antígeno alvo o domínio III da proteína E (EIII) do vírus da dengue tipo 2 (DENV2). 


\section{MATERIAL E MÉTODOS}

\subsection{Clonagem do gene eltB em vetor de expressão pET22b}

A amplificação do gene elt B que codifica para a subunidade B da proteína LT1, foi realizada através da técnica de reação em cadeia da polimerase (PCR), utilizando os iniciadores contendo sítios de restrição NdeI e XhoI: FwNdeI 5'-CAG AAG GCG GAA TGA CAT ATG AAT AA-3' e RvXhoI 5'-TTA AAA GCA TGT CTC TCG AGA GAA CC- 3'. Esses iniciadores foram desenhados a partir da sequência de nucleotídeos do gene eltB presente no banco de dados genbank GI: 408994 codificante para a proteína LT1 de Escherichia coli enterotoxigênica de referência H10407 (LASARO et al., 2009). O produto da PCR purificado por kit (GE Healthcare Illustra GFX) foi ligado no vetor comercial de

subclonagem pGEM (pGEM T Easy Vector Systems - Promega) de acordo com as especificações do fabricante. Em seguida, a mistura de ligação foi utilizada na transformação de células Escherichia coli DH5 a quimiocompetentes, que posteriormente foram crescidas em placas de ágar Luria Bertani (LB) contendo ampicilina $(100 \mu \mathrm{g} / \mathrm{mL})$. A clonagem foi confirmada por análise do perfil de digestão gerados com as enzimas NdeI e XhoI (FermentasThermo Scientific) em gel de agarose $0,8 \%$.

Posteriormente, foi realizada uma nova digestão do plasmídeo pGEM-LT1-B para obtenção de mais inserto. O inserto foi purificado do gel de agarose por kit (GE Healthcare Illustra GFX) e o produto obtido foi inserido no vetor de expressão pET22b (Novagen, Darmstadt Alemanha), previamente digerido com as enzimas NdeI e XhoI. Células de Escherichia coli $\mathrm{DH} 5 \alpha$ quimiocompetentes foram transformadas com o produto de ligação e a confirmação dos clones obtidos foi realizada por digestão do plasmídeo recombinante com as endonucleases acima citadas e sequenciamento do gene $e l t B$ através da técnica de interrupção de síntese com dideoxinucleotídeos marcados com fluorocromos. Utilizou-se o sequenciador automático (ABI 377, Perkin-Elmer Applied Biossystems) disponível no departamento de Bioquímica/FCF da USP e reagentes do kit comercial "Big Dye terminator DNA sequecing" (Applied Biosystem). O plasmídeo recombinante contendo o gene elt $B$ foi denominado pET22b-LT1-B, e foi utilizado na transformação de células de Escherichia coli BL21 DE03 pLys competentes para expressão da proteína LTB. A linhagem produtora de LT1-B foi mantida em estoque contendo $30 \%$ de glicerol como crioprotetor e armazenadas a $-80{ }^{\circ} \mathrm{C}$. 


\subsection{Expressão e purificação da proteína LT1-B recombinante}

\subsubsection{Expressão da proteína LT1-B}

Uma alíquota do estoque congelado de E. coli BL21 DE03 pLys contendo o plasmídeo pET22b-LT1-B foi inoculada em $50 \mathrm{~mL}$ de caldo LB contendo ampicilina (100 $\mu \mathrm{g} / \mathrm{mL})$ e o pre-inóculo foi acondicionado em um erlenmeyer de $250 \mathrm{~mL}$ e incubado a $37{ }^{\circ} \mathrm{C}$, sob agitação de $200 \mathrm{rpm}$ em agitador orbital por aproximadamente 18 horas. Esta cultura foi utilizada como pré-inóculo com diluição inicial de 1:100 para 4 L de meio Luria-Bertani (LB) distribuídos em 4 erlenmeyers e o inóculo final foi incubado a $37{ }^{\circ} \mathrm{C}$ sob agitação de $200 \mathrm{rpm}$ até a fase de crescimento exponencial $\left(\mathrm{DO}_{600 \mathrm{~nm}}=0,5-0,6\right)$, quando foi acrescentado à cultura o indutor isopropil $\beta$-D-1 tiogalactopiranosideo (IPTG-isopropyl $\beta$-D-1 thiogalactopyranoside) na concentração final de $0,75 \mathrm{mM}$. A cultura induzida foi mantida sob as condições descritas anteriormente por mais 6 horas. Após esse período a cultura foi centrifugada a 10.000 x g por 30 minutos a $4{ }^{\circ} \mathrm{C}$. Alíquotas coletadas antes e após a indução foram aplicadas em gel SDSPAGE $17,5 \%$ para verificar a presença de proteína induzida.

A massa bacteriana obtida foi ressuspensa em $400 \mathrm{~mL}$ de tampão TEAN sem sal (TrisHCL 0,5 M, EDTA 0,01 M, NaN $30,03 \mathrm{M}, \mathrm{pH} 7,4)$. O extrato bacteriano passou por lise à alta pressão (600 psi) utilizando o aparelho homogeneizador (APLAB 10 - Arte peças) durante 2 minutos. O homogenato obtido foi clarificado por centrifugação a 10.000 x g por 1 hora a 4 ${ }^{\circ} \mathrm{C}$. O sobrenadante foi filtrado com pré-filtros de 0,22 $\mu \mathrm{m}$ da marca Millipore. A amostra obtida ao final desse processo denominou-se homogenato clarificado e foi aplicada à coluna de cromatografia de afinidade.

\subsubsection{Purificação da proteína LT1-B}

A proteína LT1-B foi purificada através de cromatografia de afinidade em resina Galactose-gel (Pierce, Immobilized D-Galactose Gel) empacotada em coluna XK 16/20 da Amersham Biosciences $(1,6 \mathrm{~cm} \varnothing$ e $20 \mathrm{~cm}$ altura). O processo de purificação automatizado foi realizado em aparelho AKTA - FPLC (Pharmacia). A coluna foi previamente equilibrada com 5 volumes de coluna (vc) de tampão TEAN com sal (Tris-HCL 0,5 M, EDTA 0,01 M, $\mathrm{NaN}_{3}$ 0,03 M, NaCl2,0 M, pH 7,4).O homogenato clarificado (500 mL) foi aplicado à coluna em um fluxo de $0,4 \mathrm{~mL} /$ minuto. A coluna foi lavada novamente com 5 vc de tampão TEAN 
com sal e foi iniciada a eluição das proteínas adsorvidas à coluna atra vés da injeção de $100 \%$ de TEAN com sal acrescido de 0,3 M de D-galactose. A coluna foi regenerada com $5 \mathrm{vc}$ de solução contendo uréia $6 \mathrm{M}, 5 \mathrm{vc}$ de água ultrapura e $5 \mathrm{vc}$ de água contendo $20 \%$ de etanol. Amostra, correspondente ao pico obtido, foi dialisada e concentrada em filtros Amicon Ultra15 10.000 MWCO (Millipore) em tampão TEAN com sal para a retirada do eluente Dgalactose. A análise de pureza da proteína foi observada em gel de poliacrilamida a 17,5 \%. A quantificação da concentração de LT1-B purificada foi analisada através da medida de absorbância em espectrofotômetro (Gene Quant spectrophotomer GE Amershan Biosciences), segundo procedimento descrito por Edelhoch (1967).

\subsection{Expressão e purificação das proteínas LT1 e LT1-K63}

Uma alíquota do estoque congelado da linhagem recombinante contendo o plasmídeo que codifica para proteína LT1 ou LT1-K63 (RODRIGUES et al, 2010) foi inoculada em 50 $\mathrm{mL}$ de caldo Terrific Broth (TB) contendo ampicilina $(200 \mu \mathrm{g} / \mathrm{mL})$ e o pré-inóculo foi acondicionado em um erlenmeyer de $250 \mathrm{~mL}$ e incubado a $37^{\circ} \mathrm{C}$, sob agitação de $200 \mathrm{rpm}$ em agitador orbital por aproximadamente 18 horas. A cultura foi utilizada como pré-inóculo com diluição inicial de 1:100 para 3 L de meio TB distribuídos em 4 erlenmeyers e o inóculo final foi incubado a $37{ }^{\circ} \mathrm{C}$ sob agitação a $230 \mathrm{rpm}$ em agitador orbital por aproximadamente 22 horas. Após esse período de incubação a cultura foi centrifugada a 10.000 x g por 30 minutos a $4{ }^{\circ} \mathrm{C}$. O processo de lise celular, clarificação e purificação das proteínas LT1 ou LT1-K63, foram realizados como descrito anteriormente para obtenção da proteína LT1-B. Amostra correspondente ao pico obtido para cada LT foi dialisada e concentrada em filtros Amicon Ultra-15 30.000 MWCO (Millipore) em tampão TEAN com sal para a retirada do eluente Dgalactose. A análise de pureza da proteína foi observada em gel de poliacrilamida a 17,5\%. A quantificação da concentração de LT1 ou LT1-K63 foi analisada através da medida de absorbância em espectrofotômetro (Gene Quant spectrophotomer GE Amershan Biosciences) segundo procedimento descrito por Edelhoch (1967). 


\subsection{Expressão e purificação da proteína EIII}

\subsubsection{Expressão da proteína EIII}

Os protocolos de expressão, renaturação e purificação da proteína EIII foram baseados em Amorim e colaboradores (2010). Uma alíquota do estoque congelado da linhagem recombinante E. coli BL21 DE03 contendo o plasmídeo que codifica para proteína EIII foi inoculada em $50 \mathrm{~mL}$ de caldo LB contendo canamicina $(50 \mu \mathrm{g} / \mathrm{mL})$ e o pré-inóculo foi acondicionado em um erlenmeyer de $250 \mathrm{~mL}$ e incubado a $37{ }^{\circ} \mathrm{C}$ sob agitação de $200 \mathrm{rpm}$ em agitador orbital por aproximadamente 18 horas. A cultura foi utilizada como pré-inóculo com diluição inicial de 1:100 para $4 \mathrm{~L}$ de LB, que foram distribuídos em 4 erlenmeyers e incubados a $37{ }^{\circ} \mathrm{C}$ sob agitação de $200 \mathrm{rpm}$ até a fase de crescimento exponencial $\left(\mathrm{DO}_{600 \mathrm{~nm}}=\right.$ 0,5-0,6), quando foi acrescentado à cultura o indutor IPTG na concentração final de $0,5 \mathrm{mM}$. A cultura induzida foi mantida sob as condições descritas anteriormente por mais 4 horas. Após esse período, a cultura foi centrifugada a 10.000 x g por 30 minutos a $4{ }^{\circ} \mathrm{C}$. A massa bacteriana obtida foi ressuspensa em $400 \mathrm{~mL}$ de em tampão A (fosfato de sódio $0,1 \mathrm{M}, \mathrm{NaCl}$ 0,5 M, $20 \%$ de glicerol, pH 6,5). As células foram lisadas por homogeneização à alta pressão (600 psi) utilizando o aparelho homogeneizador durante 10 minutos. $\mathrm{O}$ homogenato obtido foi clarificado por centrifugação a 10.000 x g por 1 hora a $4{ }^{\circ} \mathrm{C}$. O sobrenadante foi descartado e a amostra decantada, contendo proteína EIII insolúvel em corpúsculo de inclusão, foi submetida a uma condição desnaturante com a adição de $10 \mathrm{~mL} / \mathrm{L}$ de cultura do tampão desnaturante (fosfato de sódio $0,1 \mathrm{M}, \mathrm{NaCl} 10,5 \mathrm{M}, \mathrm{pH}$ 6,5, uréia $8 \mathrm{M}$ ) e incubada por 18 horas a $4{ }^{\circ} \mathrm{C}$.

\subsubsection{Renaturação da proteína EIII por diluição pulsada}

O extrato resultante da solubilização dos corpúsculos de inclusão foi centrifugado a 9.000 x g por 40 minutos a $4{ }^{\circ} \mathrm{C}$. Para a renaturação da proteína EIII, $10 \mathrm{~mL}$ de extrato solubilizado em tampão desnaturante foram submetidos à diluição pulsada com auxílio de bomba peristáltica em velocidade de rotação suficiente para gotejamento de $250 \mu \mathrm{L} / \mathrm{min}$ em 2 L de tampão A (fosfato de sódio 0,1 M, NaCl 0,5 M, $20 \%$ de glicerol, pH 6,5) sob agitação constante de $60 \mathrm{rpm}$. Após renaturação, a amostra foi novamente centrifugada e filtrada em pré-filtros de $0,22 \mu \mathrm{m}$ da marca Millipore. 


\subsubsection{Purificação da proteína EIII}

A amostra foi aplicada em coluna His-Trap HP $5 \mathrm{~mL}$ (GE Healthcare Life Sciences) em função da ligação da cauda de histidina da proteína à resina de níquel. O processo de purificação foi realizado em aparelho AKTA - Avant (GE Healthcare Life Sciences). A coluna foi previamente equilibrada com 5 vc com tampão A. A amostra $(2 \mathrm{~L})$ foi aplicada à coluna em um fluxo de $2 \mathrm{~mL} /$ minuto, em seguida a coluna foi lavada novamente com $100 \mathrm{~mL}$ de tampão A e foi iniciado o processo de eluição das proteínas adsorvidas à coluna sob utilização de um gradiente linear de imidazol (0 a $100 \%)$ a partir da mistura do tampão A com o tampão B (fosfato de sódio $0,1 \mathrm{M}, \mathrm{NaCl} 0,5 \mathrm{M}, 1 \mathrm{M}$ de imidazol, $20 \%$ de glicerol, pH 6,5). A coluna foi regenerada com 5 vc de tampão B e lavada com mais 5 vc de tampão A, 5 vc de água ultrapura e 5 vc com solução contendo $20 \%$ de etanol. Amostras correspondentes aos picos obtidos foram aplicadas em SDS-PAGE 17,5 \% e as frações escolhidas foram concentradas em filtros Amicon Ultra-15 3.000 MWCO (Millipore) em tampão A para a retirada do eluente imidazol. A amostra final com EIII purificada foi quantificada através da medida de absorbância em espectrofotômetro (Gene Quant spectrophotomer GE Amershan Biosciences) segundo procedimento descrito por Edelhoch (1967).

\subsection{Remoção e quantificação de lipolissacarídeo (LPS) presente nas proteínas utilizadas na imunização}

O protocolo para a remoção do lipolissacarídeo (LPS), presente nas proteínas recombinantes proveniente do sistema de expressão em linhagens comerciais de Escherichia coli (gram-negativa), foi realizado por kit utilizando resina de poli-lisina $\varepsilon$ seguindo as especificações do fabricante (Pierce ${ }^{\circledR}$ High-Capacity Endotoxin Removal Resin Thermo Scientific). Para a remoção de LPS a proteína EIII foi mantida no tampão fosfato de sódio a $50 \mathrm{mM}, \mathrm{NaCl}$ 0,2 M, pH 6,0 e as proteínas LT1, LT1-B e LT1-K63 no tampão fosfato de sódio a $50 \mathrm{mM}, \mathrm{NaCl}$ 0,2 M, pH 7,4. A concentração de endotoxina (EU - unidade endotóxica) presente nas proteínas tratadas foi determinada empregando o kit Limulus Amebócyte Lysate LAL QCL-1000 (Lonza). As amostras apresentaram quantidades <0,02 EU/ug de proteína, abaixo dos valores permitidos para formulações vacinais utilizando proteínas recombinantes < 3.6 EU/100 $\mu \mathrm{L}$ da formulação vacinal (PADMA; SINGH, 2008). 


\subsection{Ensaio de imunização}

Camundongos fềmeas das linhagens Balb/c, C57BL/6 selvagens ou C57BL/6 nocautes para receptores do tipo toll 4 (TLR4 - Toll-like receptor 4 ) com 6 a 8 semanas de idade, foram utilizados para os ensaios de imunização e foram obtidos junto ao Biotério de Isogênicos da Parasitologia-ICBII/USP(Comissão de Ética no uso de animais (CEUA) $n^{\circ}$ 198). O protocolo de imunização consistiu da administração subcutânea em 3 doses com intervalo de 14 dias. Cada dose inoculada nos animais consistiu de $100 \mu \mathrm{L}$ de PBS contendo $10 \mu \mathrm{g}$ da proteína EIII administrada sozinha ou em combinação com $1 \mu \mathrm{g}$ de LT1, 1 ou $5 \mu \mathrm{g}$ de LT1-K63, 1 ou 3,2 $\mu$ g LT1-B ou 12,5 $\mu$ g Alúmen (gel adsorvente de hidróxido de alumínio comercializado pela empresa Reheis). O sangue foi coletado um dia antes de cada dose e duas semanas após a última dose. Os soros dos animais foram recolhidos após a coagulação do sangue a $37{ }^{\circ} \mathrm{C}$ por 30 minutos e retração do coágulo a $4{ }^{\circ} \mathrm{C}$ por 30 minutos, seguida de centrifugação refrigerada a 3.000 x g por 15 minutos. As amostras de soros foram estocadas a $-20{ }^{\circ} \mathrm{C}$ até realização de ensaio imunoenzimático ligado à enzima (ELISA - Enzyme Linked Immunosorbent Assay) ou ensaios de neutralização e afinidade dos anticorpos.

\subsection{Titulação de anticorpos anti-EIII por ELISA}

Poços alternados de uma microplaca de poliestireno Maxisorp (Nunc) foram sensibilizados por $18 \mathrm{~h}$ a $4{ }^{\circ} \mathrm{C}$ com proteína EIII $(1 \mu \mathrm{g} / \mathrm{mL})$. As placas foram lavadas três vezes com PBS $1 x$ contendo 0,05\% de Tween-20 (PBST). Após a lavagem foi feito o bloqueio adicionando-se $200 \mu \mathrm{L}$ da solução gelatina a 3\% em PBST, e as placas foram incubadas durante $1 \mathrm{~h}$ a $37^{\circ} \mathrm{C}$. Após novo ciclo de lavagem $(3 \mathrm{x}), 100 \mu \mathrm{L}$ dos soros individuais diluídos foram adicionados aos poços e incubados a temperatura ambiente por $1 \mathrm{~h}$ e $30 \mathrm{~min}$. Depois de um novo ciclo de lavagem $(3 \mathrm{x})$, foram adicionados $100 \mu \mathrm{L}$ do segundo anticorpo anti-IgG total ou anti-IgG2a aos poços na diluição de 1/3.000 ou anti-IgG1 na diluição de 1/10.000 conjugados a peroxidase (Sigma). Em seguida, as placas foram lavadas 3 vezes com PBST e a revelação foi realizada com $100 \mu \mathrm{L} /$ poço da solução reveladora por 10 minutos a temperatura ambiente e a reação foi interrompida com $50 \mu \mathrm{L}$ por poço de ácido sulfúrico a 1 M. A leitura da densidade óptica foi realizada a $492 \mathrm{~nm}$ em leitor de placa (Multiscan MS- Labsystems). Para calcular os títulos de anticorpos EIII-específicos foi realizada análise de regressão linear $\left(\mathrm{R}^{2}>0,96\right)$. 


\subsection{Ensaio de afinidade com os anticorpos EIII-específicos}

Para o ensaio de afinidade, os soros correspondentes a cada grupo de animais imunizados foram avaliados para a determinação do título de IgG total anti-EIII por ensaio de ELISA e foram normalizados para uma D.O. de 0,5. Para a dissociação dos anticorpos antiEIII, foram empregadas várias concentrações de tiocianato de amônio diluído em PBS $(0.0 \mathrm{M}$, $0.025 \mathrm{M}, 0.05 \mathrm{M}, 0.1 \mathrm{M}, 0.2 \mathrm{M}, 0.4 \mathrm{M}, 0.6 \mathrm{M}, 0.8 \mathrm{M}, 1.0 \mathrm{M}, 2.0 \mathrm{M}$ ou $4.0 \mathrm{M})$ e as placas foram incubadas por 15 minutos a temperatura ambiente. Em seguida, foi adicionado o segundo anticorpo anti-IgG conjugado à peroxidase (Sigma) aos poços na diluição 1/3000. Após incubação por $1 \mathrm{~h}$ as placas foram lavadas 3 vezes com PBST e a revelação foi realizada com $100 \mu \mathrm{L}$ /poço da solução reveladora (tampão $33 \mathrm{mM}$ de ácido cítrico p.H 5,0, peróxido de hidrogênio, OPD) por 20 minutos a temperatura ambiente e a reação foi interrompida com 50 $\mu \mathrm{L}$ por poço de ácido sulfúrico a $1 \mathrm{M}$. A leitura da densidade óptica foi realizada a $492 \mathrm{~nm}$ em leitor de placa (Multiscan MS-Labsystems). A concentração de tiocianato de amônio necessária para dissociar $50 \%$ da ligação do anticorpo ao antígeno foi determinada da seguinte forma: D.O. (492 nm) em presença de tiocianato de amônio nm X 100/D.O. (492 nm) em ausência de tiocianato de amônio (LASARO et al., 2009).

\subsection{Determinação da capacidade de neutralização viral dos anticorpos EIII-específico}

Os pools de soro de cada grupo de imunização foram diluídos (1/10 a 1/1280) em meio DMEM (Gibco) com antibiótico estreptomicina (1/1000). Em cada tubo de diluição foi acrescentado 80 unidades formadoras de placas (UFP) do vírus Dengue tipo II e essa mistura foi incubada por 30 minutos a $37^{\circ} \mathrm{C}$ e $5 \% \mathrm{CO}_{2}$ (AMORIM et al., 2012). Posteriormente a mistura soro/vírus correspondente a cada diluição foi adicionada em duplicata aos poços contendo monocamada de linhagem celular LLCMK2. A cada placa foi adicionado um controle positivo com 80 UFP de vírus sem soro. Após incubação de 1 hora, homogeneizando a cada 15 minutos, a mistura (soro/vírus) foi retirada de contato com a monocamada celular e foi adicionada aos poços uma mistura de meio 199 contendo $1 \%$ de soro fetal bovino (SFB), antibiótico e $1 \%$ de sal sódico de carboximetilcelulose (CMC). As placas foram embrulhadas em papel alumínio devido a sensibilidade do vírus a luz e incubadas durante 7 dias a $37^{\circ} \mathrm{C}$ e 5 $\% \mathrm{CO}_{2}$. Em seguida, foram realizadas a fixação da monocamada celular com $10 \%$ de formol e a coloração com cristal violeta, sendo possível observar a placas formadas. O soro foi 
considerado neutralizante quando reduziu o número de placas em pelo menos $50 \%$ em comparação ao controle positivo. Deve-se considerar o título neutralizante como à última diluição em que se observa redução de pelo menos $50 \%$ da formação de placas.

\subsection{Purificação dos anticorpos IgG EIII-específicos}

\subsubsection{Purificação dos anticorpos anti-EIII}

Para a purificação de anticorpos EIII-específicos, foi utilizada coluna His-Trap HP 1 ml (GE Healthcare Life Science), acoplada em aparelho AKTA - FPLC (Pharmacia). A coluna foi previamente equilibrada com 5 vc de tampão A e uma suspensão de $5 \mathrm{mg}$ de proteína EIII purificada foi aplicada à coluna em um fluxo $0,05 \mathrm{~mL} / \mathrm{minuto}$. Posteriormente a coluna foi lavada com 5 ve de tampão de ligação (fosfato de sódio 0,05 M, pH 7,4) e a suspensão de soro previamente deslipidada foi aplicada à coluna em fluxo de $0,05 \mathrm{~mL} / \mathrm{minuto}$. A coluna foi novamente lavada com 5 vc de tampão equilíbrio e foi iniciada a eluição das anticorpos EIII-específicos adsorvidos à proteína EIII, sob a utilização de $100 \%$ de tampão de eluição (glicina 0,1 M, pH 4,0). A fração eluída em tubos eppendorf contendo tampão de neutralização (Tris-HCL 1M pH 9,0), foi denominada F2. A coluna foi regenerada com 5 vc de tampão ligação, e um novo ciclo de purificação de anticorpos se repetiu, para cada grupo de soro. Por fim, a coluna foi lavada com 5 vc de água ultrapura e 5 vc com solução contendo $20 \%$ de etanol. Amostras correspondentes aos picos obtidos na fração F2 foram dialisadas em membrana de celulose (Dialysis tubing - Sigma-Aldrich) de 12 kDa em tampão PBS (pH 7,4).

\subsubsection{Purificação dos anticorpos IgG EIII-específicos}

Para a obtenção dos anticorpos IgG, amostras dos anticorpos purificados EIIIespecíficos foram aplicadas à coluna de proteína G-Sepharose $(1 \mathrm{~mL})$ acoplada ao aparelho AKTA - FPLC (Pharmacia). Etapas de purificação e diálise dos anticorpos purificados foram realizadas como descrito anteriormente. Posteriormente à diálise, as amostras de IgG EIIIespecífico foram concentradas em sistema de centriplus YM-100 (Amicon) $100 \mathrm{kDa}$ e a concentração de anticorpos foi determinada por ensaio de dosagem com proteína com kit BCA (Pierce BCA protein-Thermo Scientific). A eficiência do método de purificação foi avaliada pela técnica de ELISA e eletroforese de gel de SDS-PAGE a $15 \%$. 


\subsection{Caracterização do padrão de glicosilação dos anticorpos IgG EIII-específicos por ELISA com lectina}

A determinação dos perfis de composição de carboidratos ligados às cadeias dos anticorpos IgG anti-EIII purificados foi realizada como descrito por Silva e colaboradores (2008). A ligação às diferentes lectinas dos anticorpos IgG EIII-específicos e purificados foi avaliada por ELISA com o uso de placas de 96 poços (Maxisorp) sensibilizadas com $1 \mu \mathrm{g} / \mathrm{mL}$ de Aleuria aurantia, Lens culinaris, Maackia amurensis, Wisteria floribunda, Erythrina cristagalli, Ricinus communis Agglutinin, Concanavalin A, Ulex europaeus, Sambucus nigra, Bauhinia purpúrea ou Limulus polyphemus (Sigma-Aldrich) diluídas em PBS (pH 7,2). Após incubação por $16-18 \mathrm{~h} \mathrm{a} 4{ }^{\circ} \mathrm{C}$, as placas foram lavadas com PBST e bloqueadas com gelatina a $3 \%$ diluída em PBST por $2 \mathrm{~h}$ a $37{ }^{\circ} \mathrm{C}$. Em seguida, as placas foram novamente lavadas e os anticorpos (100 ng/poço) foram adicionados e incubados por $1 \mathrm{~h}$ a $37^{\circ} \mathrm{C}$. Após esta etapa, foi realizado o mesmo procedimento descrito anteriormente para a titulação dos anticorpos contra a proteína EIII.

\subsection{Análise de $N$-glicanos presentes na estrutura dos anticorpos IgG EIII-específicos}

Os experimentos descritos a seguir foram realizados no Laboratório de Glicobiologia do Prof. Dr. José Osvaldo Previato, na Universidade Federal do Rio de Janeiro - UFRJ, Rio de Janeiro, durante um estágio de 1 semana.

\subsubsection{Deglicosilação em condições desnaturantes}

Os anticorpos IgG anti-EIII purificados foram submetidos à deglicosilação em condições desnaturantes utilizando-se a enzima PNGase F (New England Biolabs Inc), que reconhece e cliva a ligação glicosídica em resíduos de glicanos e nitrogênio amíd ico da cadeia lateral de resíduos de Asparagina (glicanos N-ligados). Cerca de 100 ug de anticorpos liofilizados foram ressuspensos em $500 \mu \mathrm{L}$ da solução bicarbonato de amônio a $50 \mathrm{mM}$ e desnaturados pela adição de 12,5 $\mu \mathrm{L}$ de solução desnaturante (SDS $5 \%$, DTT $400 \mathrm{mM}$ ), em seguida foram aquecidos a $100{ }^{\circ} \mathrm{C}$ por $20 \mathrm{~min}$. Após as amostras serem resfriadas em temperatura ambiente, foram adicionados $500 \mu \mathrm{L}$ do tampão bicarbonato de amônio a $50 \mathrm{mM}$, $\mathrm{pH}$ 7,5, $100 \mu \mathrm{L}$ de NP-40 a $10 \%$ e finalmente, $5 \mathrm{U}$ da enzima PNGase F, as amostras foram incubadas por 18 horas a $37^{\circ} \mathrm{C}$ com agitação de $150 \mathrm{rpm}$ em agitador orbital. 


\subsubsection{Dessalinização dos $N$-glicanos liberados por ação da enzima PNGase F}

As amostras obtidas da etapa acima foram transferidas para tubos do tipo falcon e precipitadas com 2 volumes de coluna (vc) de etanol $-20{ }^{\circ} \mathrm{C}$ e centrifugadas a $5000 \mathrm{rpm}$ por 20 min a $4{ }^{\circ} \mathrm{C}$. O sobrenadante foi transferido para novo tubo falcon, liofilizado e ressuspenso em solução contendo $95 \%$ água Mili-Q + $5 \%$ de acetonitrila + 0,1\% de ácido trifluoroacético (TFA - acid trifluoroacetic). Os $\mathrm{N}$-glicanos liberados da estrutura dos anticorpos foram aplicados em cartuchos de extração de fase sólida octadecil silano C-18 (Solid Phase Extraction cartridges, Grace Davidson Discovery Sciences) e eluídos com $6 \mathrm{~mL}$ de solução $95 \%$ de água Mili-Q $+5 \%$ de acetonitrila $+0,1 \%$ de TFA. Posteriormente os N-glicanos foram congelados e liofilizados. Na próxima etapa, as amostras de carboidratos foram ressuspensas em $500 \mu \mathrm{L}$ de solução contendo 0,1 \% TFA em água Mili-Q, e aplicadas em colunas de carvão ativado (Porous Graphitized Carbograph, Grace Davidson Discovery Sciences) previamente regeneradas na solução contendo 0,1 \% TFA e água Mili-Q. As amostras foram eluídas com $6 \mathrm{~mL}$ de solução com $20 \%$ de acetonitrila, $0,1 \%$ de TFA em 80 $\%$ de água Mili-Q em tubos de ensaio, evaporadas e ressuspensas com $1 \mathrm{~mL}$ de água Mili-Q. Em seguida as amostras foram liofilizadas.

\subsubsection{Permetilação dos N-glicanos purificados}

Para a permetilação das hidroxilas livres dos $\mathrm{N}$-glicanos purificados foi utilizado o protocolo descrito por Ciucanu; Kerek (1984). As amostras foram ressuspendidas em $300 \mathrm{ul}$ de dimetilsulfóxico (DMSO) e $5 \mathrm{mg}$ de $\mathrm{NaOH}$ sob homogeneização leve e manual. Em seguida, foi acrescentado à mistura $170 \mu \mathrm{L}$ de iodeto de metila e os tubos foram incubados em banho ultrassom (Quimis) por 1 hora. Após incubação, $4 \mathrm{ml}$ de água Mili-Q e $2 \mathrm{~mL}$ de clorofórmio foram adicionados aos tubos e as amostras foram centrifugadas a $2.300 \mathrm{rpm}$ a 18 ${ }^{\circ} \mathrm{C}$ por $20 \mathrm{~min}$. Posteriormente retirou-se com cuidado a fase aquosa (água Mili-Q) e repetiuse o ciclo acima por mais 10 vezes. Em seguida, a água remanescente foi removida por processo natural de evaporação e as amostras foram submetidas à liofilização.

\subsubsection{Análise das cadeias de carboidratos por espectrometria de massa MALDI-TOF/TOF}

As amostras permetiladas foram dissolvidas em solução de metanol a $80 \%$ para análise em espectrometria de massa utilizando o método de ionização MALDI-TOF/TOF 
(Matrix Assisted Laser Desorption Ionization time of fligh tmass spectrometer) em aparelho Bruker Auto flex Speed, presente no Centro de Facilidades de Apoio a Pesquisa (CEFAP) do Instituto de Ciências Biomédicas, utilizando a matrix 2,5-ácido Dihidroxibenzóico (DHB) de acordo com protocolo obtido em Blomme e colaboradores (2011). Os resultados obtidos foram analisados pelo Prof. Dr. José Osvaldo Previato, utilizando o programa Data Explorer 4.9 Software (Applied Biosystems) AB Sciex Data Explore. A presença dos oligossacarídeos foi detectada na forma de aductos com sódio $(\mathrm{M}+\mathrm{Na})^{+}$, o que auxilia a detecção das glicoformas.

\subsection{Deglicosilação dos oligossacarídeos $N$-ligados da estrutura dos anticorpos IgG anti EIII em condições não desnaturante}

O ensaio de remoção das cadeias de oligossacarídeos N-ligados dos anticorpos IgG anti-EIII purificados foi realizada como descrito por Silva e colaboradores (2008), utilizando o tratamento com a enzima PNGase F em condições não desnaturantes de acordo com as especificações do fabricante (New England Biolabs Inc). Aproximadamente $50 \mu \mathrm{g}$ de anticorpos IgG anti-EIII foram adicionados à reação de digestão contendo $15 \mu \mathrm{L}$ de tampão acrescido de $5 \mu \mathrm{L}$ (2500 Unidades (U)) da enzima PNGase F (500.000 U/ml) e água mili-Q em quantidade suficiente para $150 \mu \mathrm{L}$ (volume final). Posteriormente a reação da digestão foi realizada a $37{ }^{\circ} \mathrm{C}$ por 24 horas em aparelho agitador basculante. A reação foi parada com a adição de 0,2 \% de solução SDS. Após as amostras de IgG EIII-específico deglicosiladas foram dialisadas e concentradas em sistema de centriplus YM-100 (Amicon) $30 \mathrm{kDa}$, e a concentração dos anticorpos foi determinada por ensaio com kit BCA (Pierce BCA proteinThermo Scientific). A eficiência do método de remoção das cadeias de oligossacarídeos Nligados foi avaliada pela técnica de ELISA com lectina Concanavalin A (Con A) com a capacidade de reconhecer as porções iniciais das cadeias de carboidratos constantes e análise em eletroforese de gel de SDS-PAGE a $12,5 \%$.

\subsection{Ensaio de ligação de anticorpos IgG anti-EIII em microchip via sistema BIAcore}

A análise da capacidade de ligação dos anticorpos IgG EIII-específicos a proteína EIII foi realizada utilizando ensaio de ressonância plasmônica de superfície (SPR) no aparelho BIAcore T100 (GE healthcare, Salt Lake City, Utah, USA), presente no Centro de Facilidades de Apoio a Pesquisa (CEFAP) do Instituto de Ciências Biomédicas. Foram 
realizadas duas estratégias envolvendo a imobilização de $1 \mu \mathrm{g}$ do antígeno EIII (estratégia 1) ou a imobilização de $30 \mathrm{ng}$ de anticorpo monoclonal anti-Fc específico para IgG de camundongos (estratégia 2) em chip CM5 (GE Healthcare), contendo dextrano carboximetilado ligado covalentemente a uma superfície de ouro. Os tampões e condições de injeção foram realizados conforme descrito por Katsamba e colaboradores (2006). Entre os experimentos $10 \mu \mathrm{l}$ de tampão de regeneração foram usados. Os sinais da superfície controle da primeira estratégia FC1 (não recoberto com a proteína EIII) foram subtraídos daqueles produzidos nas superfícies em teste FC2 (com a proteína EIII imobilizada). Para a segunda estratégia, os sinais de superfície FC3 (não recoberto com anticorpo anti-Fc de IgG de camundongo) foram descontados da superfície teste FC4 (recoberto com anticorpo antiFc de IgG de camundongo), os sinais obtidos em casa chip são necessários para produzir o sensograma expresso em unidades de ressonância ( $\Delta \mathrm{RU}$ - resonance units). Os dados foram analisados no software BIAEvaluation (v4.2, BIAcore, UF, USA).

\subsection{Análises estatísticas}

As análises de variância (ANOVA) foram realizadas com subsequente teste de Tukey's. A significância estatística foi considerada quando $p<0,05, p<0,01$ e p $<0,001$. Em alguns resultados foram aplicados Teste $t$ (não paramétrico) com subsequente uso do teste Two-trail. Nesse caso, a significância estatística foi considerada quando $\mathrm{p}<0,05$. 


\section{RESULTADOS}

\subsection{Clonagem do gene eltB em vetor de expressão pET22b e expressão da proteína recombinante LT1-B}

A sequência nucleotídica que codifica para a proteína LT1-B foi amplificada a partir do plasmídeo pML19 que codifica para proteína LT1 (LASARO et al., 2009) com o uso dos iniciadores $F w N d e I$ e $R v X h o I$. O produto de amplificação de tamanho aproximado de $450 \mathrm{pb}$ foi subclonado no vetor pGEM e subsequentemente clonado no vetor final pET22b (Figura 5A). O rastreamento dos plasmídeos recombinantes foi feito por digestão enzimática e a confirmação da obtenção do plasmídeo pET22b-LT1-B foi realizada por sequenciamento utilizando o software SeqMan para análise dos cromatogramas gerados (Laser Gene package, DNASTAR) (Figura 5A e APÊNDICE).

Para análise de expressão da proteína LT1-B, foi realizado um cultivo da linhagem de E. coli BL21 DE03 pLys recombinante em pequena escala na presença de $0,75 \mathrm{mM}$ de indutor IPTG por 4 horas a $37^{\circ} \mathrm{C}$. Alíquotas antes e pós-indução foram ajustadas a uma D.O. igual a 4,8 e submetidas a fervura com tampão de amostra para dissociação dos monômeros da subunidade B. Em seguida à eletroforese em gel de poliacrilamida, foi possível observar que após indução ocorre um aumento da quantidade de proteína recombinante na fração solúvel do sedimento celular, que na forma monomérica apresenta tamanho de 11,6 kDa (Figura 5B).
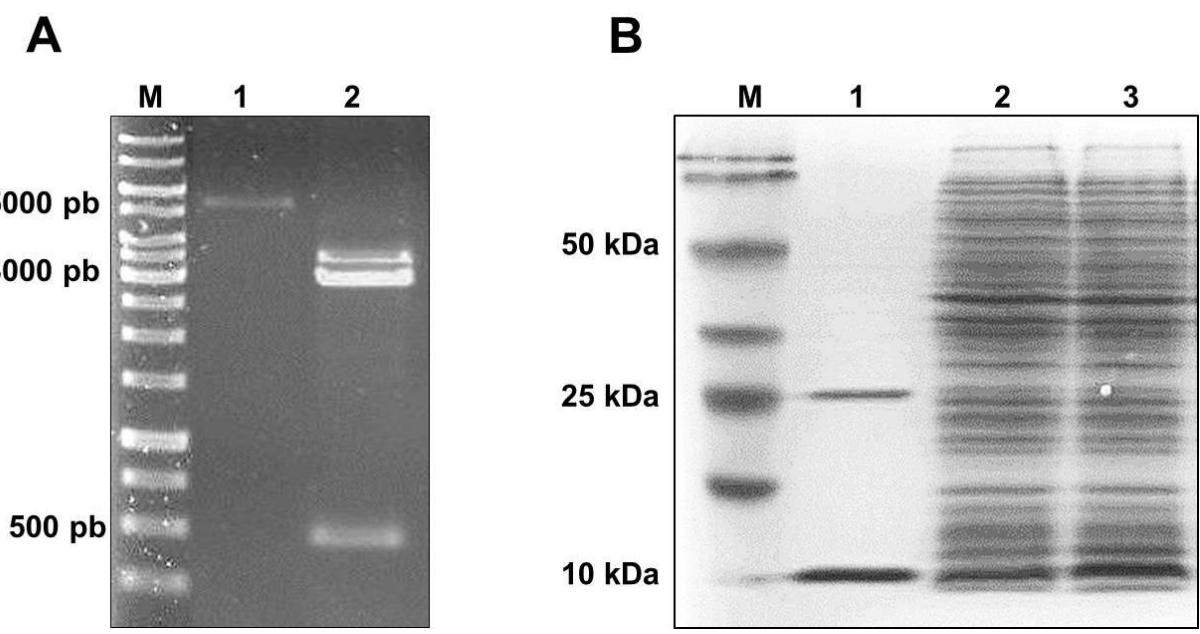

Figura 5. Clonagem do gene eltB em vetor pET22b e análise de expressão em células de $E$. coli BL21 DE3 pLys. (A) Gel de agarose 0,8 \%, M - marcador de massa molecular de $1 \mathrm{~Kb}$ (Fermentas); poço 1, plasmídeo pET22b-LT1-B nãc digerido; poço 2, pET22b-LT1-B digerido com as enzimas de restrição NdeI e XhoI. (B) Gel de poliacrilamida a 17,5 \%, M marcador de massa molecular (Fermentas); poço 1, proteína LT1 fervida; poço 2, extrato celular fervido e obtido antes da indução da proteína LT1-B; poço 3, extrato celular fervido e obtido após indução e produção da proteínaLT1-B. 


\subsection{Purificações das proteínas LT1, LT1-K63, LT1-B e EIII}

Para purificação das proteínas LT1-B, LT1 e LT1-K63, foram utilizadas cromatografias de afinidade à galactose e os cromatogramas resultantes estão apresentados nas Figuras 6A e 6D. Observamos um único pico no perfil de eluição de cada uma das proteínas purificadas. Posteriormente, analisamos o grau de pureza das proteínas obtidas aplicando-as em gel de poliacrilamida a $17,5 \%$. Foi possível verificar que todas as proteínas foram purificadas e apresentaram perfis eletroforéticos esperados para cada uma delas (Figuras 6B e 6E). Quando submetidas ao processo de fervura, as proteínas LT1 e LT1-K63 apresentaram bandas eletroforéticas correspondentes à subunidade $\mathrm{A}(27 \mathrm{kDa})$ e aos monômeros da subunidade B (11,6 kDa) e, quando não foram fervidas, demonstraram bandas eletroforéticas correspondentes à subunidade $\mathrm{A}$ e à estrutura pentamérica da subunidade $\mathrm{B}$ (55 kDa) (Figuras 6B e 6E). Em relação à proteína LT1-B, verificamos o mesmo comportamento da subunidade B das proteínas LT1 e LT1-K63 quando submetidas ou não a fervura (Figura 6B). Além disso, verificamos que a proteína LT1-B purificada foi reconhecida por anticorpos produzidos contra a proteína LT1 em ensaio de western blotting e imunodetecção, demonstrando que a proteína recombinante possui epítopos lineares correspondentes à subunidade B de LT1 (Figura 6C). No entanto, o rendimento de purificação da proteína LT1B foi bem menor, cerca de $2 \mathrm{mg} / \mathrm{L}$ de cultura, do que o obtido com as purificações das proteínas LT1 e LT1-K63, que renderam cerca de $30 \mathrm{mg}$ de proteína purificada por litro de cultura.

A proteína EIII (domínio III da proteína E do envelope do vírus da dengue) foi purificada após o processo de renaturação da estrutura proteica em 2 litros de tampão A, utilizando a técnica de diluição pulsada em velocidade de rotação e fluxo reduzidos (AMORIM et al., 2012). Após a centrifugação e filtragem do homogenato a proteína foi injetada em coluna de afinidade ao níquel. O cromatograma da purificação da proteína EIII pode ser observado na Figura 7A. O processo de eluição com imidazol resultou na formação de dois picos: o pico 01 (200 mM de imidazol), que representa os contaminantes proteicos com baixa afinidade ao níquel, e o pico 02 (700 $\mathrm{mM}$ de imidazol), que representa a proteína EIII purificada (Figura 7A). A pureza da proteína obtida foi evidenciada em gel de poliacrilamida a $17,5 \%$, onde podemos verificar que a EIII purificada migra em tamanho aproximado de $15 \mathrm{kDa}$, como esperado (Figura 7B). A EIII purificada foi adicionalmente reconhecida por anticorpos anti-EIII séricos em ensaio de ELISA (dado não mostrado). 
A

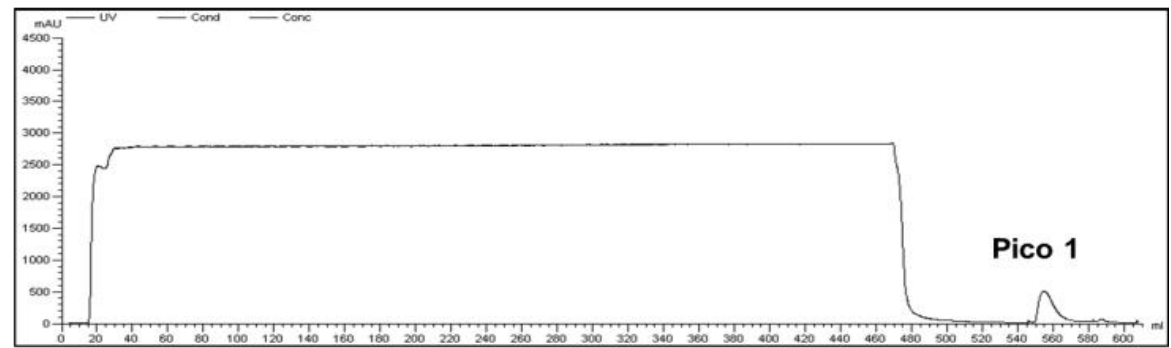

B
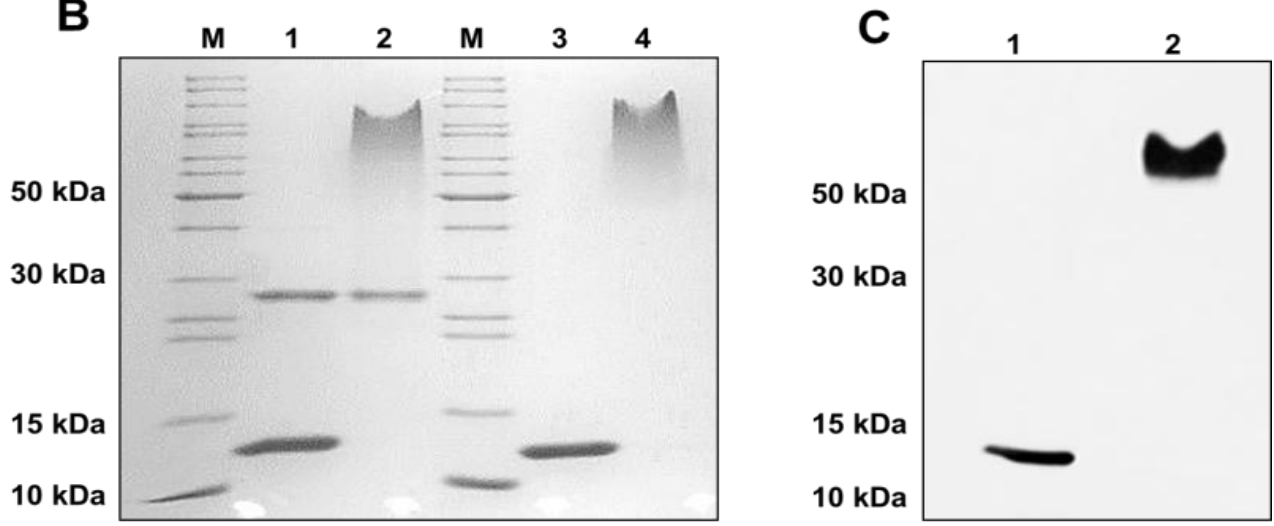

D

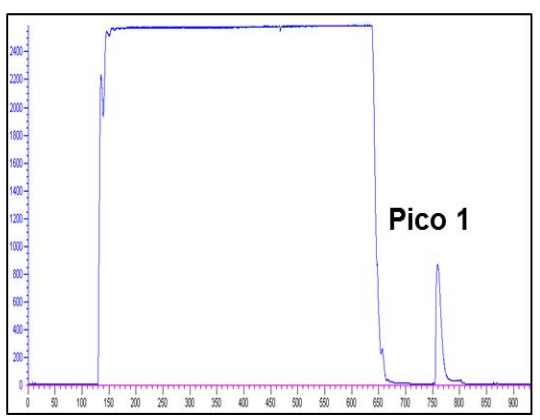

E

$\begin{array}{lllll}M & 1 & 2 & 3 & 4\end{array}$

$50 \mathrm{kDa}$

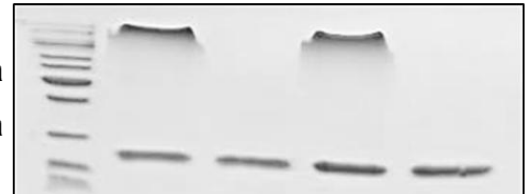

(2)

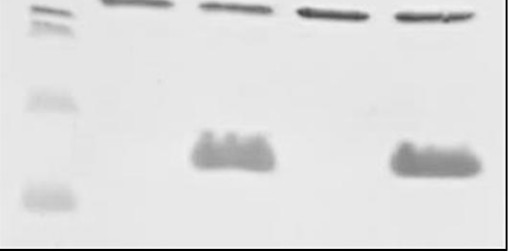

Figura 6. Purificação e caracterização das proteínas LT-1, LT1-K63 e LT1-B. (A) Cromatograma da purificação de proteína LT 1-B em coluna contendo resina de D-galactose. Pico 01 representa a eluição com 100\% de tampão TEAN acrescido de D-galactose a 0,3 M. (B) Gel de poliacrilamida a 17,5 \%, M - marcador de massa molecular (Fermentas); Amostras: poço 1, $2 \mu \mathrm{g}$ de proteína LT1 fervida (subunidade A com 27 kDa e monômeros de subunidade B com 11,6 $\mathrm{kDa}$ )como controle positivo; poço 2, $2 \mu \mathrm{g}$ de proteína LT1 não fervida (subunidade A e pentâmero de subunidade B com 55 $\mathrm{kDa}$ ) como controle positivo; poço 3, $2 \mu \mathrm{g}$ de proteína LT 1-B purificada fervida (monômeros) e poço 4, proteína LT1-B purificada não fervida (pentâmero). (C) Western-blotting e imunodetecção da proteína LT1-B com uso de anticorpos antiLT1. Amostras: poço 1, proteína LT1-B fervida (monômeros); poço 2, proteína LT1-B não fervida (pentâmero).(D) Cromatograma representativo da purificação das proteínas LT1 e LT1-K63 em coluna contendo resina de D-galactose.(E) Gel de poliacrilamida a 17,5 \% carregado com $2 \mu \mathrm{g}$ de proteína LT1 ou LT1-K63 e corado com Coomassie Blue. M marcador de massa molecular (Fermentas); poços 1-2, proteína LT1 não fervida e fervida respectivamente; poços 3-4. proteínaLT1-K63 não fervida e fervida respectivamente. 
A

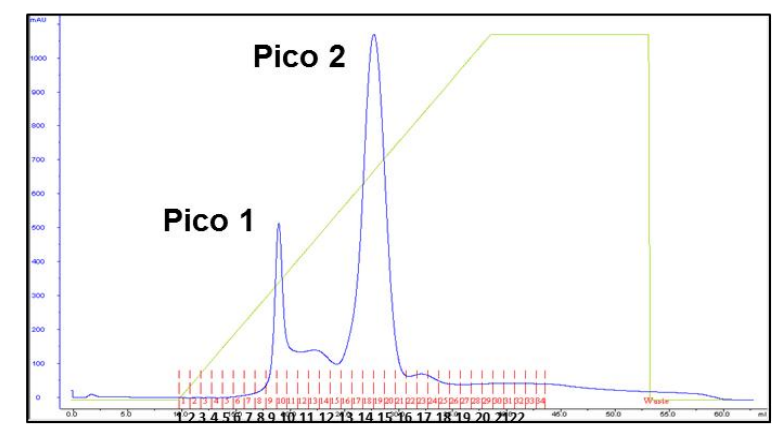

B

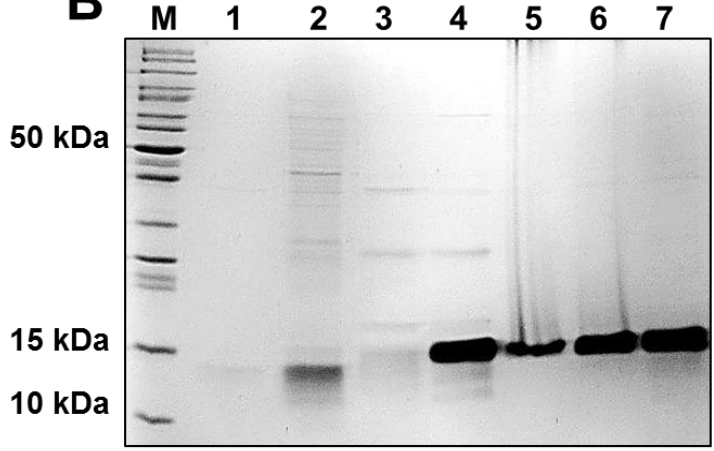

Figura 7. Purificação e caracterização da proteína EIII. (A) Cromatograma representativo da purificação da proteína EIII, onde o pico 1 (200 mM de imidazol) e pico 2 (700 mM de imidazol) representam proteínas contaminantes e proteína EIII respectivamente. (B) Gel de poliacrilamida a $17,5 \%$, apresentando a proteína EIII purificada. Gel corado com Coomassie Blue. M - marcador de massa molecular (Fermentas); poço 1 a 3, fração da eluição correspondente ao pico 1 (200 mM de imidazol); poços 4 a 6, frações da eluição correspondentes ao pico 2 (700 mM de imidazol); poço 7, proteína EIII purificada $(2 \mu \mathrm{g})$ correspondente ao pico 2 após diálise e concentração.

\subsection{Ensaios de imunização e titulação de anticorpos anti-EIII por ELISA}

Uma vez que obtivemos as proteínas purificadas, iniciamos as etapas de caracterização da resposta imunológica humoral contra o antígeno alvo induzida pelos adjuvantes sob avaliação. $\mathrm{O}$ ensaio de imunização foi realizado em linhagem de camundongos Balb/c fêmeas com idade entre 6 e 8 semanas, utilizando a via subcutânea. Os animais foram divididos em 6 grupos para imunização: PBS, EIII, EIII + LT1, EIII + LT1-K63, EIII + LT1-B, EIII + Alúmen. O protocolo vacinal consistiu na administração de 3 doses com intervalo de 14 dias entre as doses. O sangue foi cole tado um dia antes de cada dose e duas semanas após a última dose (Figura 8A). Após o primeiro ensaio de imunização utilizando $1 \mu \mathrm{g} / \mathrm{dose}$ de cada LT como adjuvante, verificamos que os animais inoculados com LT1-K63 ou LT1-B apresentaram baixos títulos de anticorpos IgG anti-EIII em comparação com aqueles vacinados com os demais adjuvantes, o que demonstra que a quantidade utilizada dessas proteínas não foi suficientemente capaz de potencializar a resposta de anticorpos $\operatorname{IgG}$ antígeno específico. Desta forma, uma nova imunização foi realizada utilizando uma quantidade maior de LT1-K63 e de LT1-B (quantidades equimolares de $5 \mu \mathrm{g}$ e 3,2 $\mu \mathrm{g}$ por dose, respectivamente). Verificamos que os animais imunizados com uma maior quantidade de LT1-K63 ou LT1-B foram capazes de aumentar os títulos de anticorpos IgG EIII-específicos (Figura 8B). Esse mesmo perfil foi observado em outros estudos com LT1-K63 ou LT1-B no qual, a potencialização da resposta humoral induzida pela administração desses adjuvantes é 
dependente da concentração administrada, indicando a importância da atividade enzimática para a resposta adjuvante de LT (MILLAR et al., 2001; GIULIANI et al., 1998).

A
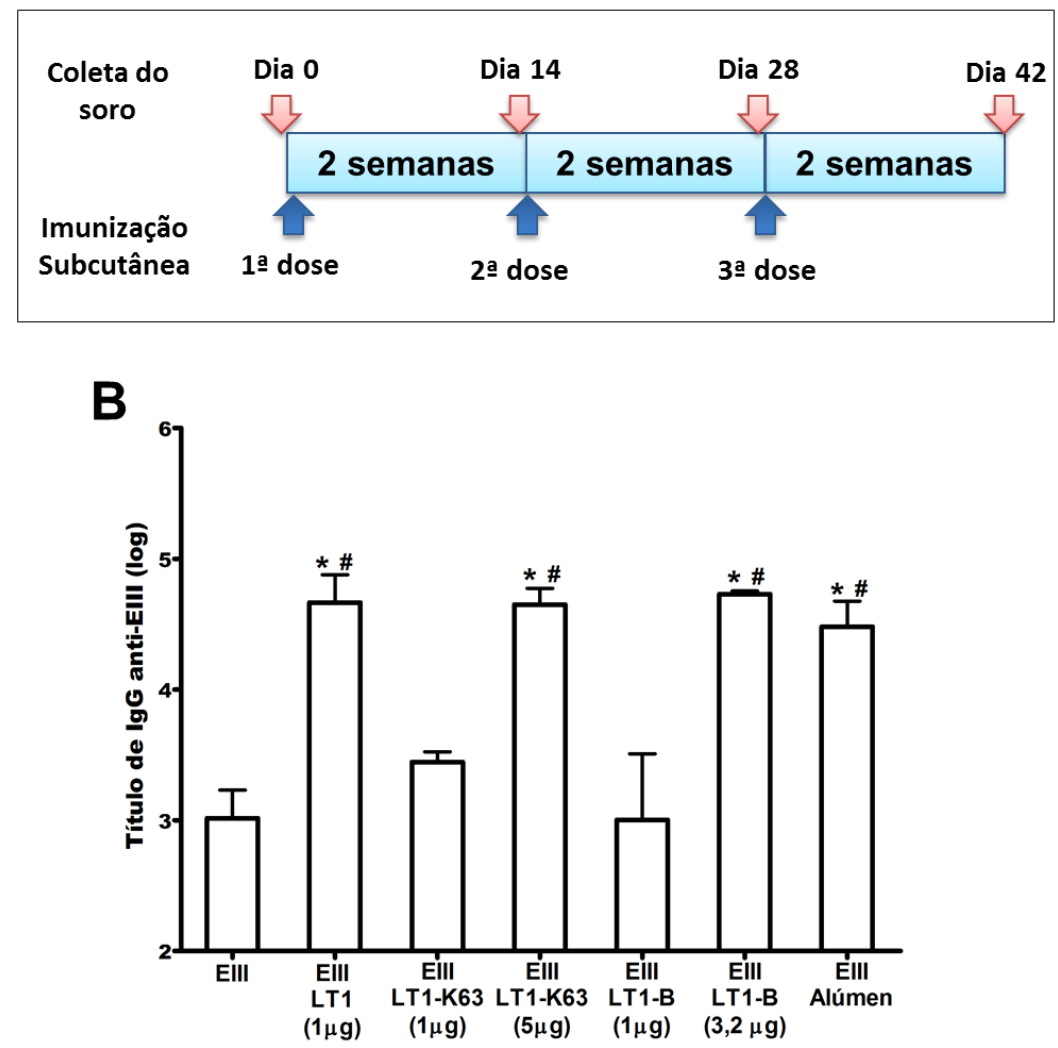

Figura 8. Esquema de imunização e análise da resposta humoral EIII-específica induzida pelos adjuvantes. (A e B) Camundongos Balb/c fêmeas foram imunizadas pela via subcutânea com 3 doses de EIII sozinha (10 $\mu \mathrm{g})$ ou EIII coadministrada a uma das LTs testadas (LT1 (1 $\mu \mathrm{g})$, LT1-K63 ( 1 ou $5 \mu \mathrm{g}$ ), LT1-B (1 ou 3,2 $\mu \mathrm{g}$ ) ou Alúmen (12,5 $\mu \mathrm{g})$. (A) Representação esquemática do protocolo de vacinação. (B) Títulos dos anticorpos IgG antiEIII encontrados nos soros dos animais imunizados após a terceira dose vacinal analisados por ELISA. Os valores dos títulos foram determinados a partir de 2 experimentos independentes com no mínimo 5 animais por grupo para as imunizações com EIII sozinha ou coadministrada a LT1 $(1 \mu \mathrm{g})$, LT1-K63 ( 1 ou $5 \mu \mathrm{g}$ ), LT1-B $(3,2 \mu \mathrm{g})$ ou Alúmen $(12,5 \mu \mathrm{g})$ e de 1 experimento com no mínimo 5 animais por grupo para a imunização com EIII coadministrada a LT1-B $(1 \mu \mathrm{g})$. Os desvios padrões estãc mostrados no gráfico e foram calculados a partir das médias de títulos de IgG entre imunizações com EIII sozinha ou coadministrada a um dos adjuv antes, exceto para o grupo EIII+LT1-B $(1 \mu \mathrm{g})$ em que o desvio representa erro padrão entre os títulos dos IgGs obtidos dos indivíduos. As diferenças entre os grupos de imunização para os parâmetros avaliados foran determinados por ANOVA e posterior teste de comparação múltipla de Tukey's, onde * indica p < 0,05, em comparação ac grupo de animais imunizados com o antígeno sozinho, ${ }^{\#}$ indica $\mathrm{p}<0,05$, em comparação ao grupo de animais imunizados com antígeno coadministrado com LT1-K63 $(1 \mu \mathrm{g})$.

Após a determinação das quantidades a serem utilizadas de LT1-K63 e LT1-B, novas imunizações foram realizadas e a presença de anticorpos IgG total e o perfil de subclasses de IgG (IgG1 e IgG2a) anti-EIII foram avaliados. Com o intuito de verificar a influência do LPS nas formulações vacinais, as proteínas foram submetidas ao tratamento em coluna de polilisina $\varepsilon$. A concentração de endotoxina após o tratamento foi inferior a $<0,02 \mathrm{EU} / \mu \mathrm{g}$ de 
proteína e < 3,6 EU/dose (100 $\mu \mathrm{l}$ da formulação vacinal), valores estes permitidos para administração de proteínas recombinantes por via parenteral (PADMA; SINGH, 2008). As proteínas tratadas foram acompanhadas quanto à estabilidade estrutural por gel de eletroforese com 17,5 \% de poliacrilamida. Os adjuvantes LT1 e LT1-K63 apresentaram degradação da subunidade A três meses após o tratamento, contrariamente, a proteína EIII e o adjuvante LT1-B apresentaram estabilidade superior a três meses após a remoção de endotoxina. Desta forma, anterior a cada dose, as proteínas tratadas foram acompanhadas quanto ao processo de degradação, com intuito de diminuir os riscos de administração de concentrações inadequadas do antígeno e adjuvantes na formulação vacinal.

Inicialmente observamos que a administração sucessiva das vacinas resultou em aumento gradual dos títulos de anticorpos IgG anti-EIII em todos os grupos experimentais tanto nos animais imunizados com proteínas não tratadas (Figura 9A), quanto nos grupos de animais imunizados com proteínas tratadas para redução do LPS (Figura 9B). Observamos ainda que os títulos de IgM permaneceram baixos mesmo após a administração dos reforços vacinais nos grupos de animais imunizados com proteínas sem tratamento e tratadas para redução de LPS (Figura 9A e 9B). Os adjuvantes testados foram capazes de potencializar a resposta de anticorpos IgG total em comparação com os grupos de animais imunizados apenas com EIII ( $p$ > 0,05). Esse aumento da resposta humoral específica foi demonstrado tanto em animais que receberam proteínas contendo altos níveis de LPS, quanto nos animais imunizados com as proteínas tratadas (Figura 9C e 9D, respectivamente). No entanto, quando os níveis de LPS foram reduzidos a níveis aceitáveis, constatamos a diminuição dos títulos de anticorpos EIII específicos no grupo de animais imunizados com EIII coadministrada com Alúmen como adjuvante $(\mathrm{p}<0,05)$ (Figura 9D). Adicionalmente, foi possível observar que todos os grupos vacinados com ou sem adjuvantes coadministrados ao antígeno apresentaram resposta humoral anti-EIII para um perfil misto Th1/Th2. A contaminação das proteínas por LPS não afetou a modulação da resposta imunológica quando os adjuvantes foram coadministrados ao antígeno. No entanto, nos animais que receberam apenas EIII tratada para remoção de LPS houve um direcionamento da resposta mais para o perfil Th2 em comparação ao antígeno contendo LPS como contaminante (Figura 9E e 9F).

A influência do LPS na resposta induzida pela administração dos adjuvantes foi concomitantemente avaliada em animais C57BL/6 selvagens e nocautes para o receptor TLR4. Nesse ensaio, avaliamos os grupos imunizados com antígeno ou em coadministração com o adjuvante LT1 não submetida ao tratamento para redução do LPS. Nas duas linhagens de animais (C57BL/6 selvagens e TLR4 nocautes) foi possível observar um aumento na 
potência da resposta de anticorpos IgG antígeno-específico, principalmente quando administramos o antígeno com LT1 como adjuvante, e a resposta foi semelhante entre os animais C57BL/6 selvagens e os animais nocautes para TLR4 (Figura 10A e 10B). Além da potencialização dos anticorpos IgG EIII-específicos, verificamos que as respostas desencadeadas pela imunização dos camundongos C57BL/6 selvagens apresentaram perfis de subclasses de IgG indicativo de um padrão misto Th1/Th2, tendenciado para um perfil do tipo Th1 (Figura 10C), enquanto que, nos animais nocautes imunizados com EIII sozinha ou em coadministração com o adjuvante LT1, a resposta foi mista Th1/Th2 com tendência para um padrão do tipo Th2 (Figura 10D). Os animais C57BL/6 selvagem e nocaute para o receptor TLR4 que receberam a proteína EIII a demonstraram um perfil de modulação da resposta humoral semelhante aos grupos de animais Balb/c que receberam a EIII sem tratamento ou tratada para a redução de LPS, respectivamente (Figura 9E e 9F). No entanto, o perfil de modulação de resposta humoral foi diferente nos animais C57BL/6 selvagens que receberam EIII coadministrada com LT1 como adjuvante (Figura 10D) em comparação aos animais nocautes e Balb/c imunizados com proteínas não tratadas e tratadas para a redução de LPS (Figura 9E e 9F). 
A

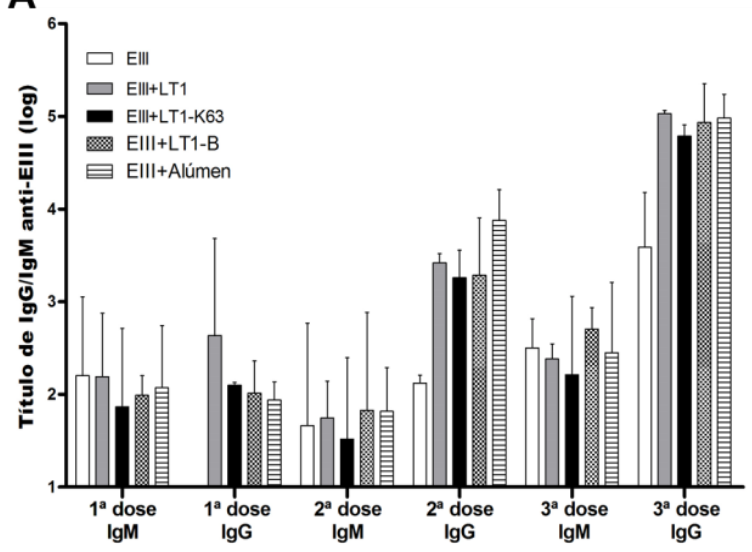

C

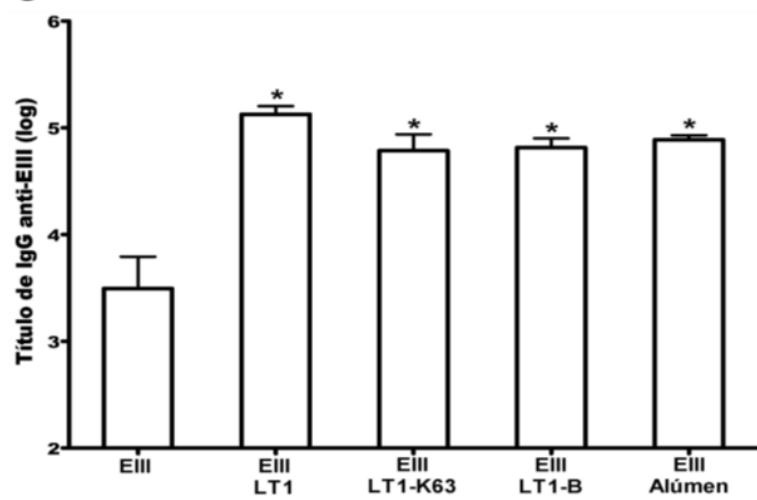

E

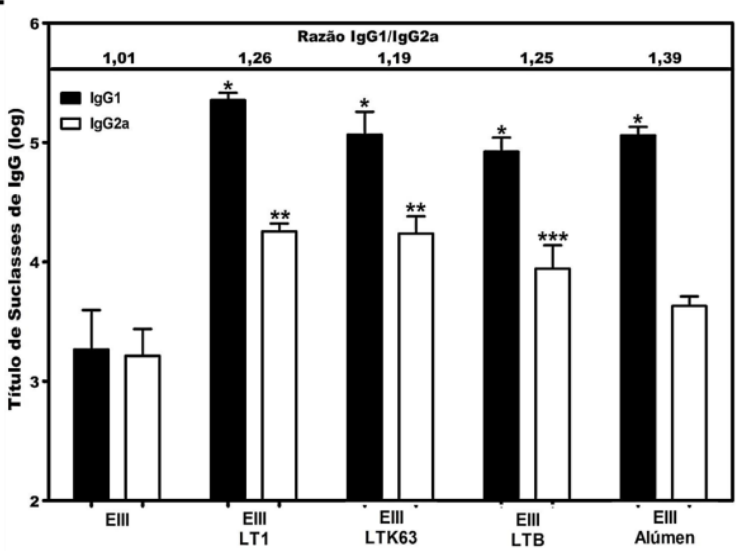

B

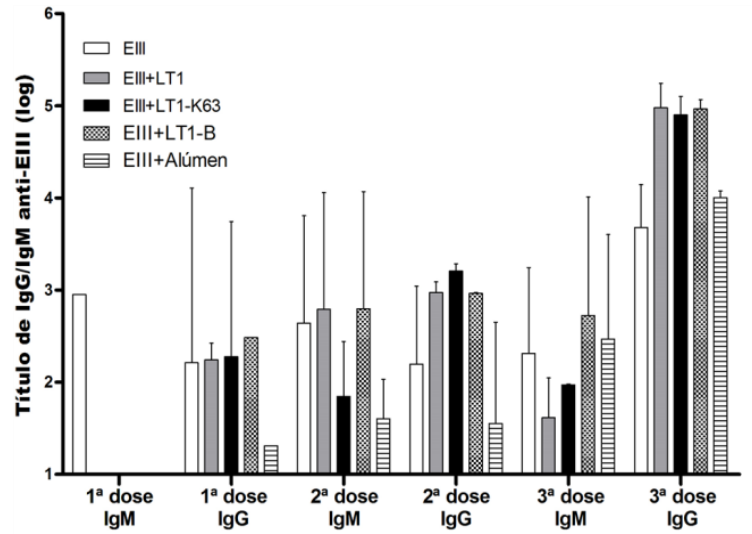

D

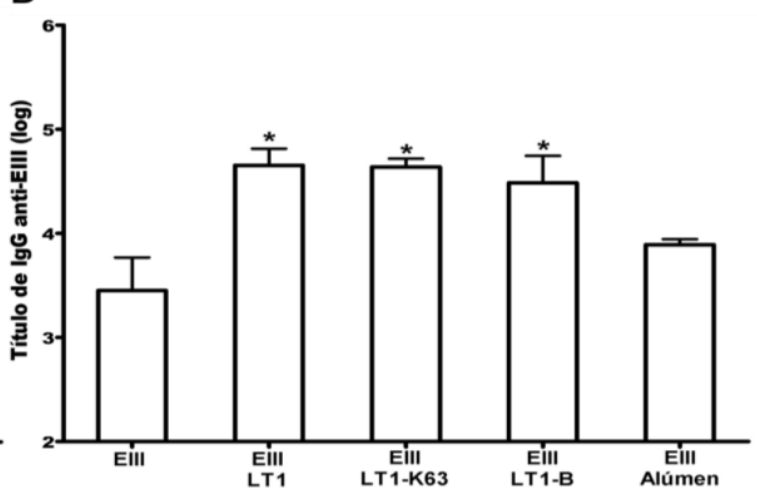

$\mathbf{F}$

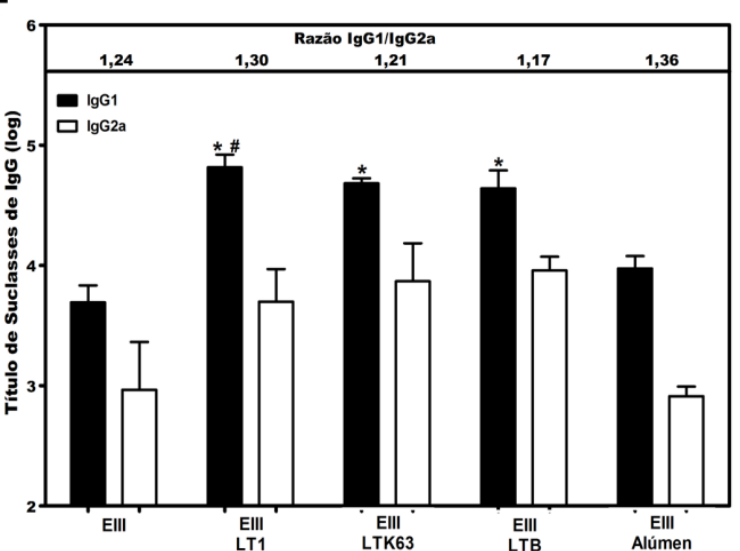

Figura 9. Análise da resposta humoral EIII-específica induzida pelos adjuvantes com proteínas não tratadas e tratadas para a remoção de LPS. (A a F) Camundongos Balb/c fêmeas foram imunizadas pela via subcutânea com 3 doses de EIII sozinha $(10 \mu \mathrm{g})$ ou EIII co-administrada a uma das LTs testadas (LT1 (1 $\mu \mathrm{g})$, LT1-K63 (5 $\mu \mathrm{g})$, LT1-B (3,2 $\mu \mathrm{g}))$ ou Alúmen $(12,5 \mu \mathrm{g})$. (A, C e E) Amostras de soros obtidos dos animais que receberam a vacina com proteínas não tratadas para remoçãc de endotoxina. (B, D, F) Amostras de soros obtidos dos animais que receberam a vacina com proteínas apresentando níveis aceitáveis de endotoxina (> 3,6 unidades endotóxicas (EU) por dose vacinal). (A e B) Títulos de anticorpos IgG e IgM anti. EIII entre cada dose do soro dos animais imunizados. (C e D) Títulos de anticorpos IgG total anti-EIII encontrados no soros dos animais após a terceira dose da vacina. (E e F) Perfil de subclasses de IgG (IgG1 e IgG2a) encontrados no soros dos animais após a terceira dose da imunização. Os valores dos títulos foram determinados a partir de 3 experimentos independentes com no mínimo 5 animais por grupo para as imunizações com EIII sozinha ou coadministrada a LT1, LT1K63 , LT1-B ou Alúmen tratadas ou não tratadas para a redução do LPS. Os desvios padrões estão mostrados nos gráficos e foram calculados a partir das médias de títulos de IgG entre imunizações com EIII sozinha ou coadministrada a um dos adjuvantes. As diferenças entre os grupos de imunização para os parâmetros avaliados foram determinados por ANOVA e posterior teste de comparação múltiplas de Tukey's, onde * indica $p<0,001$, **p $<0,01$, ***p $<0,05$, em comparação ao grupo de animais imunizados com o antígeno sozinho; onde" ${ }^{\#}$ indica p < 0,05, em comparação ao grupo de animais imunizados com antígeno coadministrado com Alúmen. 

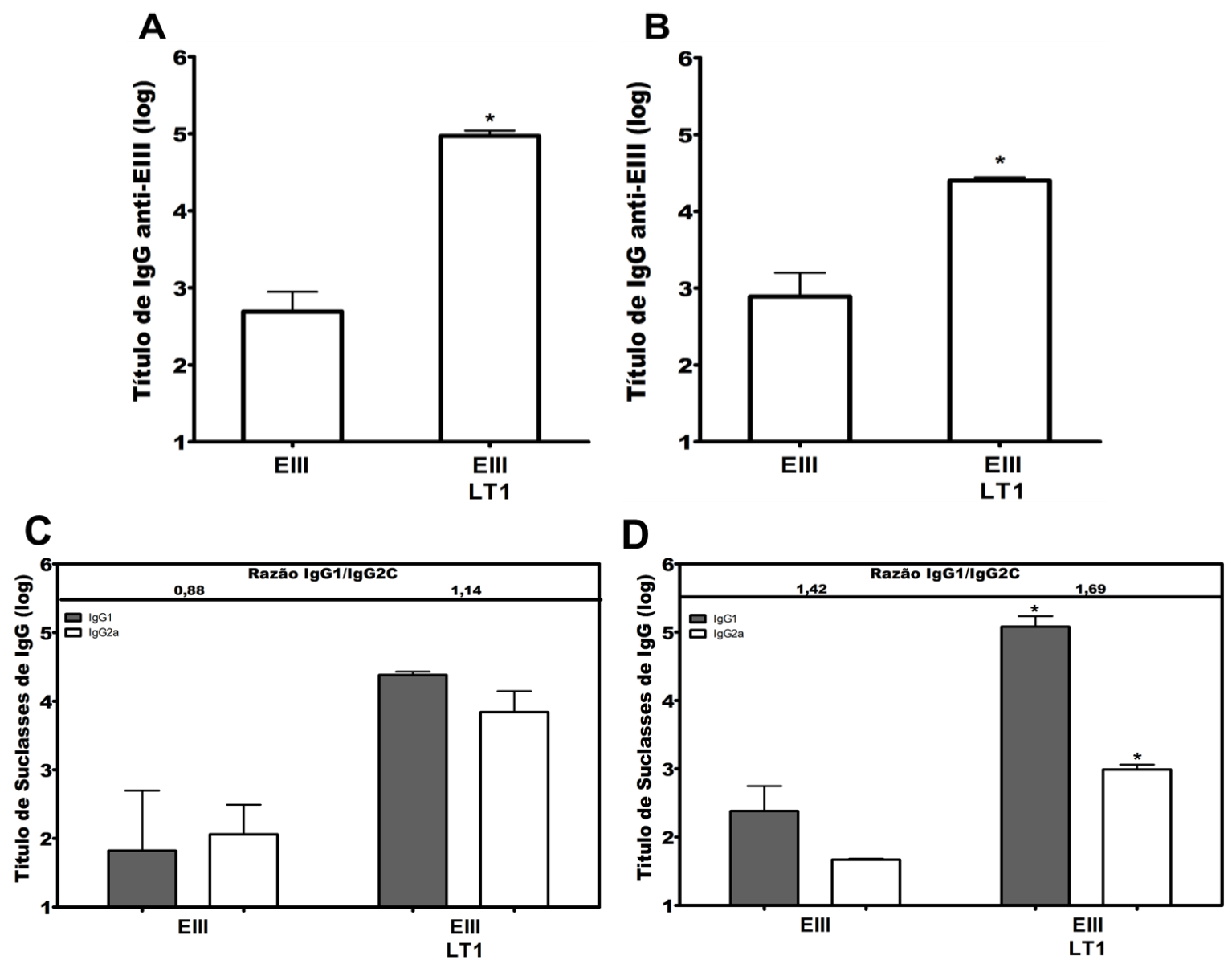

Figura 10. Análise da resposta humoral EIII-específica em animais C57BL/6 selvagens e nocautes para o receptor TLR4 após imunização com o adjuvante LT1. (A a D) Camundongos C57BL/6 fêmeas foram imunizadas pela via subcutânea com 3 doses de EIII sozinha $(10 \mu \mathrm{g})$ ou EIII co-administrada a LT1 (1 $\mu \mathrm{g})$. (A e C) Amostras de soros obtidos dos animais C57BL/6 selvagens. (B e D) Amostras de soros obtidos dos animais C57BL/6 nocautes para o receptor TLR4 Ambas as linhagens de camundongos (C57BL/6 selvagens e C57BL/6 nocautes para o receptor TLR4) foram imunizadas concomitantemente com proteínas não tratadas para remoção de endotoxina. Os valores dos títulos foram determinados a partir de 2 experimentos independentes com no mínimo 3 animais por grupo para as imunizações com EIII sozinha or coadministrada a LT1. Os desvios padrões estão mostrados nos gráficos e foram calculados a partir das médias de títulos de IgG entre imunizações com EIII sozinha ou coadministrada ao adjuvante. As diferenças entre os grupos de imunização parc os parâmetros avaliados foram determinados por Teste t e posterior teste de comparação Two-tail. * indica $\mathrm{p}<0,05$, em relação ao grupo de animais imunizados com o antígeno sozinho.

\subsection{Avaliação da afinidade e capacidade de neutralização viral dos anticorpos anti-EIII gerados após a administração da vacina com os adjuvantes}

Nessa etapa do estudo avaliamos a capacidade dos adjuvantes em melhorar a afinidade ao antígeno e a capacidade de neutralização viral. A afinidade dos anticorpos foi determinada pela concentração de tiocianato de amônio necessária para dissociar $50 \%$ da ligação do anticorpo ao antígeno (LAS ARO et al., 2009). Em ensaio utilizando proteínas não tratadas ou tratadas para a redução de LPS, não observamos diferenças na afinidade dos anticorpos ao antígeno, induzidos pela administração da EIII sozinha ou em combinação com 
os adjuvantes (Tabela 2). Demonstrando que a administração das LTs como adjuvante não aumentou a afinidade dos anticorpos anti-EIII ao antígeno. Após avaliação da afinidade dos anticorpos EIII-específicos dos animais imunizados com antígeno sozinho ou em combinação com os diferentes adjuvantes, procuramos determinar se esses anticorpos apresentam a capacidade de neutralizar a ligação das partículas virais em receptores das células LLCMK2 em ensaio in vitro. Consideramos como título neutralizante a última diluição dos soros capaz de neutralizar $50 \%$ das unidades formadoras de placas (AMORIM et al., 2012). Para este ensaio, comparamos os anticorpos obtidos de animais imunizados com proteínas não tratadas e tratadas para redução do LPS. Podemos observar que a administração apenas da proteína EIII não gerou a produção de anticorpos neutralizantes em ambos os tipos de preparações das proteínas. Dentre os animais imunizados com os diferentes adjuvantes, observamos que LT1, LT1-K63 e LT1-B foram capazes de induzir a produção de anticorpos anti-EIII com uma melhor capacidade de neutralização viral em comparação com o grupo de animais imunizados com o antígeno mais Alúmen (Tabela 2), em ambos os ensaios com proteínas sem tratamento e tratadas para redução do LPS. Ao comparar a capacidade neutralizante de anticorpos obtidos de animais imunizados com proteínas tratadas ou não para redução do LPS, verificamos que os animais imunizados com o antígeno em coadministração com LT1-B apresentou maior capacidade de neutralização viral em comparação aos demais grupos vacinais $(\mathrm{p}<0,05)$ (Tabela 2). Desta forma as LTs podem influenciar diferentemente o processo de ativação de resposta humoral, produzindo anticorpos com uma melhor capacidade neutralizante em comparação com Alúmen e com o antígeno alvo administrado sozinho. 
Tabela 3. Efeito dos adjuvantes na afinidade e neutralização dos anticorpos anti-EIII.

\begin{tabular}{lcccc}
\hline & \multicolumn{2}{c}{ Afinidade do anticorpo $^{\dagger}$} & \multicolumn{2}{c}{ Fator de Ne utralização Viral $^{*}$} \\
& Ensaio 1 & Ensaio 2 $^{* *}$ & Ensaio 1 & Ensaio 2 \\
\hline EIII & $0,44 \pm 0,088^{* * * *}$ & $0,34 \pm 0,064$ & NA $^{\#}$ & NA \\
EIII+LT1 & $0,64 \pm 0,061$ & $0,49 \pm 0,033$ & $1,81 \pm 0,370$ & 3,40 \\
EIII+LT1-K63 & $0,90 \pm 0,397$ & $0,70 \pm 0,127$ & $4,66 \pm 1,633$ & 4,23 \\
EIII+ LT1-B & $0,52 \pm 0,063$ & $0,48 \pm 0,056$ & $7,60 \pm 0,591^{\Phi}$ & 11,19 \\
EIII+ Alúmen & $0,66 \pm 0,103$ & $0,58 \pm 0,042$ & $0,84 \pm 0,090$ & 0,91 \\
\hline
\end{tabular}

Concentração molar de tiocianato de amônio requerido para dissociar 50\% dos anticorpos ligados à proteína EIII em placas de ELISA.

* Os valores representam o título mínimo do soro capaz de reduzir 50\% das UFP/título de IgG total anti-EIII X $10^{3}$.

"No ensaio 1, utilizou-se proteínas sem tratamento para remoção de LPS.

*** No ensaio 2, utilizou-se proteínas tratadas para redução de LPS em níveis aceitáveis.

**** Os desvios padrões estão mostrados na tabela e foram calculados a partir das médias entre 2 ou 3 imunizações com EIII sozinha ou coadministrada a um dos adjuvantes. Os dados para determinação do fator de neutralização no ensaio 2 foram obtidos com a realização de um único ensaio.

\#NA significa neutralização ausente.

As diferenças entre os grupos de imunização para os parâmetros avaliados foram determinados por ANOVA e posterior teste de comparação múltiplas de Tukey's, onde ${ }^{\Phi} \mathrm{p}<0,05$ em comparação aos grupos de animais que receberam a EIII sozinha ou em combinação com os adjuvantes LT1, LT1-K63 ou Alúmen.

\subsection{Obtenção de anticorpos IgG EIII-específicos}

Os dados apresentados no presente estudo mostram que os derivados de LT testados podem gerar modulação diferencial da resposta imunológica e, portanto, possivelmente poderiam influenciar os padrões de glicosilação dos anticorpos. Para analisar esse aspecto da atividade adjuvante das LTs foi preciso purificar os anticorpos anti-EIII induzidos durante as imunizações dos animais com EIII sozinha ou coadministrada aos adjuvantes. Para purificação de anticorpos EIII-específicos inicialmente foi proposto a utilização de resina $\mathrm{CNBr}$ 4B ativada (GE Healthcare) empregada para a imobilização de ligantes através dos grupamentos amina presentes na composição de uma proteína. Contudo, devido à instabilidade e precipitação constante da proteína EIII ao tampão de ligação à $\mathrm{CNBr} 4 \mathrm{~B}$, não conseguimos acoplá-la a resina e consequentemente não foi possível purificar anticorpos EIIIespecíficos dos soros dos animais imunizados. Foram empregadas várias medidas na tentativa de resolução deste problema, como variação da concentração da proteína EIII diluída em tampão de ligação e alteração do pH do tampão de ligação. No entanto, a proteína EIII continuou apresentando instabilidade e não foi possível utilizar este protocolo para purificação de anticorpos EIII-específicos.

Devido a essa dificuldade, um novo procedimento para a purificação de anticorpos EIII específicos foi adotado, utilizando o princípio da afinidade que a calda de histidina da 
proteína EIII possui pela resina de níquel. O processo de remoção dos anticorpos EIII-

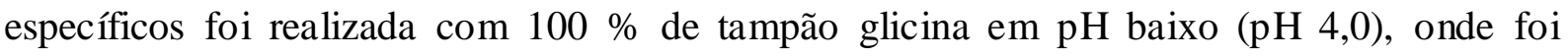
possível observar a formação de um único pico (Figura 11A). Para determinar se os anticorpos obtidos na purificação eram EIII específicos, sensibilizamos uma placa Maxisorp com proteína EIII e outra placa com extrato de E. coli BL21 DE03 pLys sem plasmídeo. Posteriormente a sensibilização, realizamos ELISA colocando soro obtido de animais imunizados com EIII+LT1 e anticorpos anti-EIII purificados desse mesmo grupo. Verificamos que, na placa sensibilizada com EIII, ambas as amostras testadas (soro e anticorpos purificados) foram capazes de reconhecer a proteína EIII, enquanto, na placa sensibilizada com o extrato bacteriano, somente a amostra de soro EIII+LT1 apresentou aumento dos títulos de IgG (Figura 11E). Desta forma, o protocolo para purificação de anticorpo utilizando a coluna de níquel com EIII imobilizada demonstrou ser uma técnica eficiente para obtenção de anticorpos EIII-específicos.

As amostras dialisadas foram submetidas a outro processo de purificação para obtenção de anticorpos EIII-específicos da classe IgG. Nesta etapa, foi utilizada coluna de proteína $\mathrm{G}$ (GE Healthcare), que possui forte afinidade à porção $\mathrm{Fc}$ dos anticorpos do tipo IgG. O processo para remoção de anticorpos da coluna foi realizado com tampão de eluição (pH 2,7), sendo possível observar o aparecimento de pico único (Figura 11B). As frações correspondentes ao pico foram reunidas e submetidas à eletroforese em gel de poliacrilamida a $12,5 \%$. Nas amostras aplicadas ao gel com tampão desnaturante é possível visualizar a presença de duas bandas correspondentes a cadeias leves e pesadas do anticorpo e naquelas aplicadas com tampão não desnaturante observa-se o aparecimento de uma única banda de peso acima de $150 \mathrm{kDa}$, que corresponde ao tamanho do anticorpo IgG inteiro (Figura 11C e 11D). No final do processo obtivemos um rendimento médio de anticorpos IgG EIIIespecíficos de aproximadamente $0,8 \mathrm{mg} /$ grupo. Tais dados demonstram a eficiência do processo de purificação padronizado para anticorpos IgG anti-EIII. 
A
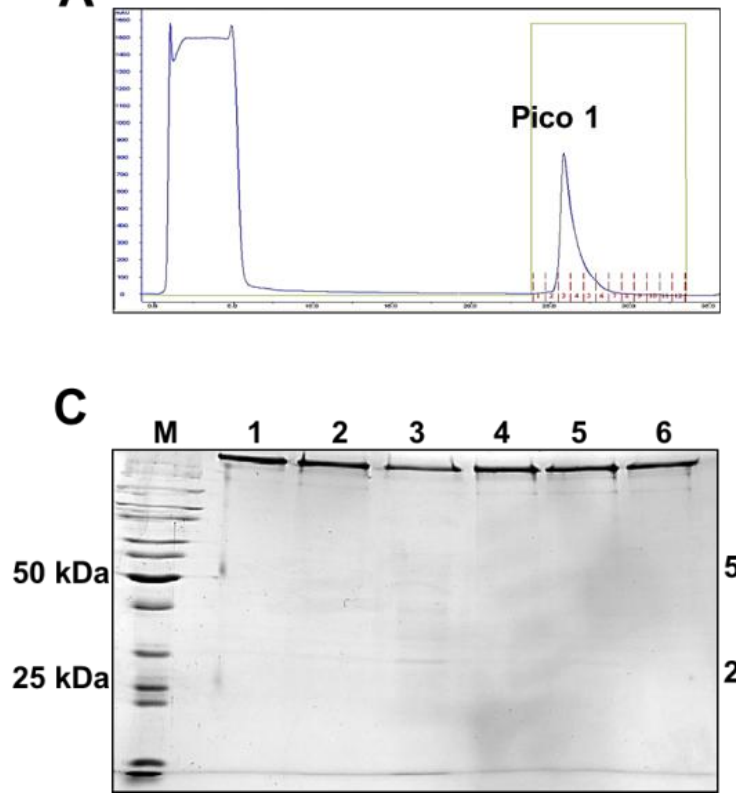

E
B

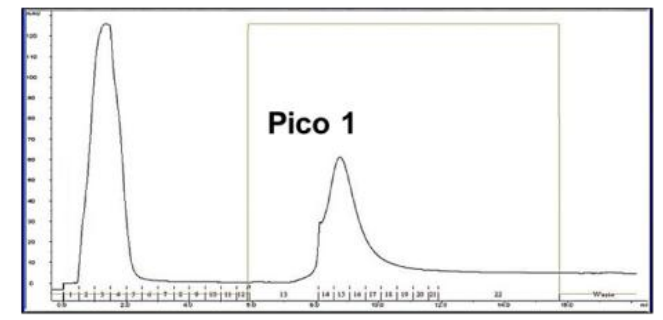

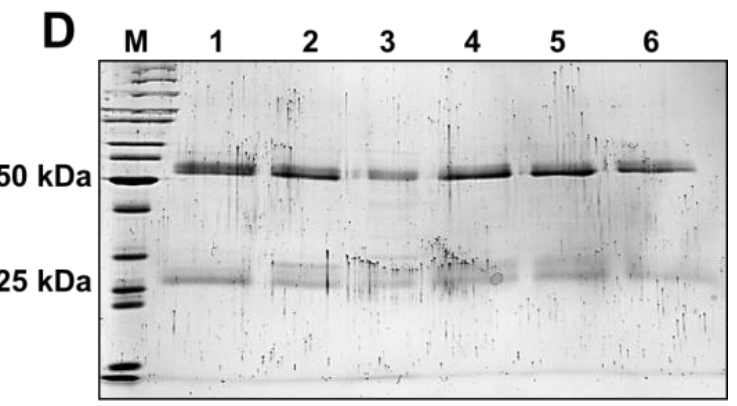

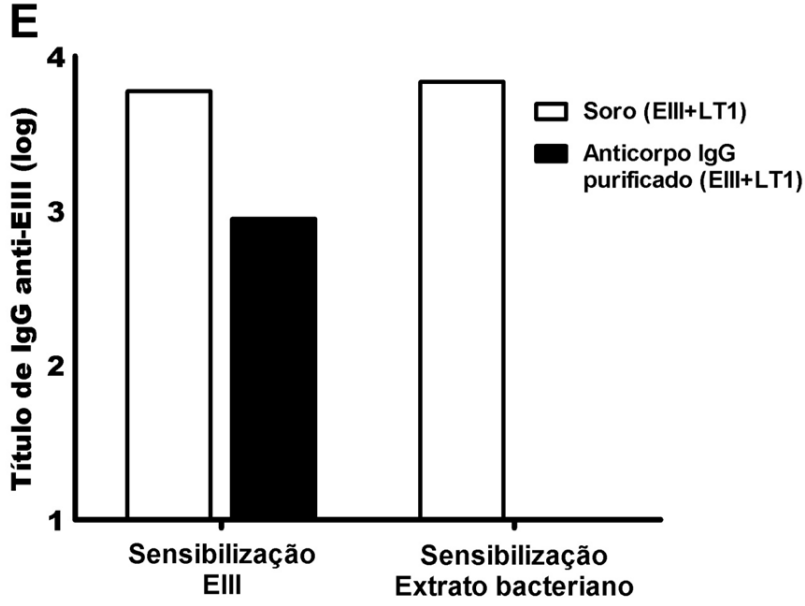

Figura 11. Purificação de anticorpos IgG EIII-específicos gerados após a imunização com EIII sozinha ou coadministrada com os adju vantes. (A) Cromatograma da purificação de anticorpos por afinidade a EIII. (B) Cromatograma da purificação de anticorpos anti-EIII da classe IgG por afinidade a proteína G. (C e D) Géis de poliacrilamida a 12,5\% corados com Coomassie Blue e carregados com anticorpos IgG EIII-específicos em condições não desnaturante (C) ou desnaturante (D). M, marcador de massa molecular; poços 1 a 6; anticorpos purificados dos grupos imunizados com PBS, EIII, EIII+LT1, EIII+LT1-K63, EIII+LT1-B ou EIII+Alúmen, respectivamente. (E) Teste da purificação de anticorpos antiEIII, obtidos em coluna de níquel com EIII imobilizada, por ELISA. Soro de animais imunizados com EIII (10 $\mu \mathrm{g})+\mathrm{LT} 1(1$ $\mu \mathrm{g})$ e anticorpos anti-EIII purificados foram submetidos a análise de títulos IgG em placa sensibilizada com a proteína EIII e placa sensibilizada com extrato bacteriano de E. coli BL21 DE03 pLys. Quantidades iguais dos soros de 5 animais foram misturados e utilizados para a purificação dos anticorpos IgG-EIII específicos, bem como para compor o soro EII+LT1. Os dados apresentados na figura são representativos de 6 experimentos.

\subsection{Deglicosilação dos anticorpos IgG EIII-específicos com endoglicosidase PNGase F}

Os anticorpos IgG EIII-específicos foram deglicosilados utilizando digestão com enzima endoglicosidase PNGase F, liberando os oligossacarídeos provenientes dos anticorpos através da hidrólise da amina presente na asparagina (Asn) na estrutura da proteína. 
Realizamos o ensaio em condições não desnaturante com intuito de manter a estrutura proteica dos anticorpos tratados. Para verificar a integridade estrutural dos anticorpos deglicosilados após o tratamento com PNGase F, as amostras foram submetidas à análise do perfil em gel de poliacrilamida em condições não desnaturante. Os anticorpos deglicosilados apresentaram uma discreta redução de tamanho em comparação com a mesma amostra de anticorpo não submetido ao tratamento enzimático como esperado (Figura 12A). Para analisar a eficiência do processo de deglicosilação, as amostras foram submetidas ao ensaio de ELISA em placa sensibilizada com $1 \mu \mathrm{g} / \mathrm{mL}$ da lectina Con A. Essa lectina tem a capacidade de reconhecer carboidratos do tipo $\alpha$-manose presente nas porções iniciais da cadeia constante de oligossacarídeos na estrutura das glicoproteínas. Os anticorpos deglicosilados apresentaram uma expressiva redução na reatividade com a lectina Con A quando comparamos com a amostra de anticorpos IgG EIII-específicos não tratados enzimaticamente, confirmando a eficiência do tratamento de deglicosilação pela enzima PNGase F (Figura 12B).

Para avaliar a capacidade dos anticorpos deglicosilados em manter o reconhecimento do antígeno, realizamos um ensaio de ELISA em placa sensibilizada com a proteína EIII, comparando-os com anticorpos dos respectivos grupos glicosilados. Como podemos observar, os anticorpos IgG EIII-específicos deglicosilados, provenientes dos grupos de animais imunizados com a proteína EIII coadministrada com os adjuvantes LT1 ou LT1-K63, aumentaram reconhecimento desses anticorpos ao antígeno em comparação com os anticorpos deglicosilados pertencentes aos outros grupos (ANOVA e pós-teste Tukey’s p < 0,05), e em comparação a todos os grupos de anticorpos glicosilados. Os anticorpos provenientes da imunização com o adjuvante LT1 apresentaram a maior absorbância entre os grupos analisados (Figura 12C e 12D). Os anticorpos glicosilados provenientes dos animais imunizados com EIII em combinação com Alúmen ou LT1-B não demostraram diferenças quanto ao perfil de ligação à EIII em comparação aos anticorpos deglicosilados dos respectivos grupos e em comparação com os anticorpos glicosilados ou deglicosilados derivados dos animais imunizados apenas com EIII ou PBS. 


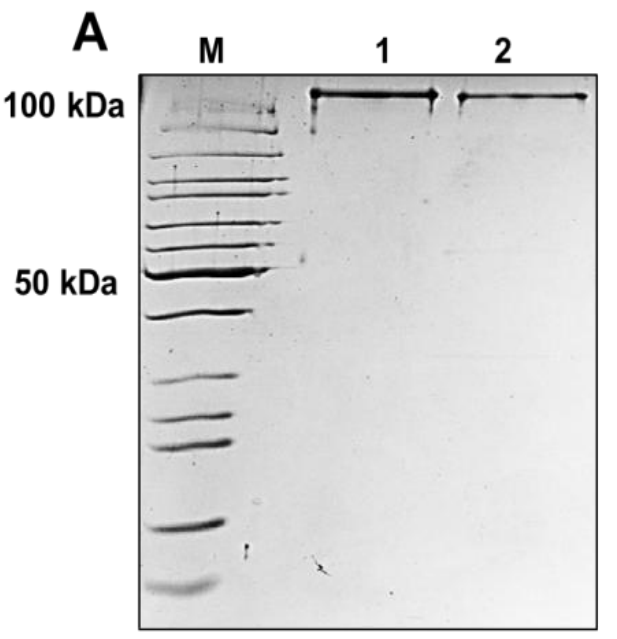

B
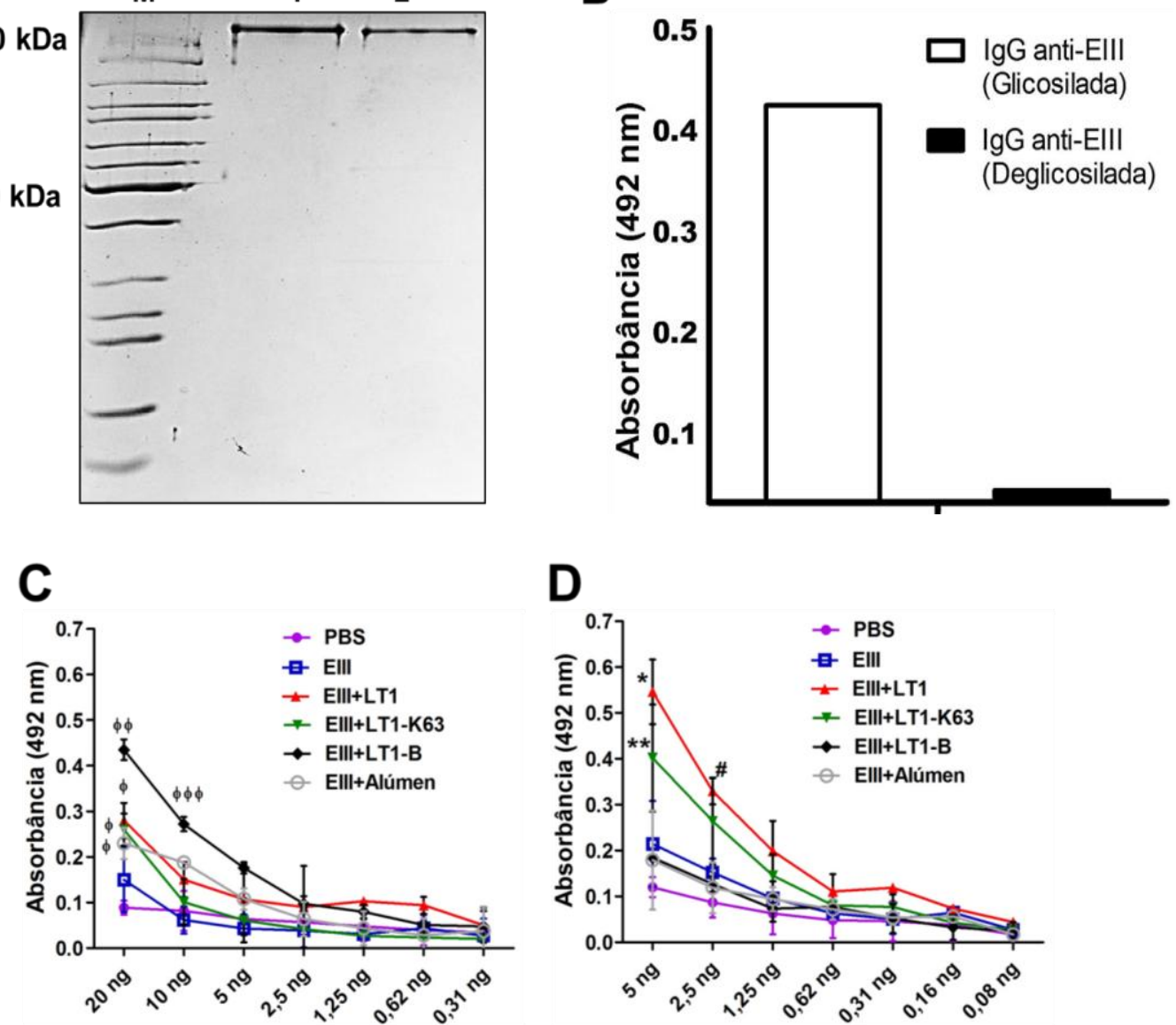

Figura 12. Caracterização dos anticorpos IgG anti-EIII deglicosilados após tratamento com enzima PNGase F. (A) Gel de poliacrilamida a 12,5\% carregado com anticorpos IgG EIII-específicos glicosilado e deglicosilado em condições não desnaturante e corado com Coomassie Blue. M, marcador de massa molecular; poços 1, anticorpo IgG anti-EIII glicosilado proveniente dos animais imunizados com EIII coadministrada com adjuvante LT1; poços 2, anticorpo IgG antiEIII deglicosilado proveniente da imunização de EIII coadministrada com adjuvante LT1. (B) Teste de eficiência do tratamento com endoglicosidase PNGase F dos anticorpos IgG antígeno específicos em ensaio de ELISA em placa sensibilizada com lectina Con A. (C e D) Anticorpos IgG EIII-específicos glicosilados e deglicosilados respectivament $\epsilon$ submetidos a ensaio de ELISA em placa sensibilizada com a proteína EIII. Ensaio realizado com anticorpos purificados e tratados com PNGase F provenientes de duas imunizações independentes. As diferenças entre os grupos de anticorpos par: os parâmetros avaliados foram determinados por ANOVA e posterior teste de comparação múltiplas de Tukey's, onde ${ }^{\phi}$ indica $\mathrm{p}<0,05$, em relação aos anticorpos glicosilados dos grupos PBS, $\Phi \Phi$ p $<0,05$ em relação aos anticorpos glicosilados dos grupos PBS, EIII, EIII+LT1, EIII+LT1-K63 e EIII+Alúmen, $\phi \phi \phi p<0,05$ em relação aos anticorpos glicosilados dos grupos PBS, EIII e EIII+LT1-K63, * indica p <0,05, em relação aos anticorpos deglicosilados dos grupos PBS, EIII, EIII+LT1-B, EIII+Alúmen, **p < 0,05 em relação aos anticorpos deglicosilados do grupo PBS, * $\mathrm{p}<0,05$, en comparação ao grupo de anticorpos deglicosilados provenientes do PBS, EIII+LT1-B e EIII+Alúmen.

\subsection{Determinação da ligação dos anticorpos IgG anti-EIII via sistema BIAcore}

Os anticorpos IgG antígeno-específicos foram submetidos à análise da capacidade de ligação ao antígeno utilizando a técnica de ressonância plasmônica de superfície (SPR) em aparelho BIAcore T100 (GE healthcare, Salt Lake City, Utah, USA). Neste ensaio preliminar foram realizadas duas estratégias, a primeira empregando a imobilização da proteína EIII e a 
segunda imobilizando anticorpo monoclonal anti-Fc de IgG de camundongo em chip CM5. $\mathrm{Na}$ primeira estratégia, tivemos dificuldade para realizar a regeneração da superfície do chip após a aplicação da amostra de anticorpos IgG purificados. Foram injetadas diferentes quantidades da solução de regeneração por um período maior de tempo, no entanto, não conseguimos remover o anticorpo ligado à proteína EIII. Assim, realizamos os ensaios apenas com a segunda estratégia proposta, empregando um chip contendo um anticorpo monoclonal anti-Fc imobilizado. Neste ensaio, observamos diferentes perfis de interação entre os grupos de anticorpos IgG antígeno-específicos glicosilados ao anticorpo monoclonal anti-Fc. Os anticorpos purificados IgG anti-EIII glicosilados e provenientes dos animais imunizados com a proteína EIII em combinação com os adjuvantes LT1-K63 ou LT1-B apresentaram maior interação ao anticorpo anti-Fc em comparação com os anticorpos glicosilados obtidos dos demais grupos de imunização (Figura 13A). Contrariamente, anticorpos IgG EIII-específicos glicosilados e provenientes dos animais imunizados com o adjuvante LT1 apresentaram uma interação reduzida com anticorpo monoclonal anti-Fc em comparação aos demais grupos vacinados, incluindo aqueles inoculados com PBS e EIII sozinha (Figura 13A). Apesar dos anticorpos IgG EIII-específico glicosilados ligarem-se ao chip contendo anticorpo monoclonal anti-Fc imobilizado, não observamos afinidade ao antígeno após injetarmos a proteína EIII (Figura 13B). Ao testar os anticorpos IgG antígeno-específicos deglicosilados, verificamos ausência de interação com os monoclonais anti-Fc imobilizados ao chip (Figura 13A). Provavelmente a remoção das cadeias de carboidratos após o tratamento com a enzima PNGase F, altera os sítios necessários para o reconhecimento dos anticorpos anti-Fc monoclonais utilizados neste ensaio. Esta análise de ressonância plasmônica de superfície em aparelho BIAcore será novamente repetido, e alguns parâmetros como a interação dos anticorpos glicosilados e deglicosilados com os anticorpos monoclonal anti-Fc imobilizado no chip serão reavaliados, com intuito de determinar a melhor forma de análise da influência das cadeias de carboidratos presentes na porção Fab dos anticorpos IgG EIII-específicos na afinidade ao antígeno EIII . 

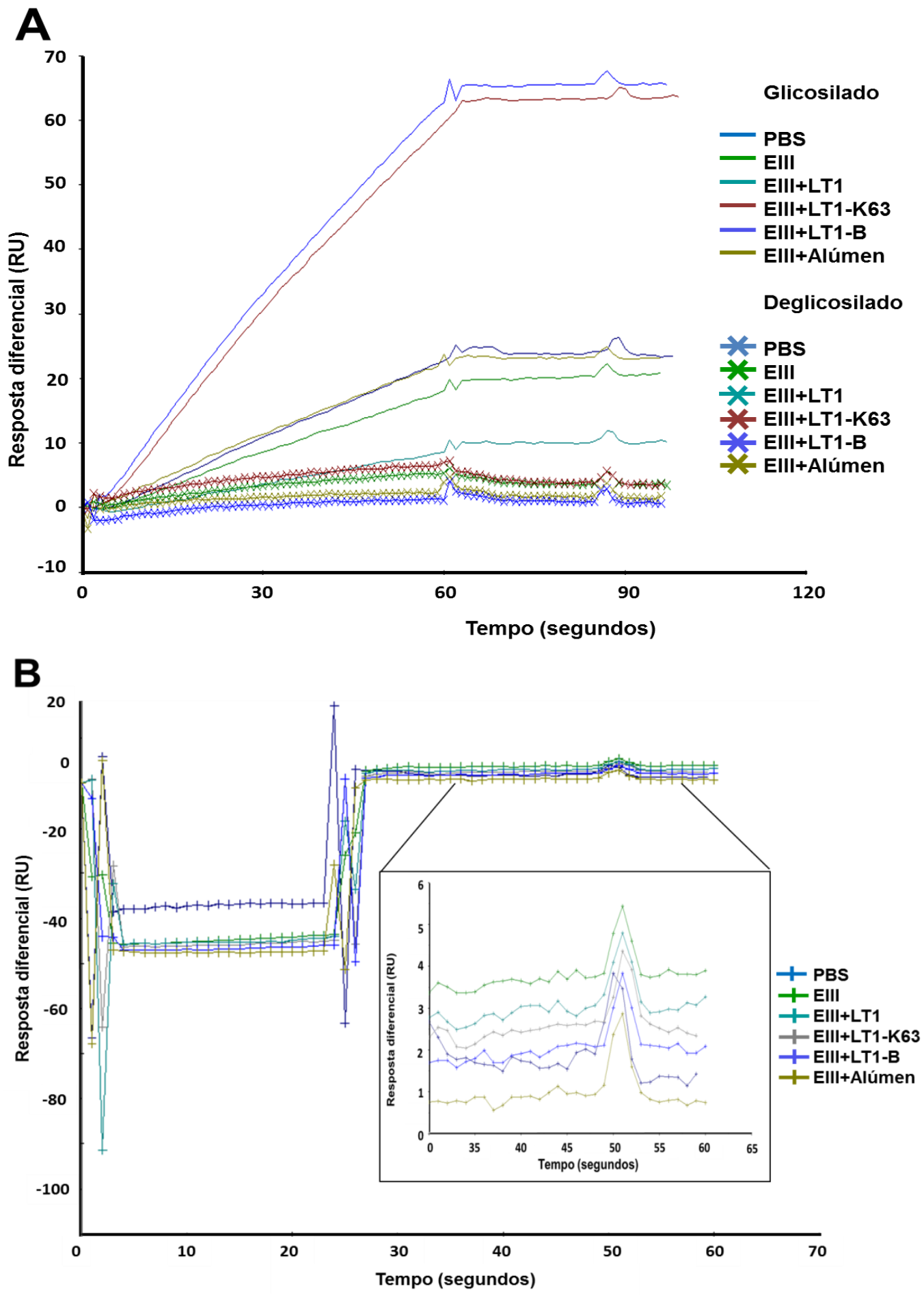

Figura 13. Determinação da afinidade dos anticorpos IgG EIII-específicos glicosilados e deglicosilados em aparelho BIAcore. (A) Avaliação da capacidade de ligação a EIII dos anticorpos IgG antígeno específicos glicosilados e deglicosilados em superfície do chip CM5 previamente imobilizado com anticorpo monoclonal anti-Fc de IgG de camundongo. (B) Determinação da afinidade dos anticorpos IgG antígeno-específicos glicosilados a EIII em chip CM5 apresentando anticorpo monoclonal anti-Fc imobilizado. A resposta diferencial está relacionada à unidade de ressonância (RU) obtida no chip teste descontada da RU obtida no chip controle, sendo proporcional a concentração de moléculas presentes na superfície do chip. Os dados representados foram obtidos em apenas um único experimento. 


\subsection{Caracterização do padrão de glicosilação dos anticorpos IgG EIII-específicos por ELISA com lectinas}

Os anticorpos IgG EIII-específicos provenientes de animais imunizados com proteínas não tratadas e tratadas para a redução de LPS foram analisados quanto a presença de perfil de glicosilação por ensaio de ELIS A em placa sensibilizada com $1 \mu \mathrm{g} / \mathrm{mL}$ de diferentes lectinas: Aleuria aurantia, Lens culinaris, Maackia amurensis, Wisteria floribunda, Erythrina cristagalli, Ricinus communis Agglutinin, Concanavalin A, Ulex europaeus, Sambucus nigra, Bauhinia purpúrea e Limulus polyphemus, que possuem afinidade por carboidratos do tipo $\alpha$ 1-3 fucose, $\alpha \mathrm{D}$-manose, $\alpha$-3 ácido siálico, $\beta 3$-6 galactose, D-manose, $\beta 1-4$ galactose, $\alpha$ manose, $\alpha 1$-fucose, $\alpha 2-6$ ácido siálico, $\beta 1$-galactose e $\mathrm{N}$-acetilmurâmico, respectivamente. Observamos que os anticorpos produzidos pelos diferentes grupos de imunização possuem diferentes padrões de glicosilação em sua estrutura (Figuras 14 e 15). Nos ensaios empregando anticorpos obtidos de animais imunizados com proteínas não tratadas e tratadas para a redução de LPS, observamos a prese nça dos padrões ácido siálico, fucose, manose e galactose na estrutura dos anticorpos IgG EIII-específicos purificados e verificamos uma diferença na distribuição destes carboidratos entre os anticorpos IgG antígeno-especifico analisados. Analisando o ensaio com proteína não tratadas para LPS, as cadeias de carboidratos nos anticorpos apresentaram entre os grupos proporcionalmente ácido siálico nos anticorpos IgG EIII-específicos purificados dos grupos de animais imunizados com os adjuvantes LT1 e LT1-K63, fucose e manose nos anticorpos proveniente da administração de LT1-B, e manose nos anticorpos obtidos dos animais que receberam a proteína EIII sozinha ou EIII em combinação com Alúmen (Figura 14). Verificamos a presença de cadeias de carboidratos contendo $\mathrm{N}$-acetilglicosamina e $\mathrm{N}$-acetilmurâmico, no entanto apresentaram menor proporção nos grupos analisados. Já os anticorpos obtidos de animais imunizados com proteínas contendo níveis aceitáveis de LPS observamos cadeias de carboidratos não apresentando diferenças na proporção, mas verificamos que entre os grupos a presença de ácido siálico ocorre mais em anticorpos IgG anti-EIII purificados proveniente do animais imunizados com EIII sozinha ou em combinação com Alúmen como adjuvante, fucose em anticorpos IgG antígeno-específico obtidos dos animais imunizados com LT1, LT1-K63 ou LT1-B como adjuvante, galactose em anticorpos IgG purificados dos animais imunizados com LT1-K63 e manose presentes no grupos de anticorpos IgG EIII-específicos proveniente da imunização com LT1 ou LT1-B como adjuvante (Figura 15). Este ensaio de ELISA com lectinas nos fornece resultados referentes à qualidade das cadeias de carboidratos presentes na 
estrutura dos anticorpos IgG anti-EIII purificados e para facilitar a analise e compree nsão, apresentamos os dados relacionando a proporção dos carboidratos presentes em cada grupo dos anticorpos gerados. Vários fatores além da presença do LPS podem estar influenciando na diferença na distribuição proporcional dos padrões de carboidratos analisados entre os ensaios, como por exemplo, a idade, estado de saúde e a variação hormonal dos animais, e a purificação de diferentes anticorpos IgG EIII-específicos policlonais.

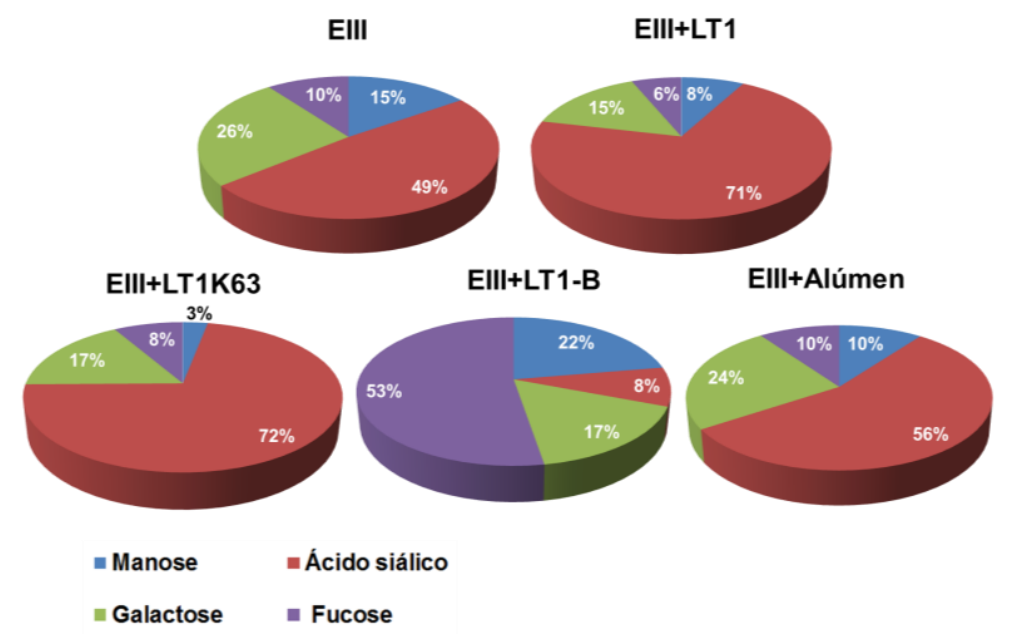

Figura 14. Análise dos diferentes perfis de glicosilação em anticorpos IgG EIII-específicos obtidos dos animais imunizados com proteínas não tratadas para redução do LPS . Os anticorpos IgG EIII-específicos purificados dos grupos imunizados com PBS, EIII, EIII+LT1, EIII+LT1-K63, EIII+LT1-B ou EIII+Alúmen, foram analisados quanto aos padrões de carboidrato por ELISA, utilizando as seguintes lectinas: Aleuria aurantia, Lens culinaris, Maackia amurensis, Wisteria floribunda, Erythrina cristagalli, Ricinus communis Agglutinin, Concanavalin A, Ulex europaeus, Sambucus nigra, e Bauhinia purpúrea. Os dados apresentados são representativos de três imunizações independentes.

EIII

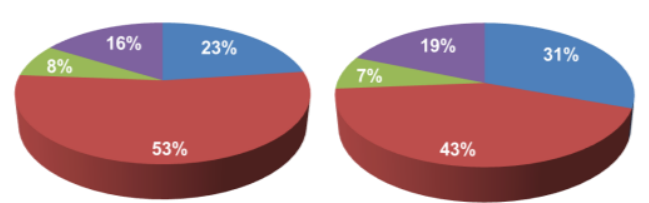

EIII+LT1-K63
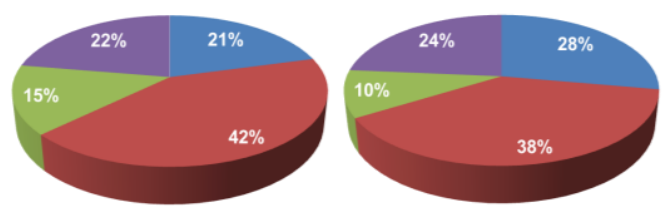

- Manose

\# Ácido siálico

malactose
Elll+Alúmen

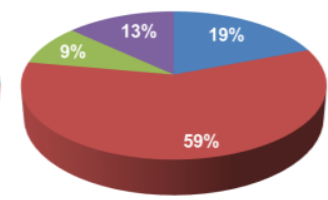

Figura 15. Análise dos diferentes perfis de glicosilação em anticorpos IgG EIII-específicos obtidos dos animais imunizados com proteínas tratadas para redução do LPS. Os anticorpos IgG EIII-específicos purificados dos grupos imunizados com PBS, EIII, EIII+LT1, EIII+LT1-K63, EIII+LT1-B ou EIII+Alúmen foram analisados quanto aos padrões de carboidrato por ELISA, utilizando as seguintes lectinas: Lens culinaris, Maackia amurensis, Erythrina cristagalli, Ulex europaeus, Sambucus nigra. Dados provenientes de duas imunizações independentes. 


\subsection{Análise do padrão de glicosilação dos anticorpos IgG EIII-específicos por espectrometria de massa em aparelho MALDI-TOF/TOF}

Com intuito de analisar as características das cadeias de carboidratos presentes na estrutura de anticorpos estudados, estes foram submetidos à desnaturação e tratamento com enzima PNGase F e, posteriormente, os carboidratos foram purificados e analisados em aparelho de espectrometria de massa MALDI-TOF/TOF, empregando a dessorção e ionização por laser UV assistida em matriz de ácido 2,5-dihidroxibenzóico (DHB). Em ensaio preliminar, observamos variação em relação à abundância relativa dos espectros obtidos por espectrometria de massa entre as amostras de anticorpos IgG antígeno-específicos estudados. Os resultados obtidos estão mostrados nas Figuras 16, 17 e 18, e apresentados de forma resumida na Tabela 4. Os anticorpos anti-EIII apresentam principalmente cadeias contendo resíduos de hexoses $(\mathrm{H})$, N-acetilglicosamina $(\mathrm{N})$, e fucose $(\mathrm{F})$. A glicoforma H3N4F1 foi encontrada em maior quantidade em relação à glicoforma H4N4F1, nos anticorpos IgG anti-EIII purificados dos grupos de animais imunizados com antígeno sozinho (Figuras 16B) ou coadminis trado com os adjuvantes LT1, LT1-K63 (Figuras 17) ou Alúmen (Figuras 18B). Observamos também que a administração do antígeno sozinho ou em combinação com LT1, LT1-K63 ou Alúmen como adjuvantes, gerou glicoformas com ausência de fucose em sua composição.

Os anticorpos purificados provenientes dos animais imunizados com EIII combinada com o adjuvante LT1-B apresentaram maior quantidade da glicoforma H4N4F1 em relação à H3N4F1 (Figuras 18A). LT1-B também induziu anticorpos com maior quantidade das glicoformas H5N4 e H5N4F1 em relação aos outros adjuvantes analisados. Verificamos ainda que a glicoforma H5N4F1A1 está presente apenas na estrutura de carboidratos dos anticorpos obtidos da administração de LT1-B (Figura 18A). Como demonstrado em nossos resultados preliminares, anticorpos IgG obtidos de animais imunizados com a proteína EIII coadministrada com adjuvante LT1-B apresentaram cadeias de carboidratos com maior abundância de resíduos de fucose e galactose em relação aos outros grupos imunização, o que possivelmente pode contribuir para indução de anticorpos IgG com capacidade antiinflamatória. Podemos perceber que o adjuvante LT1-B induziu uma maior abundancia de glicoformas nos anticorpos e, provavelmente por este motivo, observamos a presença da glicoforma contendo ácido siálico neste grupo e ausência nos anticorpos provenientes dos outros grupos de imunização. No entanto, no ensaio qualitativo em ELISA com lectinas, observamos a presença desse resíduo no perfil de glicosilação da estrutura dos anticorpos de 
todos os grupos testados. Para analisarmos a glicoformas contendo ácido siálico de anticorpos provenientes da administração dos outros adjuvantes, possivelmente devemos aumentar a concentração de anticorpos utilizados para purificação das cadeias de carboidratos e aumentar a faixa de massa a ser analisada no MALDI-TOF/TOF.

Tabela 4. Prevalência das glicoformas encontradas nos anticorpos IgG anti-EIII após imunização através da análise por MALDI-TOF/TOF.

\begin{tabular}{|c|c|c|c|c|c|c|}
\hline Glicoformas & PBS & EIII & $\begin{array}{c}\text { EIII+ } \\
\text { LT1 }\end{array}$ & $\begin{array}{c}\text { EIII+ } \\
\text { LT1-K63 }\end{array}$ & $\begin{array}{c}\text { EIII+ } \\
\text { LT1-B }\end{array}$ & $\begin{array}{c}\text { EIII+ } \\
\text { Alúmen }\end{array}$ \\
\hline H6N2 & + & ++ & ++ & + & + & - \\
\hline H3N4F1 & ++ & +++ & +++ & +++ & ++ & +++ \\
\hline H4N4 & + & + & + & ++ & ++ & + \\
\hline H7N2 & + & ++ & + & + & ++ & + \\
\hline H4N4F1 & ++ & ++ & ++ & ++ & +++ & ++ \\
\hline H5N4 & + & + & + & ++ & ++ & + \\
\hline H5N4F1 & + & + & + & ++ & +++ & + \\
\hline H5N4F1A1 & - & - & - & - & + & - \\
\hline
\end{tabular}

Nomenclatura dos resíduos: Hexoses (H) (manose e galactose); N-acetilmurâmico (N); Fucose (F); Ácido siálico (A). 

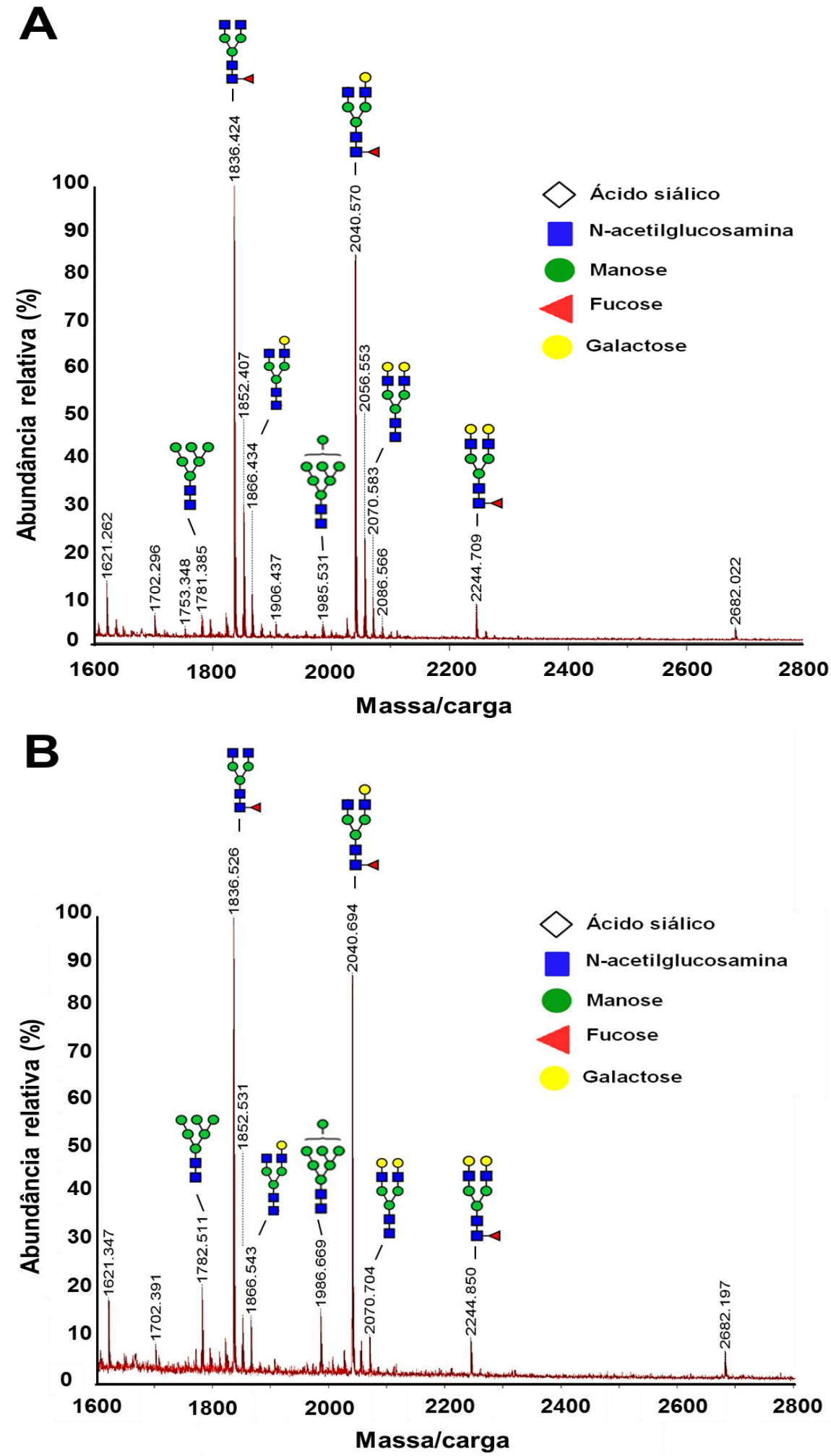

Figura 16. Análise dos diferentes perfis de glicosilação em anticorpos IgG de animais imunizados com PBS e IgG EIII-específicos dos animais imunizados com EIII sozinha por espectrometria de massa em aparelho MALDITOF/TOF. A estrutura da cadeia de carboidrato correspondente é indicada acima de cada pico, são representadas conforme recomendado pelo Consórcio para Glicoforma Funcional. (A) Cromatograma dos espectros obtidos com as cadeias de carboidratos removidos dos anticorpos IgG dos animais imunizados com PBS. (B) Cromatograma dos espectros obtidos com as cadeias de carboidratos removidos dos anticorpos IgG EIII-específicos dos animais imunizados com EIII sozinha. Nomenclatura dos resíduos: Hexoses (H) (manose e galactose); N-acetilmurâmico (N); Fucose (F); Ácido siálico (A). Cadeias encontradas: H6N2, H3N4F1, H4N4, H7N2, H4N4F1, H5N4, H5N4F1 respectivamente. Os dados de massa/carga $(\mathrm{m} / \mathrm{z})$ correspondem à massa em relação à carga do íon e abundância relativa corresponde à quantidade do íon encontrado na análise. 

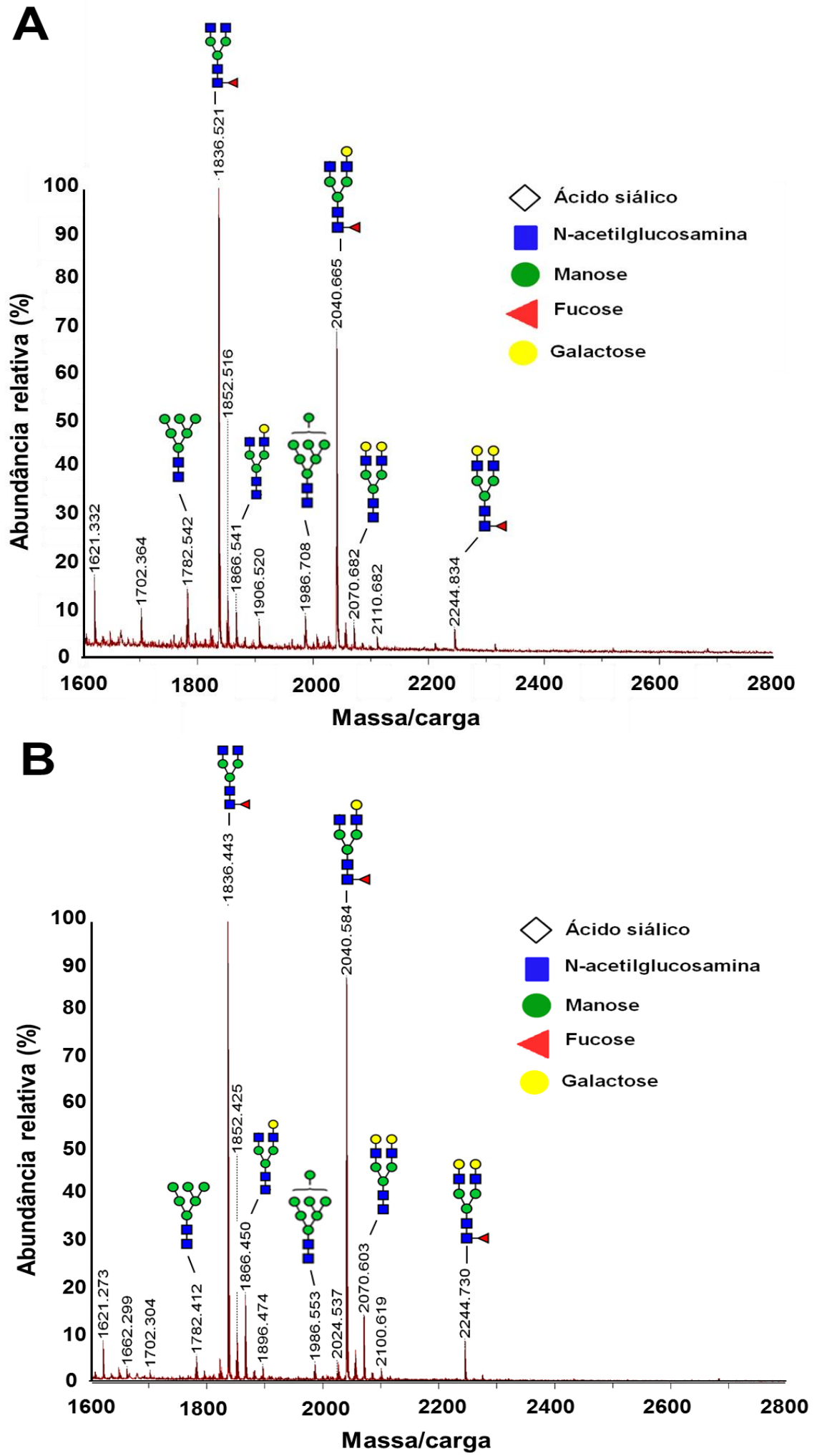

Figura 17. Análise dos diferentes perfis de glicosilação em anticorpos IgG EIII-específicos dos animais imunizados com EIII coadministrada com o adju vante LT1 ou LT1-K63 por espectrometria de massa em aparelho MALDI-TOF/TOF. A estrutura da cadeia de carboidrato correspondente é indicada acima de cada pico, são representadas conforme recomendado pelo Consórcio para Glicoforma Funcional. (A) Cromatograma dos espectros obtidos com as cadeias de carboidratos removidos dos anticorpos IgG EIII-específicos dos animais imunizados com EIII+LT1. (B) Cromatograma dos espectros obtidos com as cadeias de carboidratos removidos dos anticorpos IgG EIII-específicos dos animais imunizados com EIII +LT1-K63. Nomenclatura dos resíduos: Hexoses (H) (manose e galactose); N-acetilmurâmico (N); Fucose (F); Ácido siálico (A). Cadeias encontradas: H6N2, H3N4F1, H4N4, H7N2, H4N4F1, H5N4, H5N4F1 respectivamente. Os dados de massa/carga $(\mathrm{m} / \mathrm{z})$ correspondem à massa em relação à carga do íon e abundância relativa corresponde à quantidade do íon encontrado na análise. 

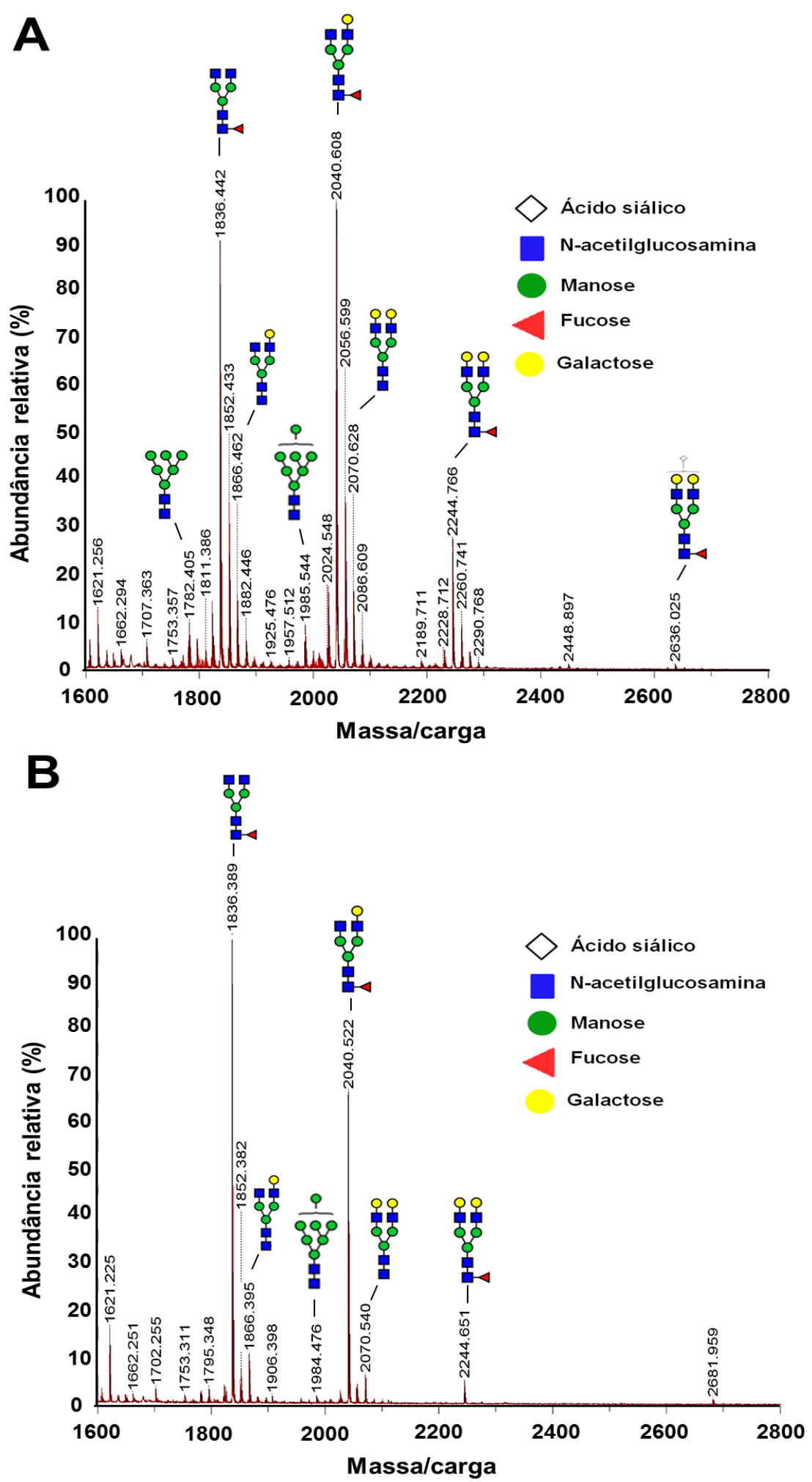

Figura 18. Análise dos diferentes perfis de glicosilação em anticorpos IgG EIIfespecíficos dos animais imunizados com EIII coadministrada com o adjuvante LT1-B ou Alúmen por espectrometria de massa em aparelho MALDITOF/TOF. A estrutura da cadeia de carboidrato correspondente é indicada acima de cada pico, são representadas conforme recomendado pelo Consórcio para Glicoforma Funcional (A) Cromatograma dos espectros obtidos com as cadeias de carboidratos removidos dos anticorpos IgG EIII-específicos dos animais imunizados com EIII+LT1-B. (B) Cromatograma dos espectros obtidos com as cadeias de carboidratos removidos dos anticorpos IgG EIII-específicos dos animais imunizados com EIII+Alúmen. Nomen clatura dos resíduos: Hexoses (H) (manose e galactose); N-acetilmurâmico (N); Fucose (F); Ácido siálico (A). Cadeias encontradas: H6N2, H3N4F1, H4N4, H7N2, H4N4F1, H5N4, H5N4F1 respectivamente. Os dados de massa/carga $(\mathrm{m} / \mathrm{z})$ correspondem à massa em relação à carga do íon e abundância relativa corresponde à quantidade do íon encontrado na análise. 


\section{DISCUSSÃO}

Neste trabalho foram levantadas questões relacionadas à capacidade dos adjuvantes LT1 e seus derivados atóxicos (LT1-K63 e LT1-B) influenciarem a qualidade da resposta imunológica humoral e induzirem diferentes perfis de glicosilação na estrutura de antico rpos IgG EIII-específicos capazes de modular a atividade efetora desses anticorpos. Observamos que a administração das LTs como adjuvantes proporcionaram a potencialização da resposta de anticorpos antígeno-específicos, modularam o perfil de subclasses de IgG e melhoraram a qualidade dos anticorpos anti-EIII gerados referente à afinidade ao antígeno e à capacidade de neutralização viral. Demonstramos ainda, de forma inédita, que esses adjuvantes foram capazes de modular diferentemente os perfis de glicosilação presentes na estrutura de anticorpos IgG EIII-específicos purificados, afetando o reconhecimento do antígeno. O conjunto de resultados dessa dissertação demonstra a eficiência das LTs como adjuvantes em melhorar a potência e a qualidade da resposta humoral gerada contra o antígeno EIII.

Para compreender a ação adjuvante das LTs sobre a resposta imunológica humoral contra a proteína EIII baseamos nossas análises no estudo de anticorpos antígeno-específicos obtidos de animais imunizados com a proteína EIII sozinha ou em combinação com adjuvantes. Nossos dados demonstraram que a presença da subunidade A enzimaticamente ativa da LT1 contribuiu para aumentar os títulos de anticorpos antígeno-específicos em comparação com os adjuvantes LT1-K63 e LT1-B quando estes foram administrados na mesma dose que LT1. No entanto, quando a quantidade de adjuvante administrada por dose de imunização dos derivados atóxicos foi aumentada observamos que a ausência da atividade enzimática da subunidade A ou mesmo a retirada desta subunidade não interferiu na potencialização das respostas de anticorpos anti-EIII geradas, demonstrando que, para imunizações feitas por via parenteral, outras regiões da subunidade A e da subunidade B são importantes para a potencialização da resposta humoral. Em ensaios demonstrados por Haan e colaboradores (1999) e Norton e colaboradores (2012), a administração da subunidade A ou da subunidade B como adjuvantes por via de mucosa foram capazes de aumentar os títulos de anticorpos antígeno-específicos em níveis semelhantes à administração da LT como adjuvante, o que corrobora nossos resultados.

A administração das LTs também contribuiu para modulação da resposta humoral, induzindo um padrão de subclasses de IgG misto (Th1/Th2) com predomínio de IgG1 sugestivo de resposta tendenciada para perfil Th2. Esse padrão de resposta já havia sido observado quando LT1 e LT1-B foram usadas como adjuvantes, entretanto, LT1-K63 tem 
normalmente promovido respostas imunológicas direcionadas para o perfil Th1 (FINGERUT et al., 2006; RYAN et al., 2000; RODRIGUES et al., 2011). O perfil de resposta observado para a LT1-K63, no entanto, pode ter sido influenciado pelo antígeno e pela dose vacinal. De fato, dados na literatura apontam que o perfil de resposta induzido por LTs pode ser influenciado pela via de administração, características do antígeno alvo e pelo tipo e quantidade do derivado de LT utilizado (HAAN et al., 1999; OLAFSDOTTIR et al., 2007; RYAN et al., 2000). Adicionalmente, nossos dados podem sugerir uma ação predominante da subunidade B na modulação da resposta humoral, embora dados na literatura apontem também para influência da subunidade A no direcionamento de perfil de resposta imunológica (NORTON et al., 2012; RYAN et al., 2000). As análises de produção de citocinas estão sendo realizadas para avaliarmos de forma mais acurada a modulação induzida pelos adjuvantes na resposta mediada por células $\mathrm{T} \mathrm{CD}^{+}$.

Além das LTs potencializarem e modularem o perfil de resposta humoral gerada nos animais imunizados, elas foram capazes de induzir características importantes para a atividade efetora dos anticorpos antígeno-específicos. As LTs, independentemente do tipo, desencadearam produção de anticorpos anti-EIII mais neutralizantes do que a EIII em combinação com Alúmen. Essa capacidade de induzir anticorpos neutralizantes já foi anteriormente demonstrada para LT em relação ao seu uso como imunógeno (Lasaro et al., 2009), no entanto apenas, no presente trabalho, foi descrita quanto à sua aplicação como adjuvante. Vale salientar que os adjuvantes LT1 tóxica e LT1-K63 induziram anticorpos menos neutralizantes em relação aos anticorpos gerados após a adminis tração da LT1-B como adjuvante. Tais diferenças nos perfis de neutralização dos anticorpos induzidos pelas LTs não foram decorrentes de alteração de afinidade ao antígeno como evidenciado nos ensaios com tiocianato de amônio e BIAcore e podem estar relacionadas a habilidade de LT1-B induzir anticorpos capazes de reconhecer diferentes epítopos importantes para a neutralização viral. No entanto, essa capacidade das LTs em induzir anticorpos direcionados a epítopos importantes para neutralização necessita ainda ser esclarecida.

Diferenças no perfil de neutralização dos anticorpos induzidos pelos derivados de LT podem ser ainda decorrentes da presença de glicosilação na porção Fab desses anticorpos. Analisando anticorpos IgG anti-EIII gerados pela administração da LT1 ou LT1-K63, verificamos um aumento na capacidade de reconhecimento ao antígeno pelos anticorpos deglicosilados em comparação aos anticorpos glicosilados do mesmo grupo. Possivelmente, as cadeias de carboidratos presentes na porção Fab desses anticorpos podem bloquear parcialmente por impedimento estérico a ligação a determinados epítopos presentes na 
superfície do antígeno, tal qual foi demonstrado por Labeta e colaboradores (1986) para alguns anticorpos monoclonais. Contrariamente, os anticorpos deglicosilados, obtidos dos animais imunizados com antígeno coadministrado com LT1-B, apresentaram redução no reconhecimento a proteína EIII em comparação aos anticorpos IgG antígeno-específicos glicosilados do mesmo grupo. Provavelmente esse adjuvante, ao contrário da LT1 e LT1-K63, induz a presença de cadeias de carboidratos capazes de melhorar a interação e neutralização viral da porção Fab dos anticorpos IgG EIII-específicos. De fato, Harmsen e colaboradores (2009) mostraram que a presença de carboidratos nas cadeias variáveis de anticorpos de lhamas aumentou a capacidade neutralizante desses anticorpos em ensaio in vitro com toxina LT e vírus da febre aftosa. Resultados apresentados no presente estudo demonstraram que a administração das LTs como adjuvante pode influenciar o tipo de cadeias de carboidratos na estrutura dos anticorpos IgG anti-EIII, no entanto, a correlação entre melhor atividade neutralizante e a presença ou ausência, bem como o perfil, de glicosilação dos anticorpos IgG EIII-específicos induzidos pelas LTs deve ser melhor esclarecida com ensaios envolvendo o uso apenas da porção Fab.

A presença ou ausência de carboidratos na estrutura dos anticorpos também afeta a funcionalidade da porção Fc dos anticorpos. Ackerman e colaboradores (2013) demostraram que remoção das cadeias de carboidratos em anticorpos IgG anti-gp120 do vírus HIV em humanos, é capaz de inibir a capacidade destes anticorpos em recrutar células NK efetoras em ensaios in vitro. Nossos dados preliminares, embora não tenham avaliado ação efetora dos anticorpos, mostram que o reconhecimento dessa porção por anticorpo monoclonal é afetada negativamente pela perda do carboidrato. Assim, observamos no ensaio de BIAcore que a glicosilação ou deglicosilação é capaz de alterar o perfil de reconhecimento dos anticorpos anti-Fc. Esse comportamento sugere que presença dessas cadeias pode influenciar a ligação dos anticorpos a receptores para Fc presentes nas células do sistema imune. A influência da glicosilação dos anticorpos IgG EIII-específicos na interação com receptores Fc necessita ser melhor investigada. Ensaio utilizando células U937 (monócitos) poderá esclarecer se estes anticorpos são capazes de direcionar a degradação do vírus dengue tipo 2 ou mediar a entrada do vírus para dentro das células proporcionando o aumento da infecção viral (ADE - antibody dependent enhancement).

Diferentes tipos de carboidratos na estrutura de anticorpos também podem influenciar o perfil de resposta imunológica gerada através da interação com componentes da resposta inata mediada por células NK, macrófagos, células dendríticas e proteínas do sistema complemento, bem como, a capacidade dos anticorpos em interagir e neutralizar os antígenos 
(ARNOLD et al., 2007; HARMSEN et al., 2009; KANECO et al., 2006; LABETA et al., 1986). Os adjuvantes testados no presente estudo induziram a presença principalmente de ácido siálico, fucose, manose e galactose nos anticorpos IgG anti-EIII sob análise qualitativa por ELISA com lectinas. Tais carboidratos têm sido correlacionados com alteração da atividade mediada pela porção Fc de anticorpos. Dentro deste contexto, Shields e colaboradores (2002) reportaram que anticorpos IgG deficientes em resíduos de fucose e alto conteúdo de ácido siálico em sua estrutura apresentam aumento na capacidade de ligação a receptores Fc $\gamma$ IIIA de seres humanos e consequentemente ocorre um aumento na citotoxidade celular mediada por anticorpos. Além da influência da cadeia de fucose e ácido siálico, outras cadeias de carboidratos demonstram interferência na atividade funcional dos anticorpos. Por exemplo, a presença de cadeias de manose e fucose nos anticorpos está relacionada a um perfil anti-inflamatório decorrente da diminuição de ligação dos anticorpos aos componentes da imunidade inata (HRISTODOROV et al., 2012; RAJU, 2008).

Análise quantitativa dos tipos de carboidratos presentes nos anticorpos anti-EIII por espectrofotometria de massa nos possibilitou a fazer inferências mais precisas sobre os perfis de glicosilação dos anticorpos induzidos pelos adjuvantes. A quantidade e o perfil de glicosilação presentes na estrutura dos anticorpos IgG antígeno-específico purificados foram distintos entre os grupos analisados. Os adjuvantes LT1, LT1-K63 e Alúmen induziram perfis de carboidratos predominantemente H3N4F1 (G0) em comparação com as glicoformas H4N4F1 (G1), H4N4 (G1), H5N4 (G2) e H5N4F1 (G2). Em alguns estudos, a ausência de galactose (G0) nas cadeias de carboidratos aumenta a capacidade dos anticorpos em ativar a via de lectina ligadora de manose do sistema complemento (HRISTODOROV et al., 2012; RAJU, 2008; SHADE; ANTHONY, 2013). Adicionalmente, esses adjuvantes diminuíram as glicoformas contendo resíd uos de fucose, o que é característico de resposta pró-inflamatória e indicativo de uma maior interação dos anticorpos com receptores FcyIIIA levando à citotoxidade celular dependente de anticorpos via células NK (SHADE; ANTHONY, 2013; SHIELDS et al., 2002; SHINKAWA et al., 2003). Observamos ainda que LT1-K63 foi capaz de aumentar a quantidade das glicoformas analisadas, mantendo o predomínio das glicoformas pró-inflamatórias. Considerando que a LT1 e LT1-K63 diferem acentuadamente quanto à indução de reação inflamatória no local de inoculação (BRAGA et al, 2014; SANTOS et al. 2011), nossos resultados demonstram que a atividade enzimática e a inflamação aguda exacerbada induzida por LT não são essenciais para o desenvolvimento de resposta adquirida humoral com caráter pro-inflamatório, o que é importante para o desenvolvimento de respostas imunes contra infecções virais e tumores. Diferentemente do 
observado para os outros adjuvantes, a LT1-B aumentou expressivamente os perfis H4N4F1 (G1) em comparação a H3N4F1 (G0), bem como promoveu o aumento das glicoformas H4N4 (G1), H5N4 (G2), H5N4F1 (G2). LT1-B induziu ainda a presença do perfil H5N4F1A1, o qual não foi encontrado nos grupos em que os demais adjuvantes foram usados. Estes resultados demonstram que subunidade B é capaz de induzir cadeias de carboidratos com um perfil anti-inflamatório nos anticorpos anti-EIII. Essa capacidade imunoregulatória da LTB foi demonstrada por Luross e colaboradores (2002), onde a administração de LTB induz a ativação de células $\mathrm{T}$ reguladoras e preveni ou trata animais com artrite reumatoide. A presença dos resíduos de galactose, além de estar relacionada à condição de saúde dos indivíduos, aumenta a afinidade dos anticorpos a receptores inibitórios Fc $\gamma$ IIB em ensaios com administração de gamaglobulina intravenosa (SHADE; ANTHONY, 2013).

Outra questão levantada foi o possível papel da contaminação com LPS das proteínas utilizadas na imunização dos animais no padrão de resposta humoral, bem como na qualidade dos anticorpos antígeno-específicos gerados pela administração das formulações vacinais. Ao compararmos as imunizações de camundongos Balb/c com proteínas não tratadas e tradadas para a redução de LPS, não observamos diferenças na potencialização ou modulação do padrão de resposta humoral induzida pela administração do antígeno em combinação com as LTs como adjuvantes. Em ensaios de imunização com animais C57BL/6 selvagens e nocautes para o receptor TLR4, não verificamos diferenças na potencialização dos anticorpos anti-EIII, no entanto observamos uma diferença na modulação do padrão de resposta humoral no grupo imunizado com antígeno e LT1. Os dados obtidos com Balb/c diferem do conjunto de dados encontrados com C57BL/6 selvagem e nocaute para TLR4 no que concerne a influência do LPS na ação imunológica de LT. Provavelmente essa distinção de comportamento se deva a diferenças de "background" genético entre as linhagens de camundongos que notadamente interfere na modulação de padrão de resposta mediado por células T CD4, direcionado a resposta mais para um perfil Th1 ou Th2 nos animais C57BL/6 e Balb/c, respectivamente (LIU et al., 2002; MILLS et al., 2000; MILLS, 2012; WATANABE et al., 2004). Vale salientar que não observamos a influência da contaminação por LPS na afinidade ao antígeno, na capacidade de neutralização viral e na presença de diferentes padrões de carboidratos na estrutura de anticorpos anti-EIII induzidos pela administração dos adjuvantes. Nenhum trabalho na literatura se propôs investigar a influência da presença de LPS na resposta humoral induzida pelas LTs administradas pela via parenteral, embora haja evidências relacionadas ao sinergismo entre LT e LPS na ativação do complexo do inflamassoma em ensaios in vitro (BRERETON et al., 2011). A ativação deste complexo está 
presente na atividade imunopotencializadora de alguns adjuvantes preconizados para uso em humanos como Alúmen e o adjuvante contendo LPS detoxificado como o AS04, mas permanece ser esclarecida sua influência na atividade adjuvante de LT in vivo.

As LTs são bastante estudadas como adjuvantes para diferentes antígenos sob distintas vias de administração vacinal. No entanto, pouco se conhece sobre os mecanismos adjuvantes exercidos pelas LTs na resposta imune humoral. A capacidade adjuvante da toxina LT1 e seus derivados atóxicos LT1-K63 e LT1-B foram avaliadas por vários grupos de pesquisa, que direcionaram seus estudos para a análise da potencialização da resposta de anticorpos IgG antígeno-específico e para a modulação do perfil de resposta humoral induzida por estes adjuvantes, mas não se preocuparam com parâmetros de funcionalidade dos anticorpos antígeno-específico gerados. $\mathrm{O}$ presente trabalho monstra diferentes propriedades imunológicas das LTs, envolvendo a capacidade desses adjuvantes de melhorar a qualidade dos anticorpos quanto à neutralização viral e à modulação de diferentes perfis de glicosilação presentes na estrutura de anticorpos IgG EIII-específicos, o que influencia as atividades efetoras desses anticorpos e, portanto, pode afetar a proteção vacinal desencadeada por adjuvantes. A habilidade de adjuvantes modular perfis de glicosilação de anticorpos é inédita e trás novas perspectivas relacionadas aos mecanismos adjuvantes das LTs envolvidos na modulação da qualidade da resposta humoral contra o antígeno. 


\section{CONCLUSÕES E PERSPECTIVAS}

A capacidade adjuvante da toxina LT1 e seus derivados atóxicos LT1-K63 e LT1-B foi avaliados por vários grupos de pesquisa que direcionaram seus estudos para a análise da potencialização da resposta de anticorpos IgG antígeno-específico e para a modulação do perfil de resposta humoral induzida por esses adjuvantes. Em nossos resultados verificamos que, além da potência e modulação da resposta humoral, a avaliação da afinidade ao antígeno e da capacidade neutralizante também se mostram como parâmetros importantes na caracterização dos efeitos adjuvantes promovidos pelas LTs. O presente trabalho demonstrou resultados inéditos sobre a capacidade das LTs em modular diferentes perfis de glicosilação presentes na estrutura de anticorpos IgG EIII-específicos, demonstrando novas abordagens para estudo dos mecanismos envolvidos na atividade desencadeada pelas LTs e outros adjuvantes.

Como continuidade deste trabalho, iremos avaliar a influência da glicosilação induzida pela administração das LTs na atividade efetora dos anticorpos IgG EIIIespecíficos. Para tal, iremos verificar se a presença ou ausência das cadeias de carboidratos pode alterar a atividade efetora ligada à porção $\mathrm{Fab}$, como a afinidade dos anticorpos IgG EIII-específicos ao antígeno e a capacidade de neutralização viral. Também pretendemos esclarecer se anticorpos IgG antígeno-específicos glicosilados e deglicosilados apresentam diferenças na interação com receptores Fc presentes em células U937, direcionado o vírus dengue tipo 2 para degradação ou mediando a entrada do vírus para dentro da célula e consequentemente favorecimento da replicação viral. 


\section{REFERÊNCIAS*}

ABBAS, A. K.; LICHTMAN, A. H. Imunologia celular e molecular. 5. ed. Rio de Janeiro: Revinter, 2005.

ACKERMAN, M. E. et al. Natural variation in Fc glycosylation of HIV-specific antibodies impacts antiviral activity. Journal of Clinical Investigation, 2013.

AMORIM, J. H. et al. Refolded dengue virus type 2 NS1 protein expressed in Escherichia coli preserves structural and immunological properties of the native protein. Journal of Virological Methods, v. 167, n. 2, p. 186-192, 2010.

AMORIM, J. H. et al. Protective immunity to DENV2 after immunization with a recombinantNS1protein using a genetically detoxified heat-labile toxin as an adjuvant. Vaccine, v. 30, v. 5, p. 837-845, 2012.

ANTHONY, R. M. et al. Novel roles for the IgG Fc glycan. Annals of the New York Academy of Sciences, p. 1-11, 2012.

ARCE, S. et al. Differential binding of Escherichia coli enterotoxins LT-IIa and LT-IIb and of cholera toxin elicits differences in apoptosis, proliferation, and activation of lymphoid cells. Infection and Immunity, v. 73, p. 2718-2727, 2005.

ARNOLD, J. N. et al. The impact of glycosylation on the biological function and structure of human immunoglobulins. Annual Review of Immunology, v. 25, p. 21-50, 2007.

AWATE, S. et al. Mechanisms of action of adjuvants. Frontiers in Immunology, v. 4, n. 114, p. 1-10, 2013.

BASSET, C. et al. Cholera-Like enterotoxins and regulatory T cells. Toxins, v. 2, p. 17741795, 2010.

BJARNARSON, S. P. et al. The adjuvant LT-K63 can restore delayed maturation of follicular dendritic cells and poor persistence of both protein- and polysaccharide-specific antibodysecreting cells in neonatal mice. Journal Immunology, v. 189, p. 1265-1273, 2012.

BÖHM, S. et al. The role of sialic acid as a modulator of the anti-inflammatory activity of IgG. Seminars in Immunopathology, v. 34, p. 443-453, 2012.

BLOMME, B. et al. Alterations of serum protein $\mathrm{N}$-glycosylation in two mouse models of chronic liver disease are hepatocyte and not B cell driven. American Journal of Physiology, v. 300, p. 833-842, 2011.

BRAGA, C. J. M. et al. Parenteral adjuvant effects of an enterotoxigenic Escherichia coli natural heat-labile toxin adjuvant. Froniers in Immunology, v. 4, n. 487, p. 1-11, 2014.

\footnotetext{
* De acordo com:

ASSOCIAÇÃO BRASILEIRA DE NORMAS TÉCNICAS. NBR 6023: informação e documentação: referências: elaboração. Rio de Janeiro, 2003.
} 
BRERETON, C. F. et al. Escherichia coli heat-labile enterotoxin promotes protective Th17 responses against infection by driving innate IL-1 and IL-23 production. The Journal of Immunology, v. 186, p. 1-11, 2011.

CARDOSA, M. J. Dengue vaccine design: issues and challenges. B ritish Medical Bulletin, v. 54 , p. $395-405,1998$.

CIUCANU, I.; KEREK, F. A simple and rapid method for the permethylation of carbohydrates. Carbohydrate Research, v. 131, p. 209-217, 1984.

COLLIN, M.; EHLERS, M. The carbohydrate switch between pathogenic and immunosuppressive antigen-specific antibodies. Experimental Dermatology, p. 1-4, 2013.

COX, E. et al. Adjuvants modulating mucosal immune responses or directing systemic responses towards the mucosa. Veterinary Research, v. 37, p. 511-539, 2006.

DI TOMMASO, A. et al. Induction of antigen-specific antibodies in vaginal secretions by using a nontoxic mutant of heat-labile enterotoxin as a mucosal adjuvant. Infection and Immunity, v. 64, p. 974-979, 1996.

DONALDSON, D. S. et al. Mucosal administration of the B subunit of E. coli heat-labile enterotoxin promotes the development of Foxp3-expressing regulatory $\mathrm{T}$ cells. Mucosal Immunology, v. 4, n. 2, p. 227-238, 2011.

EDELHOCH, H. Spectroscopic determination of tryptophan and tyrosine in proteins. Biochemistry, v. 6, p. 1948-1954, 1967.

FAN, E. et al. AB5 toxins: structures and inhibitor design. Current Opinion in Structural Biology, v. 10, p. 680-686, 2000.

FIGUEIREDO, L. T. M. Patogenia das infecções pelos vírus do dengue. Medicina de Ribeirão Preto, v. 32, p. 15-20, 1999a.

FIGUEIREDO, L. T. M. Vacinas contra dengue. Medicina de Ribeirão Preto, v. 32, p. 21$25,1999 \mathrm{~b}$.

FINGERUT, E. et al. B subunit of $E$. coli enterotoxin as adjuvant and carrier in oral and skin vaccination. Veterinary Immunology and Immunopathology, v. 112, p. 253-263, 2006.

FRASER, S. A. et al. Mutant Escherichia coli heat-labile toxin B subunit that separates toxoid-mediated signaling and immunomodulatory action from trafficking and delivery functions. Infection and Immunity, v. 71, p. 1527-1537, 2003.

FREYTAG, L. C.; CLEMENTS, J. D. Mucosal adjuvants. Vaccine, v. 23, p. 1804-1813, 2005.

FUJIHASHI, K. et al. A dilemma for mucosal vaccination: efficacy versus toxicity using enterotoxin-based adjuvants. Vaccine, v. 20, p. 2431-2438, 2002. 
GIULIANI, M. M. et al. Mucosal adjuvanticity and immunogenicity of LTR72, a novel mutant of Escherichia coli heat-labile enterotoxin with partial knockout of ADPribosyltransferase activity. Journal of Experimental Medicine, v. 187, p. 1123-1132, 1998.

GOETZE, A. M. et al. High-mannose glycans on the Fc region of therapeutic IgG antibodies increase serum clearance in humans. Glycobiology, v. 21, n. 77, p. 949-959, 2011.

GRANDOCH, M. et al. The role of Epac proteins, novel cAMP mediators, in the regulation of immune, lung and neuronal function. Journal of Pharmaceutical Sciences, v. 159, p. 265$284,2010$.

GUO, N. et al. Repeated immunization induces the increase in fucose content on antigenspecific IgG N-linked oligosaccharides. Clinical Biochemistry, v. 38, p. 149-153, 2005.

HAAN, L. et al. The role of ADP-ribosylation and GM1 binding activity in the mucosal immunogenicity and adjuvanticity of the Escherichia coli heat-labile enterotoxin and Vibrio cholera cholera toxin. Immunology and Cell Biology, v. 76, p. 270-279, 1998.

HAAN, L. et al. Mucosal immunogenicity and adjuvant activity of the recombinant A subunit of the Escherichia coli heat-labile enterotoxina. Immunology, v. 97, p. 706-713, 1999.

HAAN, L.; HIRST, T. R. Cholera toxin: a paradigm for multi-functional engagement of cellular mechanisms (Review). Molecular Membrane Biology, v. 21, p. 77-92, 2004.

HAJISHENGALLIS, G. et al. Immunomodulation with enterotoxins for the generation of secretory immunity or tolerance: applications for oral infections. Journal of Dental Research, v. 84, p. 1104-1116, 2005.

HARMSEN, M. M. et al. Enhancement of toxin- and virus-neutralizing capacity of singledomain antibody fragments by $N$-glycosylation. Applied Microbiology and Biotechnology, v. 84, p. 1087-1094, 2009.

HOLMES, E. C. RNA virus genomics: a world of possibilities. Journal of Clinical Investigation, v. 119, p. 2488-2495, 2009.

HORA, V. P. et al. Non-toxic derivatives of LT as potent adjuvants. Vaccine, v. 29, p. 15381544, 2011.

HRISTODOROV, D. et al. With or without sugar? a glycosylation of therapeutic antibodies. Lars Linden Molecular Biotechnology, 2012.

HUHN, C. et al. IgG glycosylation analysis. Proteomics, v. 9, p. 882-913, 2009.

ITOH, H. et al. The Influence of Age and Health Status on the Serum Alpha 1-Acid Glycoprotein Level of Conventional and Specific Pathogen-free Pigs. Canadian Journal of Veterinary Research, v. 57, p.74-78,1992.

JEFFERIS, R.; LUND, J. Interaction sites on human IgG-Fc for Fc gamma R: current models. Immunology Letters, v. 82, n. 1-2, p. 57-65, 2002. 
JEFFERIS, R. Glycosylation of natural and recombinant antibody molecules. Advances in Experimental Medicine and Biology, v. 564, p. 143-148, 2005.

JOHNSON, J. L. et al. The regulatory power of glycans and their binding partners in immunity. Trends in Immunology, v. 34, n. 6, p. 290-298, 2013.

KATSAMBA, P. et al. Kinectic analysis of a hight-affinity antibody/antigen interaction performed by multiple Biacore users. Analytical Biochemistry, v. 532, p. 208-221, 2006.

KATZ, J. M. et al. Adjuvant Activity of the Heat-Labile Enterotoxin from Enterotoxigenic Escherichia coli for Oral Administration of Inactivated Influenza Virus Vaccine. The Journal of Infectious Diseases, v. 175, n. 2, p. 352-363, 1997.

KANECKO, Y. et al. Anti-inflammatory activity of immunoglobulin G resulting from Fc sialylation. Sciencie, v. 313, p. 670-673, 2006.

KNUTTON, S. et al. Identification of a new fimbrial structure in enterotoxigenic Escherichia coli (ETEC) serotype $0148 \mathrm{H} 28$ which adheres to human intestinal mucosa: a potentially new human ETEC colonization factor. Infection and Immunity, v. 55, p. 86-92, 1987.

KAMMER, G. M. The adenylate cyclase-camp-protein kinase a pathway and regulation of the immune response. Immunology Today, v. 9, p. 222-229, 1988.

LABETA, M. O. et al. Structure of asymmetric non-precipitating antibody: presence of a carbohydrate residue in only one Fab region of the molecule. Immunology, v. 57, p. 311-317, 1986.

LASARO, M. A. et al. Functional and immunological characterization of a natural polymorphic variant of a heat-labile toxin (LT-I) produced by enterotoxigenic Escherichia coli (ETEC). FEMS Immunology \& Medical Microbiology, v. 55, p. 93-99, 2009.

LENCER, W. I. et al. Membrane traffic and the cellular uptake of cholera toxin. Biochimica et Biophysica Acta, v. 1450, p. 177-190, 1999.

LIU, T. et al. Differences in expression of Toll-like receptors and their reactivities in dendritic cells in BALB/c and C57BL/6 mice. Infection and Immunity, v. 70, n. 12, p. 6638-6645, 2002.

LUROSS, J. A. et al. Escherichia coli heat-labile enterotoxin B subunit prevents autoimmune arthritis through induction of regulatory CD4-T cells. American College of Rheumatology, v. 46, n. 6, p. 1671-1682, 2002.

MARTINA, B. E. E.; KORAKA, P.; OSTERHAUS, A. D. M. E. Dengue virus pathogenesis: an integrated view. Clinical Microbiology Reviews, v. 22, p. 564-581, 2009.

MCCLUSKIE, M. J. et al. Mucosal immunization of mice using CpG DNA and/or mutants of the heat-labile enterotoxin of Escherichia coli as adjuvants. Vaccine, v. 19, p. 3759-3768, 2001. 
MCKEE, A. S. et al. Alum induces innate immune responses through macrophage and mast cell sensors, but these are not required for alum to act as an adjuvant for specific immunity. Journal of Immunology, v. 7, p. 4403-4414, 2009.

MILLS, C. D. et al. M-1/M-2 macrophages and the Th1/Th2 paradigm. The Journal of Immunology, v. 164, p. 6166-6173, 2000.

MILLS, C. D. M1 and M2 Macrophages: Oracles of Health and Disease. Critical Reviews in Immunology, v. 32, n. 6, p. 463-488, 2012.

MILJAN, E. A.; BREMER, E. G. Regulation of growth factor receptor by gangliosides. Science, v. 160, p. 1-10, 2002.

MILLAR, D. G. et al. Escherichia coli heat-labile enterotoxin B subunit is a more potent mucosal adjuvant than its closely related homologue, the B subunit of cholera toxin. Infection and Immunity, v. 69, n. 5, p. 3476-3482, 2001.

MOTA, E. F.; LIMA, M. G. S.; MELO, D. F. Adjuvantes imunológicos: avanços e perspectivas. Ciência Animal Brasileira, v. 16, p. 79-88, 2006.

MURPHY, K. et al. Janeway's Immunobiology. 7. ed. Garland Science: 2008.

NASHAR, T. O. et al. Modulation of B-cell activation by the B subunit of Escherichia coli enterotoxin: receptor interaction up-regulates MHC class II, B7, CD40, CD25 and ICAM-1. Immunology, v. 91, p. 572-578, 1997.

NATARO, J. P.; KAPER, J. B. Diarrheagenic Escherichia coli. Clinical Microbiology Reviews, v. 11, p. 142-201, 1998.

NORTON, E. B. et al. The A subunit of Escherichia Coli heat-labile enterotoxin functions as a mucosal adjuvant and promotes $\operatorname{IgG} 2 \mathrm{a}$, IgA, and Th17 responses to vaccine antigens. Infection and Immunity, v. 80, n. 7, p. 2426-2435, 2012.

OLAFSDOTTIR, T. A. et al. Effects of LT-K63 and CpG2006 on phenotype and function of murine neonatal lymphoid cells. Scandinavian Journal of Immunology, v.66, p. 426-434, 2007.

PADMA, M.; SINGH, M. Endotoxin limits informations for preclinical research. Novartis Vaccine. Journal of Pharmaceutical Sciences, v. 97, n. 6, 2008.

PASHINE, A. et al. Targeting the innate immune response with improved vaccine adjuvants. Nature, v. 11, p. 63-68, 2005.

PETERS-GOLDEN, M. Putting on the Brakes: cyclic AMP as a multipronged controller of macrophage function. Science Signs, v. 2. p. 1-3, 2009.

PLOTKIN, S. A. Vaccines: past, present and future. Nature Medice, v. 11, p. 5-11, 2005.

RAPPUOLI, R. et al. Vaccines for the twenty-first century society. Nature Reviews, v. 11, p. 865-872, 2011. 
RAJU, T. S. Terminal sugars of Fc glycans influence antibody effector functions of IgGs. Current Opinion in Immunology, v. 20, p. 471-478, 2008.

RAVENEY, B. J. E. et al. The B subunit of Escherichia coli heat-labile enterotoxin inhibits Th1 but not Th17 cell responses in established experimental autoimmune uveoretinitis. Investigative Ophthalmology \& Visual Science, v. 49, n. 9, p. 4008-4017, 2008.

REED, S. G., et al. Key roles of adjuvants in modern vaccines. Nature Medicine, v. 19, n. 12, p. 1597-1608, 2013.

RESENDE, F. C. B. et al. Vaccine adjuvants: possibilities for use in humans or animals. Revista Brasileira de Alergia e Imunopatologia, v. 27, p. 116-124, 2004.

RYAN, E. J. et al. Mutants of Escherichia coli heat-labile toxin act as effective mucosal adjuvants for nasal delivery of an acellular pertussis vaccine: differential effects of the nontoxic $\mathrm{AB}$ complex and enzyme activity onTh1 and Th2 cells. Infection and Immunity, v. 67, p. 6270-6280, 1999.

RYAN, E. J. et al. Modulation of innate and acquired immune responses by Escherichia coli heat-labile toxin: distinct pro- and anti-inflammatory effects of the nontoxic AB complex and the enzyme activity. Journal of Immunology, v. 165, p. 5750-5759, 2000.

RODRIGUES, J. F. et al. Functional diversity of heat-labile toxins (LT) produced by enterotoxigenic Escherichia coli (ETEC): differential enzymatic and immunological activities of LT1 (hLT) and LT4 (pLT). Journal of Biological Chemistry, v. 286, p. 5222-5233, 2010.

SALMOND, R. J. et al. Immune modulation by the cholera-like enterotoxins. Expert Reviews in Molecular Medicine, v. 4, n. 21, p. 1-16, 2002.

SANTOS, C. M. Distinctive immunomodulatory and inflammatory properties of the Escherichia coli type II heat-labile enterotoxin LT-IIa and its B pentamer following intradermal administration. Clinical and Vaccine Immunology, v. 18, n. 8, p. 1243-1251, 2011.

SILVA, S. R. et al. Sialic Acid Residues Are Essential for the Anaphylactic Activity of Murine IgG1 Antibodies. Journal of Immunology, v. 181, p. 8308-8314, 2008.

SHADE, K. T. C.; ANTHONY, R. M. antibody glycosylation and inflammation. Antibodies, v. 2, p. 392-414, 2013.

SHIELDS, R. L. et al. Lack of fucose on human IgG1 N-linked oligosaccharide improves binding to human Fc gamma RIII and antibody-dependent cellular toxicity. Journal of Biological Chemistry, v. 30, n. 40, p. 27730-26733, 2002.

SHINKAWA, T. et al. The absence of fucose but not the presence of galactose or bisecting $N$ acetylglucosamine of human IgG1 complex-type oligosaccharides shows the critical role of enhancing antibody-dependent cellular cytotoxicity. Journal of Biological Chemistry, v. 278, n. 5, p. 3466-3473, 2003. 
SUMMERTON, N. A. et al. Toward the development of a stable, freeze-dried formulation of Helicobacter pylori killed whole cell vaccine adjuvanted with a novel mutant of Escherichia coli heat-labile toxin. Vaccine, p. 1-8, 2009.

TRUITT, R. L. et al. Glycosphingolipids as novel targets for T-Cell suppression by the B subunit of recombinant heat-labile enterotoxin. Infection and Immunity, v. 66, p. 12991308, 1998.

TRITTO, E. et al. The Acquired Immune Response to the Mucosal Adjuvant LTK63 Imprints the Mouse Lung with a Protective Signature. Journal of Immunology, v. 179, p. 5346-5357, 2007.

ZOETEWEIJ, J. P. et al. GM1 binding-deficient exotoxin is a potent non inflammatory broad spectrum intradermal immunoadjuvant. Journal of Immunology, v. 177, p. 1197-1207, 2006.

WATANABE, H. et al. Innate immune response in TH1 - AND TH2-dominant mouse strains. Shock, v. 22, n. 5, p. 460-466, 2004.

WILLIAMS, N. A. et al. Prevention of autoimmune disease due to lymphocyte modulation by the B-subunit of Escherichia coli heat-labile enterotoxin. The National Academy of Sciences of the USA, v. 94, p. 5290-5295, 1997.

WILLIAMS, N. et al. Immune modulation by the cholera-like enterotoxins: from adjuvant to therapeutic. Immunology Today, v. 20, p. 95-101, 1999.

YAMADA, E. et al. Structural changes of immunoglobulin G oligosaccharides with age in healthy human serum. Glycoconjugate Journal, v. 3, n. 14, p. 401-405, 1997. 
APENDICE - Sequenciamento do gene eltB

Alinhamento entre a sequência de nucleotídeo do gene que codifica para o gene elt $B$ obtida do gene bank (GI: 408994) e as sequência geradas por sequenciamento do gene eltB contido no vetor recombinante pET22b-LT1-B com os iniciadores FwNdeI e RvXhoI.

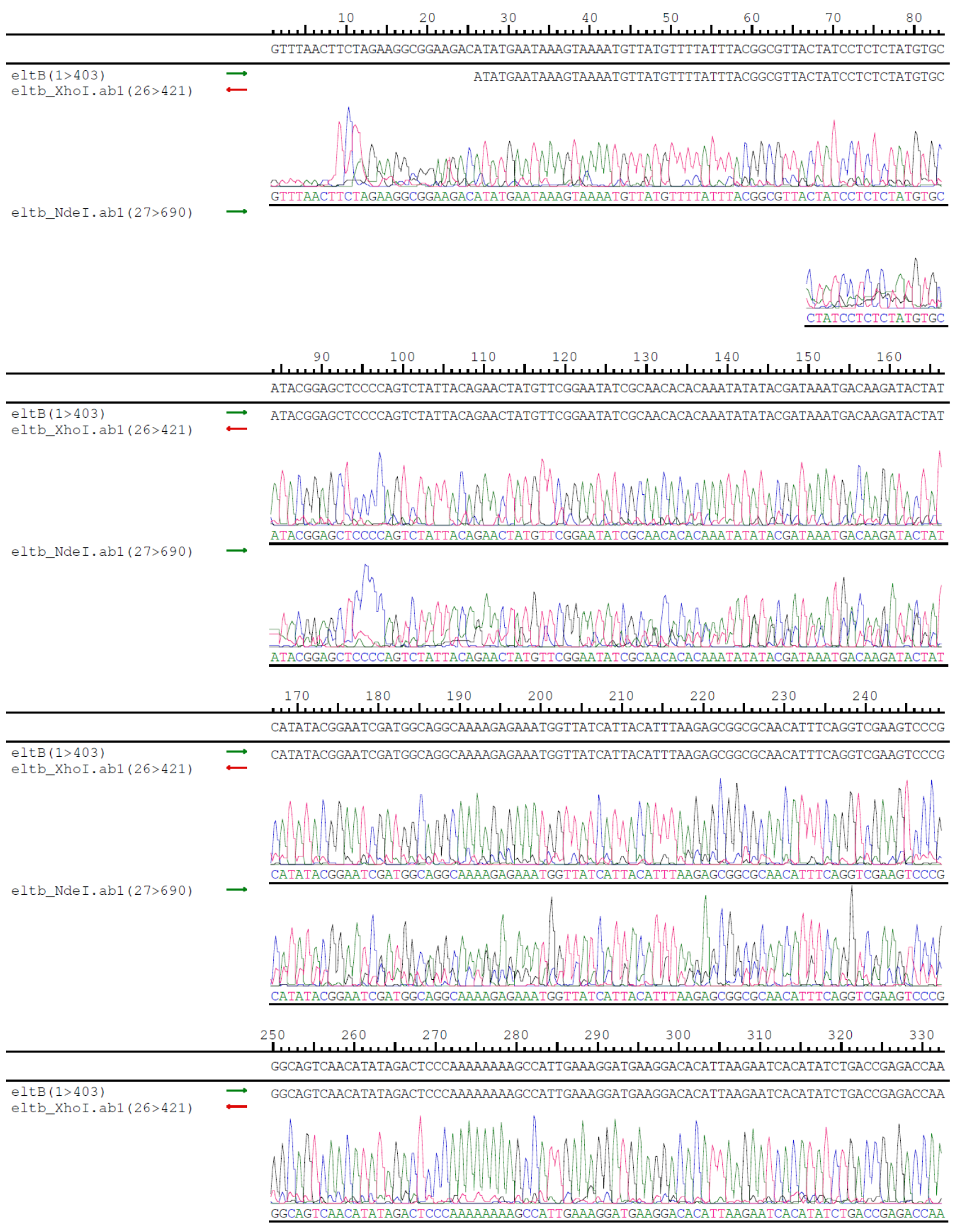



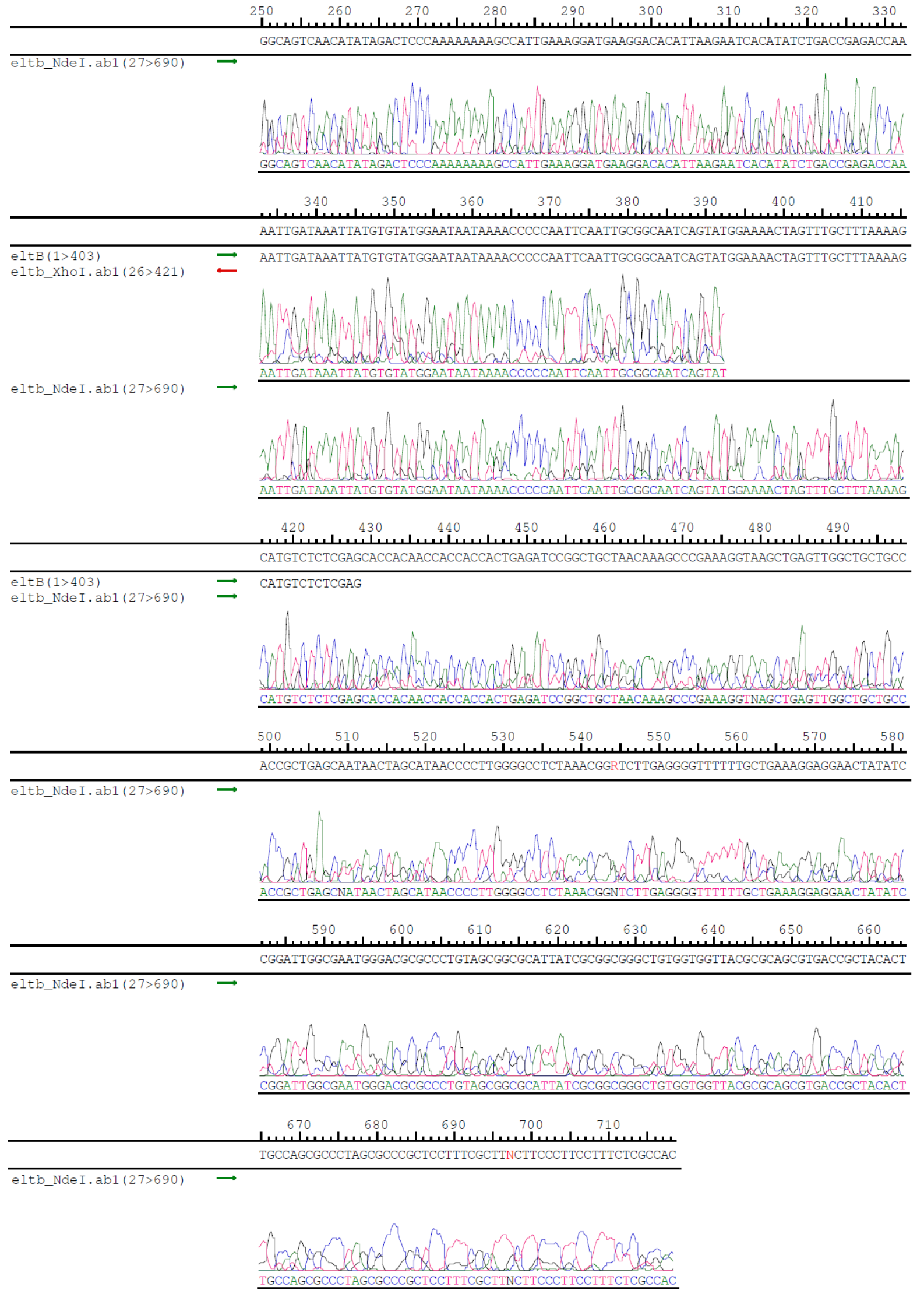